UNIVERSIDADE DE SÃO PAULO FACULDADE DE FILOSOFIA, LETRAS E CIÊNCIAS HUMANAS DEPARTAMENTO DE GEOGRAFIA

\title{
CHRISTIANE SPÖRL
}

\section{METODOLOGIA PARA ELABORAÇÃO DE MODELOS DE FRAGILIDADE AMBIENTAL UTILIZANDO REDES NEURAIS}

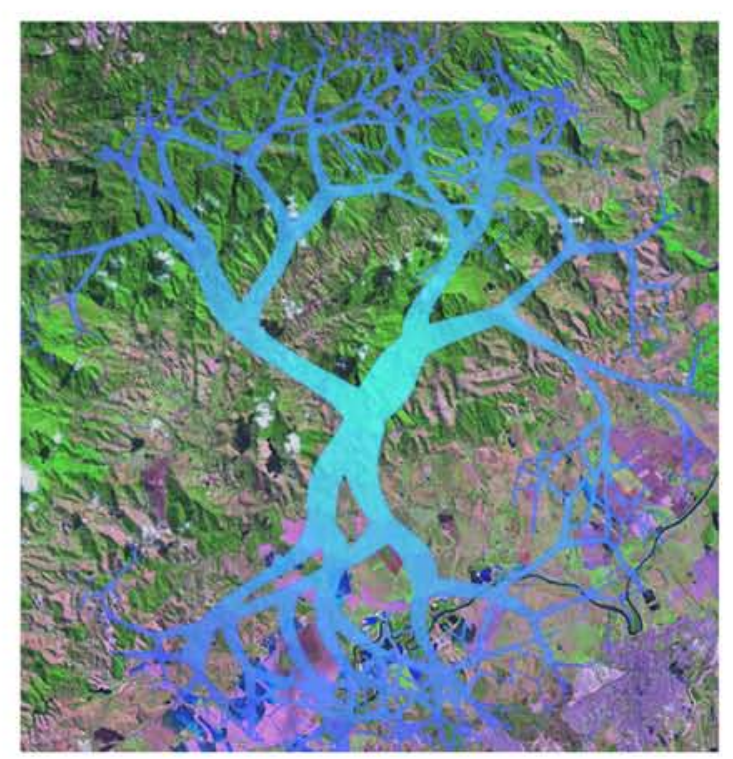




\section{CHRISTIANE SPÖRL}

\section{METODOLOGIA PARA ELABORAÇÃO DE MODELOS DE FRAGILIDADE AMBIENTAL UTILIZANDO REDES NEURAIS}

Tese de Doutorado apresentada à Faculdade de Filosofia, Letras e Ciências Humanas da Universidade de São Paulo como parte dos requisitos para obtenção do título de Doutor em Geografia.

Área de Concentração: Geografia Física

Orientador: Profo Dr. Ailton Luchiari 


\section{AGRADECIMENTOS}

É difícil mencionar todas as pessoas que de uma forma ou de outra colaboraram para a concretização desta Tese, às quais gostaria sinceramente de agradecer. Peço desculpas caso não consiga expressar, através deste agradecimento, uma homenagem adequada a vocês.

Várias pessoas estiveram envolvidas do começo ao fim nesta pesquisa, tornando-a possível. Agradeço a todos, especialmente:

Ao professor Ailton Luchiari, pela orientação, amizade e apoio demonstrados ao longo deste trabalho, indicando sempre os melhores caminhos a serem seguidos.

Aos professores e amigos Jurandyr Sanches Ross e Emerson Galvani pelos valiosos comentários e sugestões durante o Exame de Qualificação e ao longo deste trabalho.

Aos especialistas convidados, professores Ailton, Crepani, Déborah, Emerson, Marisa e Jurandyr pela infinita paciência, pois disponibilizaram algumas de suas preciosas horas para a realização de várias e várias simulações, as quais foram responsáveis pela base de dados aplicada no treinamento das Redes Neurais Artificiais. Sem a valiosa contribuição destes especialistas este trabalho não teria sido possível e nem teria credibilidade.

À Ana, Jurema, Maria e Rosângela, da Secretaria de Pós-Graduação, pela prestatividade e apoio recebidos nestes anos dedicados à pós-graduação.

Aos amigos e colegas do Departamento que através dos seus questionamentos e sugestões, muito contribuíram para o desenvolvimento deste trabalho.

À Engecorps e sua equipe, pelo apoio, confiança e pela formação profissional adquirida ao longo destes anos de trabalho. E em especial, aos engenheiros Afonso Celso Marques, Danny Dalberson e Marcos Godoi pelo incentivo, confiança, conselhos e ensinamentos.

Aos amigos Ana Paula, Andrei, Eduardo e Nelson pelos conselhos, sugestões, apoio e pelas conversas e boas risadas.

Ao Andrei Almeida, pela elaboração da capa, que ajudou, e muito, no momento da grande da correria para finalizar essa tese.

Ao CNPQ pela concessão da bolsa de doutorado e pelo apoio financeiro para a realização desta pesquisa.

Ao Emiliano, que teve uma participação fundamental ao longo de todo o trabalho, auxiliando desde as primeiras idéias embrionárias, no desenvolvimento dos programas utilizados para obtenção dos dados junto aos especialistas, na implementação das redes neurais e no total apoio e paciência nos momentos de desespero. 
Aos meus pais, pelos longos anos de investimento, incentivo e apoio, aos quais devo minha formação, e por terem me ensinado que só levamos desta vida aquilo que vivemos e aprendemos, a eles dedico esta tese.

A todos muito obrigada! 


\section{RESUMO}

SPÖRL, C. . Metodologia para elaboração de modelos de fragilidade ambiental utilizando redes neurais artificiais. Tese (Doutorado) - Faculdade de Filosofia, Letras e Ciências Humanas, Universidade de São Paulo, São Paulo, 2007.

Este trabalho aborda o desafio da modelagem da fragilidade ambiental, que implica em, além de compreender a intrínseca e dinâmica relação existente entre as componentes físicas, bióticas e sócio-econômicas dos sistemas ambientais, em traduzir esse conhecimento num modelo matemático. Para elucidar essa dificuldade foram apresentados e comparados os resultados gerados por dois modelos empíricos de fragilidade ambiental amplamente utilizados no planejamento físico-territorial brasileiro (CREPANI et al. 2001 e ROSS, 1994). Estes dois modelos foram aplicados em duas áreasteste, com resultados bastante divergentes. Neste contexto de incertezas, este trabalho testou a viabilidade e a confiabilidade de uma nova ferramenta a ser aplicada na elaboração de modelos de fragilidade ambiental, as redes neurais artificiais (RNAs). Empregando os conhecimentos e experiências de especialistas na área em questão, extraídos das respostas dadas por estes durante a comparação de variáveis e cenários aplicados através dos programas adaptados para esta finalidade: Pesquisa de Calibração, Pesquisa de Escalonamento de Variáveis e Pesquisa de Avaliação de Cenários. Estes programas geraram uma base de dados referente ao modo de avaliação de cada especialista quanto à fragilidade ambiental, sendo aplicada no treinamento das RNAs, para que a rede assimilasse o padrão de avaliação deste especialista. Os resultados comprovam de que é possível emular, com razoável confiabilidade, o padrão de avaliação de especialistas na definição da fragilidade dos sistemas ambientais, eliminando assim, a arbitrariedade e a subjetividade do processo de elaboração de modelos de fragilidade ambiental. Este trabalho não propõe um novo modelo, mas uma metodologia para a construção de modelos, utilizando redes neurais artificiais, dando um primeiro passo em busca de novas técnicas, temidas pelos geógrafos, mas necessárias para a evolução da ciência geográfica.

Palavras-chave: Fragilidade ambiental, modelos e redes neurais artificiais. 


\begin{abstract}
SPÖRL, C. . Methodology for the elaboration of environmental fragility models using artificial neural networks. Thesis (Ph D) - University of São Paulo, School of Philosophy, Languages and Literature and Liberal Arts, São Paulo, 2007.
\end{abstract}

This paper deals with the challenge in modeling environmental fragility, which implies not only the understanding of the intrinsic and dynamic relationship that exists between the physical, biotic and socio-economic components of environmental systems, but also in translating this knowledge in a mathematical model. In order to shed light on this difficulty, the results generated by two empirical models of environmental fragility were presented and compared, models that are widely used in Brazilian physical-territorial planning. (CREPANI et al. 2001 and ROSS, 1994). These two models were applied in two thesis-areas with very diverging results. Within this context of uncertainties, this paper tested the feasibility and reliability of a new tool to be applied in the elaboration of environmental fragility models, the artificial neural networks (ANN). Tapping on the knowledge and experience of specialists in this area, extracted from the answers given by them during the comparison of variables and scenarios applied in programs adapted for this objective: Gauging Research, Scheduling of Variables Research and Scenario Evaluation Research. These programs generated a databank related to the evaluation format of each specialist regarding environmental fragility applied in the training of ANNs, so that the network would assimilate the evaluation standard of that specialist. The results proved that it is possible to emulate, with reasonable reliability, the evaluation standard of specialists in the definition of environmental systems fragility, eliminating in this way, arbitrariness and subjectivity in the elaboration process of environmental fragility models. This work does not presuppose a new model, rather a methodology for the construction of models, using artificial neural networks, taking the first step in the search of new techniques, albeit feared by the geographers, however, necessary for the evolution of geographic science.

Key words: Environmental fragility, models and artificial neural networks. 


\section{SUMÁRIO}

PÁG.

AGRADECIMENTOS

RESUMO

5

ABSTRACT

LISTA DE FIGURAS

LISTA DE GRÁFICOS

LISTA DE QUADROS

LISTA DE FOTOS 16

LISTA DE ABREVIATURAS 17

1 - PRESSUPOSTOS DA PESQUISA E SEUS OBJETIVOS 18

2 - FUNDAMENTAÇÃO TEÓRICA-METODOLÓGICA

2.1 - ANÁLISE INTEGRADA DA PAISAGEM

2.2 - FRAGILIDADE/ VULNERABILIDADE AMBIENTAL 24

2.3 - PROCESSOS EROSIVOS 26

2.4 - SISTEMA DE INFORMAÇÃO GEOGRÁFICA 28

2.5 - MODELOS DE FRAGILIDADE/VULNERABILIDADE AMBIENTAL 29

2.6 - SISTEMAS DE SUPORTE À DECISÃO 31

2.6.1 - Processo Analítico Hierárquico 32

2.6.2 - Redes Neurais Artificiais (RNAs) 33

3 - ÁREA DE ESTUDO 36

3.1 - ÁREA-TESTE 1

3.1.1 - Planalto de São João da Boa Vista - Águas da Prata 40

3.1.2 - Serras da Borda do Maciço Intrusivo de Poços de Caldas 42

3.1.3 - Planalto de Poços de Caldas 44

3.2 - ÁREA-TESTE 2

3.2.1 - Localização $\quad 45$

3.2.1 - Bacia de Taubaté

3.2.2 - Morros Cristalinos

3.2.3 - Serra da Mantiqueira

4 - PROCEDIMENTOS TÉCNICO-OPERACIONAIS 
4.1 - PRIMEIRO NÍVEL: COMPILATÓRIO

4.2 - SeGundo Nível: CORRELATÓRIO

4.3 - TERCEIRO NÍVEL: SEMÂNTICO (INTERPRETATIVO)

4.4 - QUARTO NÍVEL: NORMATIVO

5 - MATERIAIS E MÉTODOS 59

5.1 - Produtos Cartográficos E IMAGens UtILIZAdOS 59

5.2 - Descrição dos Produtos Gráficos e Cartográficos Primários Gerados 60

5.2.1 - Carta Hipsométrica 60

5.2.2 - Carta Clinográfica 60

5.2.3 - Mapa Geológico 61

5.2.4 - Mapa Pedológico $\quad 62$

5.2.5 - Dados Climáticos 63

5.3 - Descrição dos Produtos Cartográficos INTERMEDIÁRIOS GeRAdOS 66

5.3.1 - Mapa Geomorfológico 66

5.3.2 - Mapa de Uso da Terra/Cobertura Vegetal $\quad 71$

6 - MODELOS DE FRAGILIDADE AMBIENTAL

6.1 - MOdelo de FraGilidade COM BASE NOS ÍNDICES De DisSECAÇÃO DO ReleVO 73

6.1.1 - Solos 73

6.1.2 - Índices de Dissecação do Relevo

6.1.3 - Uso da Terra/Cobertura Vegetal 77

6.1.4 - Comportamento Pluviométrico 78

6.2 - MODELO DE FRAGILIDADE COM BASE EM UTBS - UNIDADES TERRITORIAIS BÁSICAS

6.2 .1 - Geologia 83

6.2.2 - Pedologia 84

6.2.3 - Geomorfologia 86

6.2.4 - Cobertura Vegetal 90

6.2.5 - Clima 91

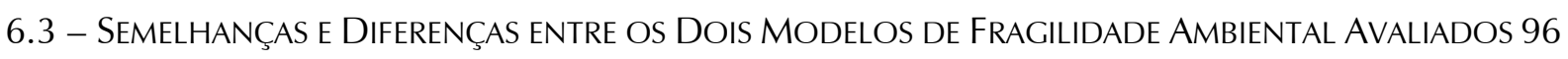

7 - REDES NEURAIS ARTIFICIAIS - UMA NOVA PROPOSTA METODOLÓGICA PARA A ELABORAÇÃO DE MODELOS DE FRAGILIDADE AMBIENTAL 98

$\begin{array}{ll}7.1 \text { - SELEÇÃO DAS VARIÁVEIS } & 100\end{array}$

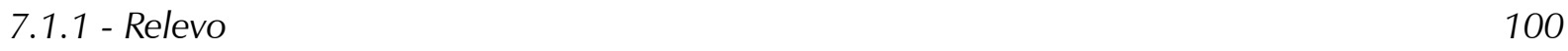

$\begin{array}{ll}\text { 7.1.2 - Solos } & 101\end{array}$

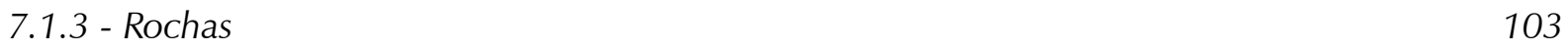

7.1.4 - Cobertura Vegetal/ Uso da Terra 104

$\begin{array}{ll}7.1 .5 \text { - Intensidade Pluviométrica } & 105\end{array}$

7.2 - IMPLEMENTAÇÃO DO SOFTWARE DE ELABORAÇÃO DE MODELOS 106

$\begin{array}{ll}\text { 7.2.1 - Programas Desenvolvidos } & 107\end{array}$

7.2.2 - Pesquisa de Escalonamento de Variáveis 110

$\begin{array}{ll}7.2 .3 \text { - Pesquisa de Avaliação de Cenários. } & 111\end{array}$ 
7.2.4 - As Comparações (Simulações) e os Especialistas

7.3 - ReCONHECIMENTO DE PADRÕES - REDES NeURAIS ARTIFICIAIS

7.3.1 - As Redes Neurais Artificiais (RNAs)

7.3.2 - Configuração da Rede Neural Artificial

7.3.3 - Treinamento

7.3.4 - Verificação ou Teste

8 - RESULTADOS DAS COMPARAÇÕES E DO TREINAMENTO DAS REDES NEURAIS ARTIFICIAIS

8.1 - RESULTADOS DO TREINAMENTO DAS RNAS DE CADA ESPECIALISTA

8.2 - ANÁLISE DOS DADOS E MAPAS GERADOS PELAS RNAS DE CADA ESPECIALISTA

9- COMPARAÇÃO ENTRE OS MODELOS EXISTENTES - CREPANI E ROSS - E SUAS RESPECTIVAS RNAS

9.1 - COMPARAÇÃO DOS MODELOS

9.1.1 - Modelo Crepani et al. (2001) x Modelo Ross (1994)

9.1.2 - Modelo Crepani et al. (2001) x RNA Crepani

9.1.3 - Modelo Ross (1994) x RNA Ross

9.1.4 - RNA Crepani x RNA Ross

9.2 - AVALIAÇÃO DOS RESULTADOS 166

10- CONSIDERAÇÕES FINAIS 168

11- BIBLIOGRAFIA

\section{ANEXOS}

Anexo I

Anexo II. 


\section{LISTA DE FIGURAS}

PÁG.

Figura 3.1 - Localização das áreas-teste..................................................... 36

Figura 3.2 - Localização da Área-teste 1 ..........................................................38

Figura 3.3 - Hipsometria e declividade da Área-teste 1 ..........................................39

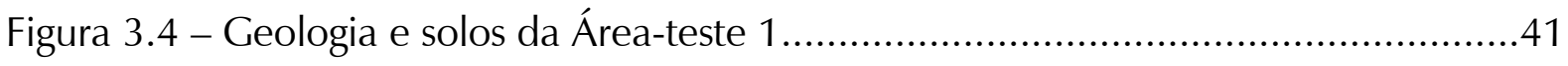

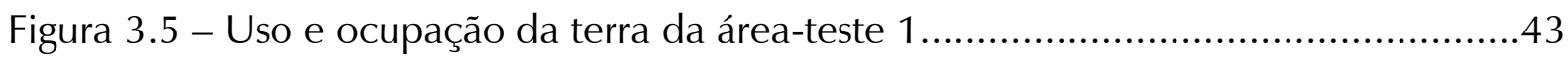

Figura 3.6 - Localização da Área-teste 2 .........................................................46

Figura 3.7 - Hipsometria e declividade da Área-teste 2 ........................................48

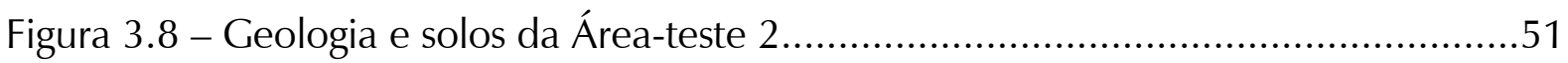

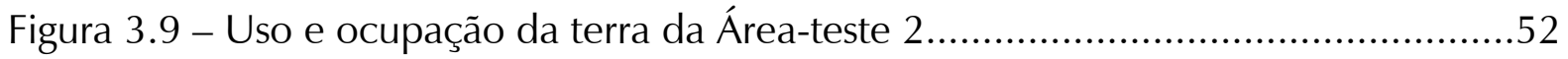

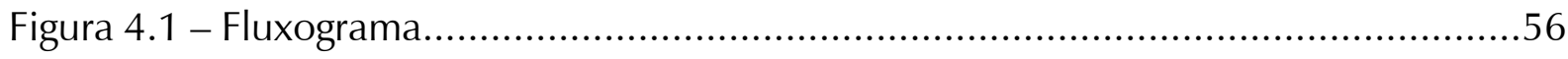

Figura 5.1 - Localização dos postos pluviométricos das áreas-teste 1 e 2 .....................65

Figura 5.2 - Geomorfologia da Área-teste 1 ..................................................69

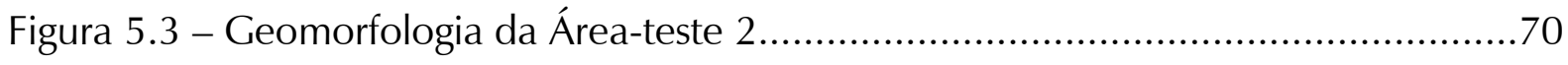

Figura 6.1 - Padrões de dissecação do relevo (A) e exemplos de padrões de dissecação (B)

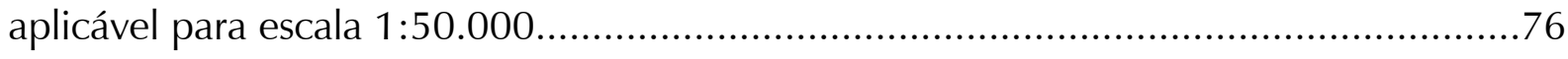

Figura 6.2 - Modelo esquemático do relevo.....................................................88

Figura 6.3 - Fragilidade ambiental - Área-teste 1 ..............................................94

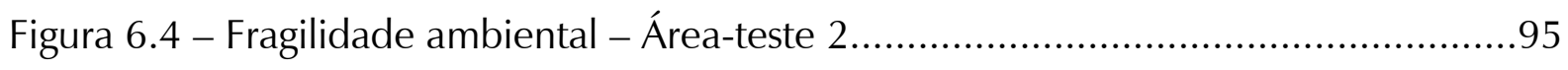

Figura 7.1 - Exemplo de avaliação comparativa da pesquisa de calibração...................108

Figura 7.2 - Exemplo de resultado da pesquisa de calibração.................................109

Figura 7.3 - Avaliação comparativa da variável solo............................................111

Figura 7.4 - Avaliação comparativa de dois cenários hipotéticos...............................112

Figura 7.5 - Arquitetura da RNA treinada.........................................................118

Figura 8.1 - Exemplo de processo de treinamento da RNA .................................124 
Figura 8.2 - Resultados da RNA treinada - Ailton................................................132

Figura 8.3 - Resultados da RNA treinada - Crepani..........................................133

Figura 8.4 - Resultados da RNA treinada - Déborah...........................................134

Figura 8.5 - Resultados da RNA treinada - Emerson.......................................135

Figura 8.6 - Resultados da RNA treinada - Marisa................................................136

Figura 8.7 - Resultados da RNA treinada - Ross...........................................137

Figura 9.1 - Comparação dos modelos: Crepani et al. (2001) x Ross (1994) - Área-teste

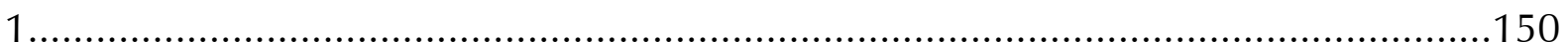

Figura 9.2 - Comparação dos modelos: Crepani et al. (2001) x Ross (1994) - Área-teste 2 . .151

Figura 9.3 - Comparação dos modelos: Crepani et al. (2001) x RNA Crepani - Área-teste

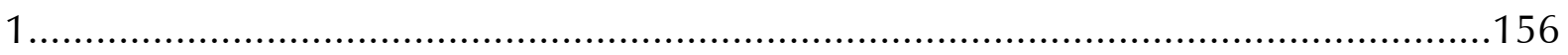

Figura 9.4 - Comparação dos modelos: Crepani et al. (2001) x RNA Crepani - Área-teste

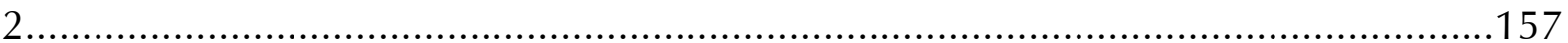

Figura 9.5 - Comparação dos modelos: Ross (1994) x RNA Ross - Área-teste

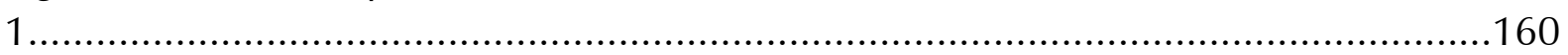

Figura 9.6 - Comparação dos modelos: Ross (1994) x RNA Ross - Área-teste 2. .161

Figura 9.7 - Comparação dos modelos: RNA Crepani x RNA Ross - Área-teste

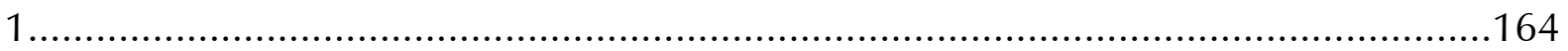

Figura 9.8 - Comparação dos modelos: RNA Crepani x RNA Ross - Área-teste

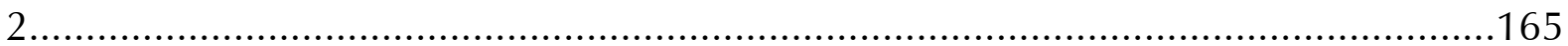




\section{LISTA DE GRÁFICOS}

PÁG.

Gráfico 3.1 - Totais pluviométricos do posto C3-034, localizado em Águas da Prata, para o ano de 1999.

Gráfico 3.2 - Totais pluviométricos do posto C3-031, localizado em São João da Boa Vista, para o ano de 1999.

Gráfico 3.3 - Totais pluviométricos do posto D2-068, localizado em Pindamonhangaba, para o ano de 1999

Gráfico 3.4 - Totais pluviométricos do posto D2-070, localizado em Pindamonhangaba, para o ano de 1999

Gráfico 8.1 - Análise de acertos - RNA Ailton.

Gráfico 8.2 - Análise de acertos - RNA Crepani.

Gráfico 8.3 - Análise de acertos - RNA Déborah

Gráfico 8.4 - Análise de acertos - RNA Emerson.

Gráfico 8.5 - Análise de acertos - RNA Marisa.

Gráfico 8.6 - Análise de acertos - RNA Ross

Gráfico 8.7 - Representação das ponderações dadas às alternativas de declividade dominante pelos seis especialistas.

Gráfico 8.8 - Representação das ponderações dadas às alternativas de solos pelos seis especialistas

Gráfico 8.9 - Representação das ponderações dadas às alternativas de uso da terra/cobertura vegetal pelos seis especialistas.

Gráfico 8.10 - Representação das ponderações dadas às alternativas de intensidade pluviométrica pelos seis especialistas.

Gráfico 8.11 - Representação das ponderações dadas às alternativas de rochas pelos seis especialistas.

Gráfico 9.1 - Análise de acertos entre os Modelos Crepani et al. (2001) e Ross (1994) Área-teste 1

Gráfico 9.2 - Análise de acertos entre os Modelos Crepani et al. (2001) e Ross (1994) Área-teste 2 . 
Gráfico 9.3 - Análise de acertos entre os Modelos Crepani et al. (2001) e RNA Crepani Área-teste 1

Gráfico 9.4 - Análise de acertos entre os Modelos Crepani et al. (2001) e RNA Crepani Área-teste 2

Gráfico 9.5 - Análise de acertos entre os Modelos Ross (1994) e RNA Ross Área-teste $1 . .$. .158

Gráfico 9.6 - Análise de acertos entre os Modelos Ross (1994) e RNA Ross Área-teste 2

Gráfico 9.7 - Análise de acertos entre os Modelos RNA Crepani (2001) e RNA Ross Áreateste 1

Gráfico 9.8 - Análise de acertos entre os Modelos RNA Crepani (2001) e RNA Ross ÁreaTeste 2. 


\section{LISTA DE QUADROS}

PÁG.

Quadro 5.1 - Documentos cartográficos e imagens. .59

Quadro 5.2 - Rochas ocorrentes nas áreas-teste.

Quadro 5.3 - Solos ocorrentes nas áreas-teste.

Quadro 5.4 - Dados dos postos pluviométricos.

Quadro 5.5 - Padrões de formas do relevo.

Quadro 5.6 - Matriz dos índices de dissecação do relevo. .68

Quadro 6.1 - Classes de fragilidade dos solos. .74

Quadro 6.2 - Matriz dos índices de dissecação do relevo. .75

Quadro 6.3 - Classes de dissecação do relevo. .77

Quadro 6.4 - Graus de proteção do solo segundo a cobertura vegetal.. 77

Quadro 6.5 - Níveis hierárquicos das variações pluviométricas. 79

Quadro 6.6 - Avaliação da vulnerabilidade das unidades de paisagem natural.

Quadro 6.7 - Escala de vulnerabilidade das rochas.

Quadro 6.8 - Valores de vulnerabilidade/estabilidade dos solos. 86

Quadro 6.9 - Classes dos índices morfométricos. .87

Quadro 6.10 - Matriz dos índices de dissecação do relevo.....

Quadro 6.11 - Graus de proteção do solo segundo a cobertura vegetal. .90

Quadro 6.12 - Escala de erosividade da chuva .92

Quadro 6.13 - Graus de vulnerabilidade/estabilidade.

Quadro 6.14 - Variáveis avaliadas pelos modelos empíricos. .96

Quadro 7.1 - Identificação dos especialistas consultados. 114

Quadro 8.1 - Interpretação dos coeficientes de correlação.

Quadro 8.2 - Coeficiente de correlação dos testes das RNAs.

Quadro 9.1 - Graus de vulnerabilidade/estabilidade. 146 
Quadro 9.2 - Processo utilizado para representação gráfica das convergências e divergências no mapa simplificado.........................................................148

Quadro 9.3 - Coeficiente de correlação entre os modelos.........................................166 


\section{LISTA DE FOTOS}

PÁG.

Foto 3.1 - Pastagens no Planalto de São João da Boa Vista-Águas da Prata.....................43

Foto 3.2 - Cultivo de batata em São João da Boa Vista............................................43

Foto 3.3 - Formações florestais nas escarpas íngremes da região serrana e na média

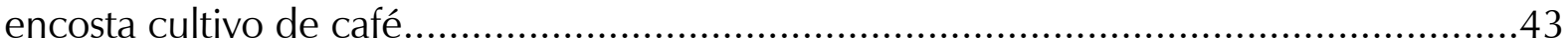

Foto 3.4 - Formações campestres do Planalto de Poços de Caldas...............................43

Foto 3.5 - Arroz irrigado nas planícies do Rio Paraíba do Sul.....................................52

Foto 3.6 - Áreas de Latossolo Amarelo destinadas à pastagem .................................52

Foto 3.7 - Relevo dissecado da Serra da Mantiqueira..........................................52

Foto 3.8 - Vegetação de campo de altitude na Serra da Mantiqueira..........................52 


\section{LISTA DE ABREVIATURAS}

AHP - Processo Analítico Hierárquico

DNPM - Departamento Nacional da Produção Mineral

EUPS - Equação Universal de Perda de Solos

IA - Inteligência Artificial

IAC - Instituto Agronômico de Campinas

GPS - Sistema de Posicionamento Global

INPE - Instituto Nacional de Pesquisas Espaciais

MNT - Modelo Numérico do Terreno

RNA - Rede Neural Artificial

SIG - Sistema de Informação Geográfica

SSD - Sistema de Suporte à Decisão

TIN - Triangular Irregular Network

USLE - Universal Soil Loss Equation

UTB - Unidade Territorial Básica 


\section{1 - PRESSUPOSTOS DA PESQUISA E SEUS OBJETIVOS}

Em princípio os ambientes naturais mostravam-se em estado de equilíbrio dinâmico, no entanto, as sociedades humanas passaram progressivamente a intervir cada vez de forma mais intensa na apropriação dos recursos naturais, causando significativas alterações na paisagem num ritmo mais intenso que o determinado pela natureza.

Os sistemas ambientais, face às intervenções humanas, apresentam maior ou menor fragilidade em função de suas características "genéticas". Qualquer alteração nos diferentes componentes da natureza (relevo, solo, vegetação, clima e recursos hídricos), resulta no comprometimento da funcionalidade do sistema, quebrando o seu estado de equilíbrio dinâmico. Diante disto é imprescindível que se façam inserções antrópicas totalmente compatíveis com a potencialidade dos recursos de um lado e com a fragilidade dos ambientes naturais de outro, o que torna cada vez mais urgente o Planejamento Físico Territorial não só com a perspectiva econômica-social, mas também ambiental.

O planejamento é um instrumento para racionalizar a ocupação, sempre se levando em conta as limitações e fragilidades dos ecossistemas, e para redirecionar as atividades econômicas, servindo de subsídio às estratégias e ações de planos regionais em busca do desenvolvimento sustentável. Consiste em otimizar tanto o uso do espaço quanto as políticas públicas.

Neste sentido os estudos relativos à fragilidade dos ambientes são de significativa importância para o planejamento ambiental, pois se trata de um instrumento cuja finalidade é identificar e analisar os ambientes em função de seus diferentes níveis de susceptibilidade. Proporcionando assim, uma melhor definição das diretrizes e ações a serem implementadas no espaço físico-territorial, servindo de base para o zoneamento e fornecendo subsídios à gestão do território.

O estudo relativo à fragilidade ambiental tem como produto final um mapeamento síntese que permite identificar áreas com maior ou menor vulnerabilidade, conseqüentemente, aponta áreas mais ou menos suscetíveis aos processos erosivos.

Esta susceptibilidade também está relacionada aos processos erosivos mecânicos das águas pluviais de um lado, e de outro lado, à qualidade das águas de superfície em função da carga de sedimentos acumulados. Os processos erosivos colocam em risco a estabilidade dos terrenos e das águas propiciando o carreamento de materiais tóxicos até as drenagens contribuindo para a perda de qualidade das águas superficiais. E ainda estes sedimentos podem assorear rios e contribuir com o agravamento do problema de inundações.

Desta forma, fica evidente que a ocupação desordenada acelera os processos erosivos, aumentando a perda de solo superficial, comprometendo a sustentabilidade do sistema e a quantidade e qualidade dos recursos hídricos. Os assoreamentos dos cursos d'água e 
inundações também estão intimamente relacionados aos processos erosivos. Neste contexto, a erosão acelerada cria sérios problemas, não só na agricultura, ocasionando perda gradual na capacidade produtiva, mas também no manejo dos recursos hídricos, contaminando-os com sedimentos e poluentes de origem difusa. Estes problemas não são apenas de ordem técnica, mas também social e econômico.

Neste sentido o objetivo do mapeamento da fragilidade ambiental é representar o conhecimento do comportamento atual do terreno em relação às respostas aos processos erosivos, distinguindo as áreas onde os riscos de erosão são mais baixos favorecendo, então, determinados tipos de inserção; e também, aquelas áreas mais frágeis, ou seja, mais suscetíveis aos processos erosivos, onde são exigidas ações tecnicamente mais adequadas a essas condições.

Estes mapeamentos da fragilidade ambiental consistem em uma das principais ferramentas utilizadas pelos órgãos públicos na elaboração do planejamento territorial ambiental, permitem avaliar as potencialidades do meio ambiente de forma integrada, compatibilizando suas características naturais com suas restrições. São orientativos para tomada de decisões, pois apresentam as informações necessárias para que planejadores possam identificar as melhores ações a serem implementadas.

Para que estes mapeamentos sejam aplicados em grandes áreas territoriais é necessário se utilizar de modelos. Estes modelos são uma representação simplificada da realidade para facilitar a descrição, a compreensão do funcionamento atual e do comportamento futuro das questões relacionadas às potencialidades e fragilidades.

Os modelos relacionados à questão da vulnerabilidade ambiental dividem-se em dois tipos: modelos quantitativos e modelos qualitativos.

Os modelos quantitativos procuram estimar as variações e perdas de solos, ou seja, visam quantificar os fenômenos da erosão. Dentre as metodologias disponíveis para a predição de perda de solos a mais utilizada é a Equação Universal de Perda de Solos (EUPS). Já os modelos qualitativos têm como objetivo avaliar o fenômeno da erosão no que se refere a sua origem e evolução, os condicionantes e mecanismos que as fazem surgir e que atuam no seu desenvolvimento.

A elaboração destes dois tipos de modelo está pautada em diferentes formas de construção: os modelos quantitativos se baseiam em medições e experimentos, e os modelos qualitativos são modelos empíricos que estão baseados na experiência de especialistas.

Este trabalho aqui apresentado está focado nos modelos qualitativos, os quais estão direcionados a avaliar os condicionantes e mecanismos que influenciam na questão da vulnerabilidade ambiental. Estes modelos são elaborados por especialistas no assunto e baseados nos seus respectivos conhecimentos e experiências adquiridos. 
Dentre estes modelos, amplamente utilizados, para a análise empírica da fragilidade ambiental podem ser citados dois modelos propostos por Ross (1994), um com base nos Índices de Dissecação do Relevo, e o outro, nas Classes de Declividade; e ainda, o modelo sugerido por Crepani et al. (2001) com base em Unidades Territoriais Básicas (UTBs).

Estes modelos têm como ponto comum o entendimento da inter-relação dos elementos do meio físico.

Estes modelos empíricos de fragilidade ambiental, apesar de utilizarem praticamente as mesmas variáveis, apresentam diferentes formas de calcular a vulnerabilidade, e "pesos" distintos para cada uma destas variáveis envolvidas na obtenção dos graus de fragilidade. Conseqüentemente, segundo Spörl (2001), os mapas sínteses resultantes da aplicação destes modelos apresentam resultados bastante divergentes decorrentes destas diferenças técnico-operacionais.

Diante disto, segundo Spörl (2004), surgem algumas questões: a) Qual a melhor forma de avaliar a vulnerabilidade ambiental? b) Quais os pesos corretos a serem aplicados para cada uma das variáveis utilizadas para a obtenção dos graus de fragilidade? c) Os resultados apresentados por estes modelos de análise da fragilidade ambiental são confiáveis?

Para uma melhor avaliação sobre a eficácia destes modelos de análise de fragilidade ambiental, visando ainda identificar o modelo que melhor se ajusta ao que ocorre na natureza, é necessário correlacionar os problemas de erosão, deslizamentos e perda de qualidade das águas de superfície encontrados em campo com os modelos empíricos. Só assim será possível apontar um modelo que melhor condiz com a realidade.

Algumas pesquisas que correlacionam resultados da aplicação destes modelos de fragilidade ambiental e da investigação de campo demonstram que nem sempre os resultados são convergentes. Como exemplos, podem ser citados os trabalhos de Nakashima (1999) e de Rodrigues (1998), que mostram que freqüentemente os resultados dos modelos não condizem com as respostas da natureza.

Este tipo de divergência pode ocorrer devido aos seguintes fatores:

- Falha na aplicação da metodologia. Estas falhas podem ocorrer devido a dados incorretos, erro na tabulação de dados, ou aplicação errônea do modelo.

- Pouca "aderência" entre o modelo e o conhecimento científico-tecnológico. Isto significa que o conhecimento científico não está refletido no modelo. Desta forma, o modelo não consegue traduzir exatamente estes conhecimentos, há um descompasso entre o modelo e o conhecimento. 
- Limitações da capacidade preditiva do modelo, ou seja, o modelo apresenta limitações significativas. Portanto, deve-se avaliar até que ponto é válida a sua aplicação.

Diante disto, todo modelo precisa ser testado, ser validado ou, mais importante ainda, ser falseado. Os modelos devem estar num contínuo processo de busca de erros para a sua depuração. Pode-se dizer que o objetivo mais importante é verificar sob quais condições o modelo não funciona, ou seja, verificar e comprovar quais as limitações dos modelos.

Openshaw e Openshaw (1997) reportam que há a necessidade de considerar a reengenharia de modelos existentes através da Computação Inteligente, a fim de explorar a não-linearidade, adaptabilidade, incerteza etc. desses modelos.

Neste contexto, este estudo espera gerar uma discussão a respeito dos métodos de construção destes modelos empíricos já consagrados. Sabemos dos vastos conhecimentos e experiência dos especialistas que elaboraram estes modelos, no entanto, também é amplamente sabida a dificuldade de se construir modelos. A construção de modelos não é algo simples, principalmente quando está em questão a dinâmica do sistema ambiental, um assunto que não é um consenso entre os especialistas.

Desta forma, o objetivo deste trabalho não é criticar nem desmerecer os modelos já consagrados, mas sim, propor uma nova forma de abordar a fragilidade ambiental utilizando os conhecimentos dos especialistas com base em conceitos mais científicos. Desenvolvendo-se uma nova metodologia para a elaboração de modelo de fragilidade aplicando-se técnicas de Inteligência Artificial, as redes neurais artificiais (RNAs), onde talvez possam ser minimizadas as limitações apresentadas nos modelos já existentes.

As redes neurais artificiais (RNAs) são técnicas computacionais que apresentam um modelo matemático inspirado na estrutura neural de organismos inteligentes tentando emular em máquinas (computadores) o funcionamento do cérebro humano de uma maneira simplificada. Assim como o cérebro humano, a RNA é capaz de aprender e tomar decisões baseadas na aprendizagem adquirida. Desta forma, a RNA pode ser interpretada como um esquema de processamento capaz de armazenar conhecimento baseado em aprendizagem (experiência) e disponibilizar este conhecimento para a aplicação do tema em questão.

A RNA é capaz de reconhecer padrões, ou seja, possui a capacidade de aprender por meio de exemplos e de generalizar a informação aprendida, gerando um modelo não linear, o que torna a sua aplicação na análise ambiental bastante eficiente.

O sucesso das RNAs para modelar sistemas dinâmicos em vários campos da ciência e da engenharia sugere que elas também possam ser aplicadas nos modelos de fragilidade ambiental. A utilização das RNAs na análise ambiental torna disponível essa nova ferramenta para decisões complexas, que envolvem muitos critérios, sendo que a seleção 
dos critérios, assim como a definição de seus pesos, são avaliações arbitrárias e subjetivas, dificultando o processo de análise.

Diante do exposto, este estudo tem como objetivo principal desenvolver e testar as redes neurais artificiais (RNAs) como uma nova alternativa metodológica à elaboração de modelos de análise da fragilidade ambiental, visando aprimorar os métodos empíricos já existentes.

Pretende-se testar a viabilidade e a confiabilidade desta nova ferramenta nos estudos da fragilidade ambiental, adotando as seguintes etapas:

- Implementar um sistema de apoio à tomada de decisão através do reconhecimento de padrões adotados por especialistas da área de domínio, utilizando RNAs e adotando-se a metodologia proposta por Castro (1998) como base para uma nova abordagem do modelo de fragilidade ambiental;

- Testar essa nova ferramenta proposta para análise da fragilidade ambiental, as RNAs, no reconhecimento do padrão de avaliação dos especialistas consultados;

- Apresentar e aplicar os modelos empíricos existentes de fragilidade ambiental propostos por Ross (1994) e por Crepani et al. (2001) em duas áreas-teste para comparar o desempenho destes modelos em diferentes cenários;

- Compara os modelos empíricos propostos por Ross (op. cit.) e por Crepani et al. (op. cit.) com os resultados gerados pelo treinamento das suas respectivas RNAs;

- Avaliar se há um consenso entre os especialistas na complexa questão da fragilidade ambiental. 


\section{2 - FUNDAMENTAÇÃO TEÓRICA-METODOLÓGICA}

Neste capítulo são apresentados os conceitos básicos relevantes ao desenvolvimento desta pesquisa que envolve diferentes temas.

São abordadas as questões ligadas à análise da fragilidade ambiental, assim como, a interrelação e dinâmica dos componentes da natureza, alterações na dinâmica que geram a ruptura do equilíbrio dinâmico, níveis de vulnerabilidade, os processos erosivos, e os modelos de fragilidade ambiental.

Também são abordados temas que deram suporte ao desenvolvimento de uma nova metodologia para a elaboração de modelo de fragilidade ambiental utilizando-se redes neurais artificiais (RNAs), assim como, ferramentas que auxiliam a análise integrada e complexa dos componentes da natureza, bem como o SIG, sistema de suporte à decisão e processo analítico hierárquico (AHP).

\section{1 - ANÁLISE INTEGRADA DA PAISAGEM}

Este estudo propõe realizar uma análise numa abordagem sistêmica visando à compreensão integrada do ambiente físico e dos processos antrópicos atuantes na área.

Seguindo os pressupostos geossistêmicos de Sotchava (1976), acredita-se que a preocupação central dos estudos da Geografia Física, não é simplesmente estudar os componentes da natureza, mas sim, as conexões entre eles, o estudo não deve ficar restrito a morfologia da paisagem e suas subdivisões, mas extrapolar para o estudo da sua dinâmica, não deixando de lado a conexão entre o homem e a natureza.

Além dos aspectos naturais, o meio antrópico é parte fundamental no entendimento da paisagem. Segundo Bertrand (1971), a paisagem não é a simples adição de elementos disparatados, é numa determinada porção do espaço o resultado da combinação dinâmica, portanto instável, de elementos físicos, biológicos e humanos que reagindo dialeticamente uns sobre os outros fazem da paisagem um conjunto único e indissociável, em perpétua evolução. É preciso deixar claro que não se trata apenas da paisagem "natural", mas da paisagem total integrando todas as implicações da ação humana.

Grigoriev (1968) destaca o caráter dinâmico e interativo entre os diversos estratos geográficos terrestres, compostos pela crosta terrestre, hidrosfera, troposfera, cobertura vegetal e reino animal, que em conjunto, definem os ambientes onde vivem os homens. Este autor assegura que o estrato geográfico só pode ser estudado com sucesso, quando o efeito da sociedade humana e de seus modos de produção sobre a natureza forem rigorosamente levados em consideração. Sendo assim, nossa tarefa é estudar os componentes do estrato geográfico como partes de um todo, não isoladamente.

De acordo com Monteiro (1978): 
O Geossistema é um sistema singular, complexo, onde interagem elementos humanos, físicos, químicos e biológicos, e onde os elementos sócio-econômicos não constituem um sistema antagônico e oponente, mas sim estão incluídos no funcionamento do próprio sistema.

Segundo Troppmair (1988) a paisagem é um sistema espacial dinâmico de fenômenos naturais e sócio-econômicos. A paisagem é uma realidade independente da presença do homem. Se este estiver presente, introduz modificações, ou mesmo, desequilíbrio nesta realidade.

Seguindo essa concepção Tricart (1977) analisa o ambiente sob o prisma da Teoria dos Sistemas que parte do pressuposto de que na natureza as forças de energia e matéria se processam através de relações de equilíbrio dinâmico. Entretanto, este equilíbrio, é freqüentemente alterado pelas intervenções do homem nos diversos componentes da natureza, gerando estado de desequilíbrios temporários ou até permanentes. Sendo assim, Tricart (op. cit.) definiu que os ambientes, quando estão em equilíbrio dinâmico são estáveis, e quando, em desequilíbrio são instáveis.

Qualquer alteração realizada em algum dos componentes de um sistema em equilíbrio dinâmico reflete-se de uma forma ou de outra sobre os demais componentes deste sistema, provocando a ruptura do equilíbrio dinâmico que, ao ultrapassar limiares, leva a uma situação de instabilidade.

Segundo Drew (1989) a magnitude desta instabilidade depende primeiramente do esforço (ou tensão) aplicado ao sistema pelo homem e, do grau de susceptibilidade à mudança (sensibilidade) do próprio sistema.

Neste sentido, o mapeamento da fragilidade ambiental através do estudo integrado dos componentes da natureza classifica o sistema em diferentes níveis de vulnerabilidade. Reconhecendo assim, as áreas mais suscetíveis à instabilidade (processos erosivos, deslizamentos, assoreamentos e inundações), ou seja, aquelas áreas que pelas suas características "genéticas" podem facilmente ser alteradas.

\section{2 - FRAGILIDADE/ VULNERABILIDADE AMBIENTAL}

As condições de estabilidade/equilíbrio do sistema podem ser rompidas através de alterações realizadas em qualquer um dos componentes da natureza, gerando instabilidade. Qualquer intervenção realizada, não respeitando as vulnerabilidades do sistema, pode acarretar alterações na sensibilidade da paisagem em função do rompimento de seus limiares, resultando então na fragilização deste sistema.

A maior ou menor facilidade com que este limiar pode ser rompido depende tanto das características "genéticas" dos sistemas ambientais quanto do uso que se faz da terra, desta forma, dependendo destas variáveis o ambiente pode ser classificado em diferentes níveis de fragilidade. 
O termo fragilidade ambiental está ligado à susceptibilidade do sistema de sofrer intervenções, ou de ser alterado. Quando é quebrado o estado de equilíbrio dinâmico o sistema pode entrar em colapso, passando para uma situação de risco. A desestabilização do sistema pode ter como indutores tanto processos naturais quanto ações antrópicas.

Vitte e Santos (1999) partem do significado dos termos fragilidade e meio ambiente para chegar ao conceito de fragilidade ambiental. De acordo com o Dicionário Aurélio o termo frágil é definido como algo fácil de destruir, pouco durável, transitório. Fragilidade é então, a qualidade do que é frágil. O ambiente é aquele que cerca ou envolve os seres vivos ou as coisas. Assim, o termo fragilidade do meio pode aparecer como ambiente de risco, ou risco ambiental, o qual se define como perigo ou possibilidade de perigo ou perda, que estão vinculadas à percepção humana da dinâmica da natureza.

Baseando-se nestes conceitos entende-se por fragilidade ambiental o grau de susceptibilidade a qualquer tipo de dano, ou seja, está relacionado aos ambientes em situação de risco. Dentre os fenômenos de risco mais freqüentes destacam-se as erosões, os deslizamentos de encostas, o assoreamento de cursos de água e as inundações.

Para se obter um panorama das condições de susceptibilidade do sistema é necessário, segundo Ross (1994), realizar um estudo integrado dos elementos componentes do estrato geográfico que dão suporte à vida animal e ao homem, os quais analisados e interrelacionados geram um produto analítico-sintético que retrata a situação da área de estudo. Esta análise integrada permite obter um diagnóstico das diferentes categorias hierárquicas da fragilidade dos ambientes naturais, resultando na carta síntese de Fragilidade/Vulnerabilidade Ambiental.

Esta carta síntese de vulnerabilidade ambiental, segundo Becker e Egler (1997) constitui um dos produtos síntese intermediário e representa a contribuição oferecida pelo meio físico-biótico à ocupação racional do território e o uso sustentável dos recursos naturais.

Conforme exposto em Câmara et al. (2001), na perspectiva moderna de gestão do território, toda ação de planejamento, ordenação ou monitoramento do espaço deve incluir a análise dos diferentes componentes do ambiente, incluindo o meio físicobiótico, a ocupação humana e seu inter-relacionamento.

A análise integrada dos ambientes naturais, proposta por Ross (1994), é fundamentada na concepção de Tricart (1977) a qual enfatiza a importância de se considerar no planejamento "não somente as potencialidades dos recursos naturais, mas, sobretudo as fragilidades dos ambientes naturais face as diferentes inserções dos homens na natureza". Este autor cita a importância de se conhecer o papel de cada variável, uma vez que cada uma delas apresenta um certo grau de influência no ambiente, interferindo com maior ou menor intensidade.

Desta forma, pode-se inferir que cada variável tem um grau de importância diferenciado na composição do nível de vulnerabilidade do sistema. Ou seja, as variáveis apresentam 
diferentes "pesos" (níveis de intensidade) os quais devem indicar sua contribuição relativa na definição do grau de fragilidade.

Estas variáveis (relevo, solo, rocha, clima e uso da terra/cobertura vegetal) apresentam uma relação extremamente dinâmica e complexa e uma alta interdependência. Ou seja, nos estudos ambientais nada está dissociado, todos os fenômenos se inter-relacionam, se completam e possuem uma dinâmica conjunta. Daí a necessidade de se analisar conjuntamente todas as variáveis.

Segundo Ross (1994) estes estudos devem refletir a integração dos conhecimentos destas variáveis, baseando-se sempre no princípio de que a natureza apresenta uma funcionalidade intrínseca entre suas componentes físicas e bióticas e desta maneira, torna-se possível avaliar a fragilidade destes ambientes.

A carta de fragilidade ambiental, segundo Ross (1991) auxilia o diagnóstico-síntese que pode perfeitamente nortear as intervenções antrópicas futuras e corrigir as presentes. É portanto, um instrumento importante no trabalho de planejamento físico territorial.

Desta forma, o estudo da fragilidade ambiental se constitui num passo indispensável à medida que, atualmente, é cada vez mais necessário conhecer e compreender a dinâmica do sistema e as transformações dele decorrentes para subsidiar o planejamento nas definições das ações prioritárias a serem tomadas, destinadas a assegurar a qualidade dos recursos hídricos e do solo, e a conservação da biodiversidade.

\section{3 - Processos EROSIVOS}

A apropriação dos recursos naturais de maneira a não atender as suas potencialidades e fragilidades conduz à instalação de processos degenerativos que são resultantes de quebras nos mecanismos de funcionamento e interdependência mantidos entre os seus componentes físico-bióticos. Dentre estes processos degenerativos, a erosão do solo é um dos mais graves.

A erosão é um processo natural de desagregação, decomposição, transporte e deposição de materiais de rochas e solos que vem agindo sobre a superfície terrestre desde os seus princípios. Contudo, a ação humana sobre a paisagem contribui exageradamente para a aceleração do processo, trazendo como conseqüências, a perda de solos férteis, a poluição da água, o assoreamento dos cursos d'água e reservatórios e a degradação e redução da produtividade tanto dos ecossistemas terrestres quanto aquáticos.

Os processos erosivos são condicionados basicamente por alterações do sistema, provocadas pelo uso do solo nas suas várias formas, desde o desmatamento e a agricultura, até obras urbanas e viárias, que, de alguma forma, propiciam a concentração das águas de escoamento superficial.

A erosão acelerada (ação antrópica) pode ser laminar ou em lençol, quando causada por escoamento difuso das águas das chuvas resultante na remoção progressiva dos 
horizontes superficiais do solo; e erosão linear, quando causada por concentração das linhas de fluxo das águas de escoamento superficial, resultando em incisões na superfície do terreno na forma de sulcos, ravinas e voçorocas.

A erosão do solo constitui, sem dúvida, a principal causa do depauperamento das terras. As enxurradas, provenientes das águas de chuva que não ficaram retidas sobre a superfície, ou não se infiltraram, transportam partículas de solo em suspensão e elementos nutritivos essenciais em dissolução. Outras vezes, esse transporte de partículas de solo se verifica pela ação do vento (BERTONI \& LOMBARDI NETO, 1999).

A erosão cria sérios problemas, não só na agricultura, ocasionando perda gradual na capacidade produtiva, mas também no manejo dos recursos hídricos, contaminando-os com sedimentos e poluentes de origem difusa, provocando a redução da produção de energia elétrica e do volume de água para abastecimento urbano devido ao assoreamento de reservatórios, além de uma série de transtornos aos demais setores produtivos da economia.

A erosão resulta da combinação de fatores que são dependentes e estão interligados entre si, apresentando grande variabilidade espacial e temporal. Dentre os principais fatores que influenciam no processo erosivo destacam-se a chuva, o solo, a topografia, a cobertura vegetal e a ação antrópica, assim como, o desmatamento e as formas de uso e ocupação do solo (agricultura, obras civis, urbanização etc.).

Os processos erosivos respondem com maior ou menor intensidade na proporção direta do desequilíbrio existente ou provocado. Assim, considerando-se a erosão segundo o aspecto natural, ela ocorre de forma mais intensa onde as características dos condicionantes do meio físico encontram-se mais vulneráveis. Ou seja, as características "genéticas" das variáveis ambientais determinam o grau de susceptibilidade aos processos erosivos.

É importante detectar os lugares onde a erosão apresenta-se em estágio mais avançado, visando definir medidas de correção e proteção ao meio, determinar as zonas mais sensíveis à erosão ao se planejar uma mudança de uso do solo e detectar os lugares onde o fenômeno erosivo é ou pode ser mais intenso com o propósito de se evitar prejuízos sobre obras a serem executadas. Torna-se relevante, portanto, dimensionar nos estudos a erosão atual (erosão que existe num determinado lugar, no momento presente) e a erosão potencial (susceptibilidade à erosão).

Segundo Lohmann (2005) existem métodos que visam à quantificação do fenômeno da erosão sob os aspectos reais e atuais numa determinada área de estudo, seja uma parcela, uma encosta ou mesmo uma bacia hidrográfica. Estes métodos procuram estimar e definir o peso, o volume e a profundidade de solo carreado, ou seja, variações e perdas em termos de quantidade. Dentre as metodologias disponíveis para a predição de perda de solos a mais utilizada é a Universal Soil Loss Equation (USLE) - Equação Universal de Perda de Solos (EUPS), desenvolvida por Wischmeier \& Smith em 1965. Muitos trabalhos 
concentram-se na compreensão do fenômeno ou mesmo no desenvolvimento de técnicas de recuperação do potencial produtivo de determinadas áreas já que a erosão está intimamente ligada à queda de produtividade.

Outros métodos podem ser definidos como qualitativos e têm como objetivo avaliar o fenômeno da erosão no que se refere a sua origem e evolução, os condicionantes e mecanismos que as fazem surgir e que atuam no seu desenvolvimento bem como a busca de medidas que venham a auxiliar na prevenção, no seu controle e estabilização.

Para entender o processo erosivo do ponto de vista qualitativo, ou seja, relacionado ao entendimento da susceptibilidade e do potencial de determinadas áreas à instalação desses processos, várias metodologias vem sendo testadas. Essas metodologias têm como ponto comum o entendimento da inter-relação dos elementos do meio físico. Dentre essas metodologias podem ser citadas como exemplo, as metodologias propostas por Crepani et al. (2001) e por Ross (1994).

Estas propostas metodológicas visam identificar áreas com maior ou menor susceptibilidade à perda de solo, assim como áreas vulneráveis aos processos erosivos, escorregamentos, assoreamentos, etc.

\section{4 - SISTEMA DE INFORMAÇÃO GEOGRÁFICA}

Dadas a complexidade e a dimensão dos procedimentos envolvidos nos estudos ambientais, os Sistemas de Informação Geográfica (SIGs) apresentam-se como uma importante ferramenta que auxilia a realização de análises complexas a partir da integração de representações de dados espaciais.

Os SIGs são definidos como tecnologias para investigação dos fenômenos ambientais que combinam os avanços tecnológicos da cartografia, banco de dados automatizados, sensoriamento remoto e modelagem. São conjuntos de programas computacionais utilizados para armazenar, analisar, manipular e gerenciar dados geográficos, com ênfase em análises espaciais e modelagens de superfícies.

Os SIGs constituem uma ferramenta importante para a realização de projetos que necessitam de processamentos rápidos e eficientes, de grandes bases de dados, como é o caso dos estudos de fragilidade/vulnerabilidade ambiental, para fins de planos de ordenamento territorial. Nestes estudos é necessária a manipulação de uma grande quantidade de dados vetoriais do meio físico natural e biótico para gerar entre outros produtos, as cartas de vulnerabilidade natural à erosão.

Utilizando o SIG e imagens de satélite para atualizar mapas temáticos é possível se obter uma manipulação ágil e real dos requisitos necessários para satisfazer as condições de geração desse tipo de carta, em que cada um dos parâmetros envolvidos é fundamental e possui valor significativo na avaliação final da fragilidade ambiental. 
Segundo Simões-Meirelles (1997), o principal propósito da maioria dos projetos que utilizam os SIGs como ferramenta é a combinação de dados espaciais advindos de diversas fontes distintas, a fim de descrever e analisar as interações, fazer predições através de modelos e propiciar o suporte necessário para a tomada de decisão.

\section{5 - MODELOS DE FRAGILIDADE/VULNERABILIDADE AMBIENTAL}

Modelos ambientais são representações criadas para simular fenômenos ou processos do mundo real. São representações simplificadas da realidade para facilitar a descrição, a compreensão do funcionamento atual e do desempenho futuro de um sistema. Ou seja, trata-se de um método limitado de representar a natureza.

Felgueiras (1999) expõe que modelos matemáticos, aritméticos e lógicos, buscando representar propriedades e processos do meio físico natural, têm sido implementados, nos SIGs, com o objetivo de facilitar o seu estudo e compreensão para que se possa atuar sobre o meio ambiente de forma responsável e cooperativa.

Modelos computacionais simples são executados diretamente nos SIGs através de operações básicas, lógicas e aritméticas, contidas nos seus módulos de análise ou de álgebra de dados espaciais. Modelos complexos são, muitas vezes, executados fora do ambiente do SIG, por sistemas de modelagem específicos. Nestes casos, os SIGs são usados como base de armazenamento de dados espaciais e também como ferramentas de visualização para os dados de entrada e de saída dos modelos.

Segundo Moore et al. (1993) os modelos ambientais são usados para aumentar o conhecimento sobre um processo, predizer valores ou comportamentos em áreas não observadas e comprovar, ou não, hipóteses feitas sobre processos.

Existem alguns modelos ligados à questão da vulnerabilidade ambiental, os quais se subdividem em dois tipos: qualitativos e quantitativos.

Os modelos quantitativos estimam as variações e perdas de solos, quantificando os fenômenos da erosão. Um das metodologias mais difundidas para a predição de perda de solos é a Equação Universal de Perda de Solos (EUPS). Os modelos qualitativos avaliam o fenômeno da erosão no que diz respeito a sua origem e evolução, os condicionantes e mecanismos que explicam seu surgimento e que atuam no seu desenvolvimento.

Os modelos quantitativos se baseiam em medições e experimentos, e os modelos qualitativos são modelos empíricos que estão baseados na experiência de especialistas.

O foco desta pesquisa está direcionado para os modelos qualitativos, os quais são elaborados por especialistas no assunto e baseados nos seus respectivos conhecimentos e experiências (modelos empíricos).

Nestes modelos os relacionamentos espaciais entre as variáveis de estudo são estimados por critérios estatísticos a partir de amostras de uma região experimental, ou a partir de 
um conjunto de classes, onde a importância (peso) e os limiares destas classes são baseados na experiência de especialistas.

Estes modelos aplicados ao estudo da fragilidade para fins de ordenamento territorial através da inter-relação entre as variáveis (relevo, solo, rocha, clima e uso da terra) resultam num mapeamento síntese em que a área de estudo é classificada segundo uma escala de fragilidades. Estes modelos foram desenvolvidos para subsidiar o planejamento com pressupostos para o desenvolvimento econômico e a conservação do ambiente, visando promover o uso dos recursos naturais da melhor maneira possível.

Destaca-se nesta pesquisa os modelos empíricos propostos por Ross (1994) com base nos Índices de Dissecação do Relevo, e por Crepani et al. (2001) com base em Unidades Territoriais Básicas (UTBs).

Os procedimentos metodológicos utilizados pelos modelos propostos por Ross (op.cit.) e Crepani et al. (op.cit.) partem do mesmo princípio, a ecodinâmica de Tricart (1977), para delimitar áreas no contexto dos diagnósticos ambientais.

Segundo o modelo proposto por Ross (1994) a análise empírica da fragilidade é realizada a partir de produtos cartográficos temáticos de geomorfologia, pedologia, climatologia, uso da terra/cobertura vegetal adotando-se os seguintes procedimentos:

- A carta geomorfológica, juntamente com a análise genética, é um dos produtos intermediários para a construção da carta de fragilidade;

- A carta de solos utiliza os critérios de textura, plasticidade, estrutura, grau de coesão das partículas, profundidade/espessura dos horizontes superficiais e subsuperficiais;

- A carta de uso da terra/cobertura vegetal é outro produto intermediário sendo utilizada para avaliar o grau de proteção dos solos pela vegetação;

- No tocante ao clima, os dados mais importantes são referentes à intensidade e distribuição das chuvas.

Cada uma destas variáveis é hierarquizada em cinco classes de vulnerabilidade, sendo que a correlação entre estes planos de informação estabelece o grau de fragilidade.

Também embasado no conceito de ecodinâmica de Tricart (1977), Crepani et al. (2001) basearam-se na relação morfogênese/pedogênese e no aspecto sinótico fornecido pelas imagens de sensoriamento remoto para propor uma metodologia de análise da vulnerabilidade, adotando os seguintes procedimentos metodológicos:

- Elaboração de um mapa preliminar contendo unidades homogêneas, obtido através da análise e interpretação da imagem de satélite, considerando-se os diferentes padrões identificados pelas cores, texturas, formas, padrão de drenagem e relevo; 
- Associação das variáveis (relevo, solo, rocha, clima e cobertura vegetal/uso da terra) com o mapa preliminar de unidades homogêneas (UTBs) para caracterizar as unidades de paisagem;

- Classificação do grau de vulnerabilidade e estabilidade de cada unidade ambiental expressa pela atribuição de valores de estabilidade (de 1 a 3) para cada unidade ambiental.

Apesar dos dois modelos empíricos partirem do mesmo princípio, a ecodinâmica, apresentam certas diferenças, as quais residem na operacionalização dos métodos, nas variáveis analisadas e nos pesos relativos atribuídos para cada uma das variáveis envolvidas. Conseqüentemente, os resultados apresentados são mapeamentos diferenciados, conforme apresentado em Spörl (2001).

\section{6 - SisteMAS de SUPORTE À DECISÃO}

Os Sistemas de Suporte a Decisão (SSD) são sistemas computacionais que tem por objetivo ajudar os usuários a tomar decisões na solução de problemas, sendo que esse tipo de problema, via de regra, não é facilmente tratável por soluções computacionais. Em conseqüência, a solução destes problemas exige uma interação entre homem e máquina, fato que constitui uma das principais características dos SSD.

A finalidade de um Sistema de Suporte a Decisão não é tomar decisões, mas auxiliar a missão de decidir. Neste caso, este sistema pode dar suporte a questões complexas que envolvem a vulnerabilidade ambiental.

Nesta questão da fragilidade ambiental é fundamental estabelecer como determinada variável interfere neste processo. Cada variável contribui com uma intensidade diferenciada na composição do grau de vulnerabilidade do sistema. Ou seja, as variáveis apresentam diferentes "pesos" (graus de intensidade) os quais devem indicar sua contribuição relativa na determinação do grau de fragilidade. Por se tratar dos fenômenos complexos da natureza esta avaliação é, geralmente, arbitrária e subjetiva.

A atribuição de pesos às variáveis para a identificação dos graus de vulnerabilidade é uma das grandes dificuldades da operacionalização dos modelos. Esta tarefa é altamente qualitativa e carregada de subjetivismo, ficando muitas vezes a mercê da impressão do especialista.

Este problema caracteriza-se pela complexidade advinda do número de variáveis envolvidas, as suas inter-relações e as incertezas e ambigüidades associadas às mensurações destas mesmas variáveis e à forma pela qual devem ser combinadas. Segundo Eastman et al. (1995), nos últimos anos, esforços têm sido despendidos no sentido de se desenvolver técnicas e procedimentos conjugados com SIGs para equacionar decisões envolvendo múltiplos critérios e objetivos. 
Segundo Rafaeli Neto (2000) tendo em vista a complexidade de tais problemas e a necessidade de soluções de qualidade o especialista precisa contar com métodos, técnicas e tecnologias de suporte.

Utilizar instrumentos eficientes para a determinação dos graus de fragilidade possibilita a tomada de decisão mais segura. Ruhoff et al. (2005) constatam que atualmente existem várias técnicas de suporte a decisão envolvendo a inferência espacial para a integração de dados de natureza geográfica, dentre os quais podem ser destacados os modelos Booleano, Média Ponderada, Processo Analítico Hierárquico (AHP), Bayesiano e Redes Neurais Artificiais (RNAs).

O uso destas técnicas, segundo Openshaw e Openshaw (1997), auxilia a solução de problemas em geografia. Estas técnicas podem ser utilizadas para buscar e revelar padrões escondidos em grandes conjuntos de dados derivados de problemas em geografia física ou humana, e em particular, métodos não convencionais para análise de agrupamentos.

Neste sentido, a combinação das técnicas de avaliação sob critérios múltiplos, a definição de critérios e pesos, as tecnologias de sensoriamento remoto e sistema de informações geográficas com a participação de especialistas no processo de decisão podem oferecer um instrumento integrado visando dar suporte e aperfeiçoar as técnicas para a determinação dos graus de fragilidades e potencialidades.

\subsection{1 - Processo Analítico Hierárquico}

Quando há diferentes fatores que contribuem para a decisão, como fazer para determinar a contribuição relativa de cada um, ou seja, como definir seus pesos? Embora exista uma variedade de técnicas para a definição de pesos, Eastman et al. (1995) descrevem a técnica do Processo Analítico Hierárquico (Analytical Hierarchy Process AHP), desenvolvida por Saaty (1992), como sendo a mais promissora no contexto do processo de tomada de decisão.

Trata-se de uma técnica com base matemática que permite organizar e avaliar a importância relativa entre critérios e medir a consistência dos julgamentos. É um método de escolha baseada na lógica da comparação pareada. Neste procedimento diferentes fatores que influenciam a tomada de decisão são comparados dois-a-dois, e um critério de importância relativa é atribuído ao relacionamento entre estes fatores.

Segundo Câmara et al. (2001) através da comparação pareada é possível organizar e avaliar a importância relativa entre as variáveis ambientais e medir a consistência dos julgamentos. Esta metodologia caracteriza-se por ser um processo interativo e intuitivo que permite avaliações, sejam elas objetivas e/ou subjetivas, além de possuir como principal característica uma estrutura hierárquica que subdivide o problema em níveis do mais complexo ao mais simples, permitindo uma visão mais clara e ampla, objetivando a avaliação de diversas linhas de ação, com o intuito de ordená-las ao final, em função do objetivo global estabelecido. 
De acordo com Schmidt (1995) o ingrediente principal que tem levado as aplicações com o AHP (Analytical Hierarchy Process) a terem sucesso é o poder de incluir e medir fatores importantes, qualitativos e/ou quantitativos, sejam eles, tangíveis ou intangíveis, e a facilidade de uso.

Existe um grande número de aplicações para a AHP (Analytical Hierarchy Process) em diversas áreas do conhecimento. Podem ser citados alguns trabalhos que utilizaram essa técnica, assim como, zoneamento, vulnerabilidade ambiental, prospecção mineral, seleção de áreas para disposição de resíduos, potencial de risco à ocupação, risco de movimentos de massa ou impacto ambiental, suscetibilidade aos escorregamentos, etc.

O método AHP (Analytical Hierarchy Process) tem sido aplicado em vários campos da ciência mediante a consulta de especialistas no assunto em questão.

\subsection{2 - Redes Neurais Artificiais (RNAs)}

A Inteligência Artificial (IA) pode ser definida como um conjunto de modelos, algoritmos, técnicas, ferramentas e aplicações, em um sistema computadorizado, que emula alguma das habilidades cognitivas do homem. Com o desenvolvimento da IA surge a idéia de representar por meio de determinados programas computacionais o funcionamento do processo de aprendizagem do cérebro humano.

Neurologistas, juntamente com pesquisadores de outras áreas, tais como a eletrônica, automação, biofísica, matemática desejavam produzir um modelo que descrevesse a rede neural biológica. Por volta de 1943, Mac-Culloch e Pitts apresentaram um modelo básico de neurônio, que era ao mesmo tempo simples e poderoso. Estes autores tiveram grande importância pois foram os primeiros pesquisadores a tratar o cérebro como um "organismo computacional".

Neste contexto a tentativa de simular a rede neural do cérebro deu origem à rede neural artificial (RNA). Que de acordo com Braga et al. (2000) as RNAs são modelos matemáticos que se assemelham às estruturas neurais biológicas e possuem a capacidade de aprender por meio de exemplos e de generalizar a informação aprendida, gerando um modelo não linear.

Segundo Carvalho et al. (1998) a solução de problemas com RNAs passa inicialmente por uma fase de aprendizagem, onde um conjunto de exemplos é apresentado para a rede, que extrai automaticamente as informações necessárias para representar a informação fornecida. Essas características são utilizadas posteriormente para gerar respostas para o problema.

Segundo Sarmento (1996) as RNAs devem ser utilizadas na modelagem de fenômenos naturais nos casos para os quais não se dispõem de uma formulação matemática explícita, capaz de reproduzir as relações entre as diversas variáveis envolvidas. 
Openshaw e Openshaw (1997) constatam que as redes neurais são importantes ferramentas na aplicação para modelagem, simulação, reconhecimento de padrões e séries temporais.

Numerosos avanços foram obtidos nos últimos anos no desenvolvimento de sistemas inteligentes, principalmente no que diz respeito às RNAs. Pesquisadores das mais diversas áreas têm as utilizado para a solução dos mais diversos tipos de problemas. Entre esses, destacam-se aqueles que envolvem o controle de sistemas complexos onde o comportamento das variáveis não é rigorosamente conhecido.

As RNAs são utilizadas nas mais diversas áreas do conhecimento, principalmente em aplicações que envolvam o reconhecimento de padrões. Pode-se citar como exemplos mais comuns, o reconhecimento de padrões em imagens, análise de séries temporais, processamento de voz, diagnósticos médicos, previsões no mercado financeiro, etc.

$\mathrm{Na}$ análise espacial, o uso de RNAs intensificou-se a partir dos anos 90, segundo Openshaw e Openshaw (1997). Desde então, muitos trabalhos surgiram na literatura, tratando de temas diversos, como: classificação de imagens de sensores remotos (JI, 2000; VILLMANN et al., 2003); predição dos níveis de pluviosidade (LEE et al., 1998); previsão de cheia (OPENSHAW et al. 1998); relação chuva-vazão (SARMENTO, 1996); determinação dos índices de vulnerabilidade à erosão (MEDEIROS, 1999); produção de mapas potenciais para diversos bens minerais (NOBREGA, 2001); na solução de problemas geotécnicos (SANTO JR, 2006); e para avaliação de erosão em áreas agrícolas (ROSA et al., 1999).

Recentemente vários trabalhos têm demonstrado o excelente desempenho das RNAs na aplicação de estudos ligados a questão ambiental.

Chagas et al. (2007) utilizaram redes neurais artificiais para predição de classes de solos, utilizando como fonte de dados sensores remotos orbitais e atributos do terreno derivados de um modelo digital de elevação (MDE), em uma região montanhosa no Noroeste Fluminense. A comparação com pontos de referência obtidos em campo mostrou que o mapa produzido pelas RNAs teve um desempenho melhor do que a abordagem convencional, mostrando um melhor nível de detalhamento. Concluíram então que as RNAs podem contribuir para tornar o mapeamento de solos no Brasil mais quantitativo e confiável.

No trabalho desenvolvido por Moreira et al. (2006) utilizaram a RNA como método de interpolação para obter estimativas do valor da erosividade da chuva (R) para localidades onde este é desconhecido. Comparando a RNA desenvolvida com o método de interpolação "Inverso de uma Potência da Distância" (ID), verificou-se que a primeira apresentou menor erro relativo médio na estimativa de $\mathrm{R}$ e melhor índice de confiança, classificado como "Ótimo", podendo, portanto, ser utilizada no planejamento de uso, manejo e conservação do solo no Estado de São Paulo. 
Medeiros (1999) comparou o modelo de avaliação de vulnerabilidade ambiental proposto por Crepani et al. (1996) com um modelo que utilizou a RNA treinada com dados gerados pela álgebra de mapas. Conclui que:

A RNA adequadamente treinada pode complementar, ou até mesmo, substituir outras técnicas de análise geográfica utilizadas nos SIGs, pelo menos, com relação ao modelo de avaliação da vulnerabilidade natural à erosão proposto por Crepani et al. (1996).

O método das RNAs oferece também uma abordagem vantajosa à questão da fragilidade, pois essas redes representam um sistema computacional adaptativo que pode aprender, ou adquirir conhecimento a partir dos dados através de técnicas de inteligência artificial. Segundo Brown et al. (2000) as redes neurais possuem algumas propriedades que as tornam adequadas ao reconhecimento de padrões e à classificação de dados espaciais, entre as quais:

- habilidade em extrair padrões ocultos em conjuntos de dados que podem ser imperceptíveis aos humanos e às técnicas estatísticas tradicionais;

- capacidade de analisar dados sem nenhum conhecimento prévio;

- possibilidade de trabalhar com dados ruidosos, limitados, interdependentes ou não-lineares;

- possibilidade de adição continua de novos dados;

- facilidade para a análise de grandes conjuntos de dados.

Nesse sentido a proposta de utilizar redes neurais artificiais nos modelos de fragilidade ambiental é oferecer uma alternativa para decisões complexas, envolvendo muitos critérios, sendo que a seleção dos critérios, bem como a definição dos pesos, tratam-se de avaliações arbitrárias e subjetivas, dificultando o processo de tomada de decisão. 


\section{3 - ÁREA DE ESTUDO}

Uma vez definido o caminho metodológico é necessária sua aplicação num estudo de caso, de forma a aferir sua capacidade de responder as premissas levantadas. Salienta-se que, para tanto, é necessária a definição de uma área de estudo e a existência de uma base de dados consistente. Neste sentido, foram selecionadas duas áreas-teste distribuídas pelo estado de São Paulo, conforme apresentado na Figura 3.1.

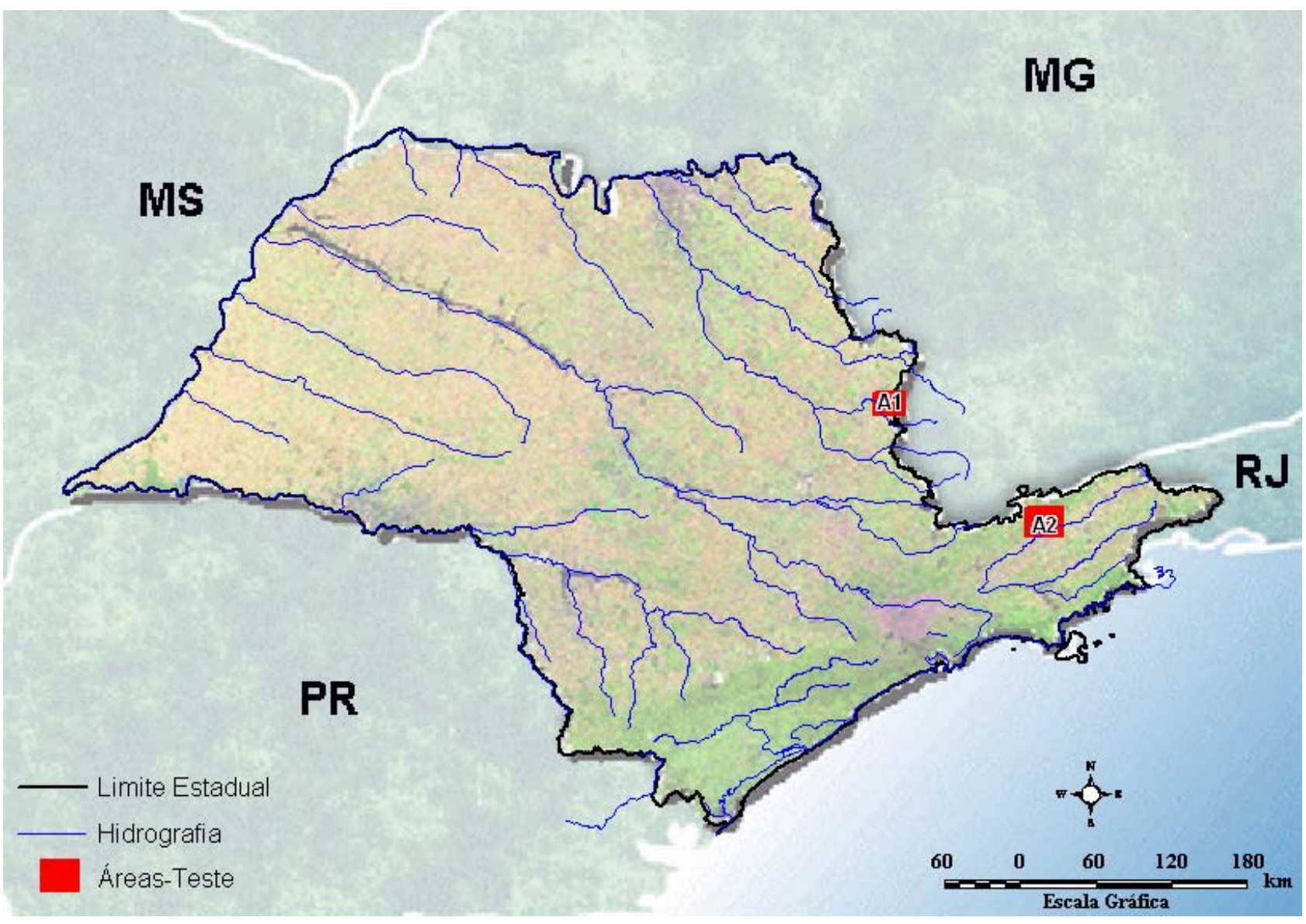

Figura 3.1 - Localização das áreas-teste

Estas áreas-teste foram selecionadas em função de suas diferentes características físicas e bióticas, principalmente pela grande variabilidade do relevo. Só assim será possível testar a capacidade preditiva dos modelos em diferentes cenários.

\section{1 - ÁREA-TESTE 1}

A Área-teste 1situa-se a nordeste do Estado de São Paulo e ao sul do Estado de Minas Gerais. Está delimitada por um quadrilátero entre as coordenadas geográficas 46 36 $26^{\prime \prime}$ e $46^{\circ} 50^{\prime} 18^{\prime \prime}$ de longitude oeste e $21^{\circ} 50^{\prime} 21^{\prime \prime}$ e $22^{\circ} 01^{\prime} 07^{\prime \prime}$ de latitude sul. Este quadrilátero está extrapolando os limites das bacias hidrográficas dos Ribeirões do Quartel e da Prata e do Rio Jaguari-Mirim para uma melhor espacialização da geomorfologia além divisores d'água. 
Esta área ocupa aproximadamente $480 \mathrm{Km}^{2}$, englobando terras dos municípios de Águas da Prata (SP), São João da Boa Vista (SP), pequena faixa de Vargem Grande do Sul (SP) e parte do município de Poços de Caldas (MG), conforme apresentado na Figura 3.2.

Esta área enquadra-se numa zona de transição entre as terras altas do Planalto Atlântico (terrenos cristalinos) do sudoeste mineiro e a região rebaixada (sedimentares) nas proximidades da Depressão Periférica Paulista.

As altitudes variam entre 680 e 1620 metros, o mapa hipsométrico deixa claras as diversidades morfométricas observadas de oeste para leste. É nítida a presença de uma topografia pouco dissecada no oeste, que progressivamente, vai alterando suas feições para leste da área de estudo, conforme ilustra a Figura 3.3.

Esta região pode ser subdividida em três compartimentos distintos, com características próprias de relevo, solo, litologia, vegetação e uso da terra. Estes compartimentos, as unidades de paisagem, podem ser assim delimitados: Planalto de Poços de Caldas, Planalto de São João da Boa Vista - Águas da Prata e Serras da Borda do Maciço Intrusivo de Poços de Caldas, como identificado na Figura 3.2.

As condições climáticas da Área-teste 1 refletem a existência de um clima tropical, progressivamente influenciado pelas altitudes. Adotando-se a classificação de Köppen, a região pode ser dividida em dois subtipos pelas influências locais do relevo: Cwa e Cwb, caracterizando-se como climas tropicais de altitude com concentração de chuvas no verão (dezembro a março) e períodos secos no inverno (junho a agosto). A precipitação média anual varia de 1400 a $2000 \mathrm{~mm}$.

O subtipo climático Cwb diferencia-se do Cwa por apresentar maiores valores pluviométricos e menores valores térmicos, ou seja, ele é mais úmido e menos quente que o Cwa. O Cwb ocorre no Planalto de Poços de Caldas e nas partes mais elevadas das zonas das serras, já o subtipo Cwa, abrange o Planalto de São João da Boa Vista - Águas da Prata e as zonas mais rebaixadas das serras.

Os Gráficos 3.1 e 3.2 apresentam os totais pluviométricos dos postos localizados na Serras da Borda do Maciço Intrusivo de Poços de Caldas e no Planalto de São João da Boa VistaÁguas da Prata, respectivamente, para o ano de 1999 (data mais recente com dados consistentes para a comparação dos dois postos). 


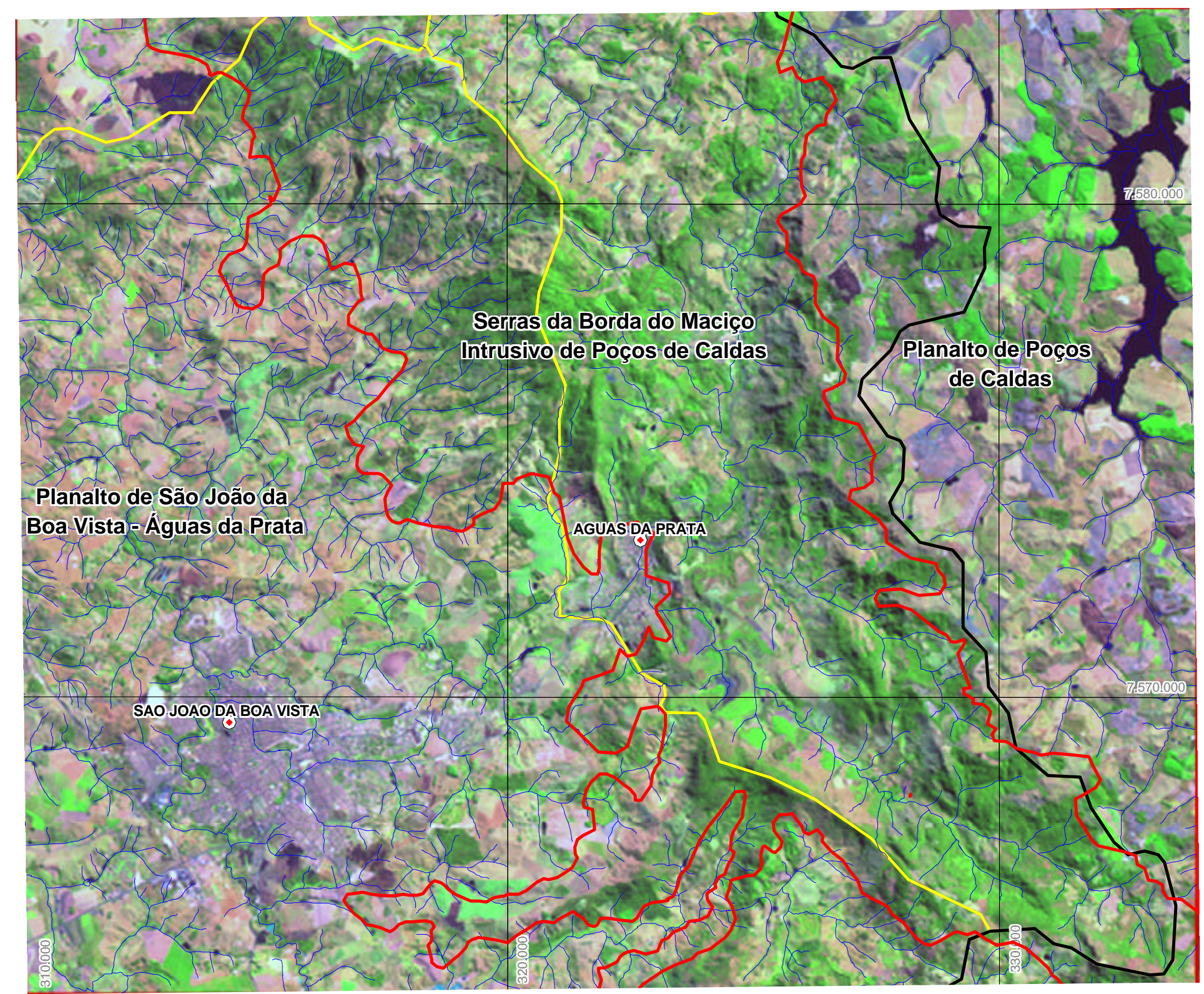

\section{FIGURA 3.2 - LOCALIZAÇÃO ÁREA-TESTE 1}

Hidrografia

- Sede Municipal

Limite Municipal

_ Limite Estadual

_ Unidades de Paisagem
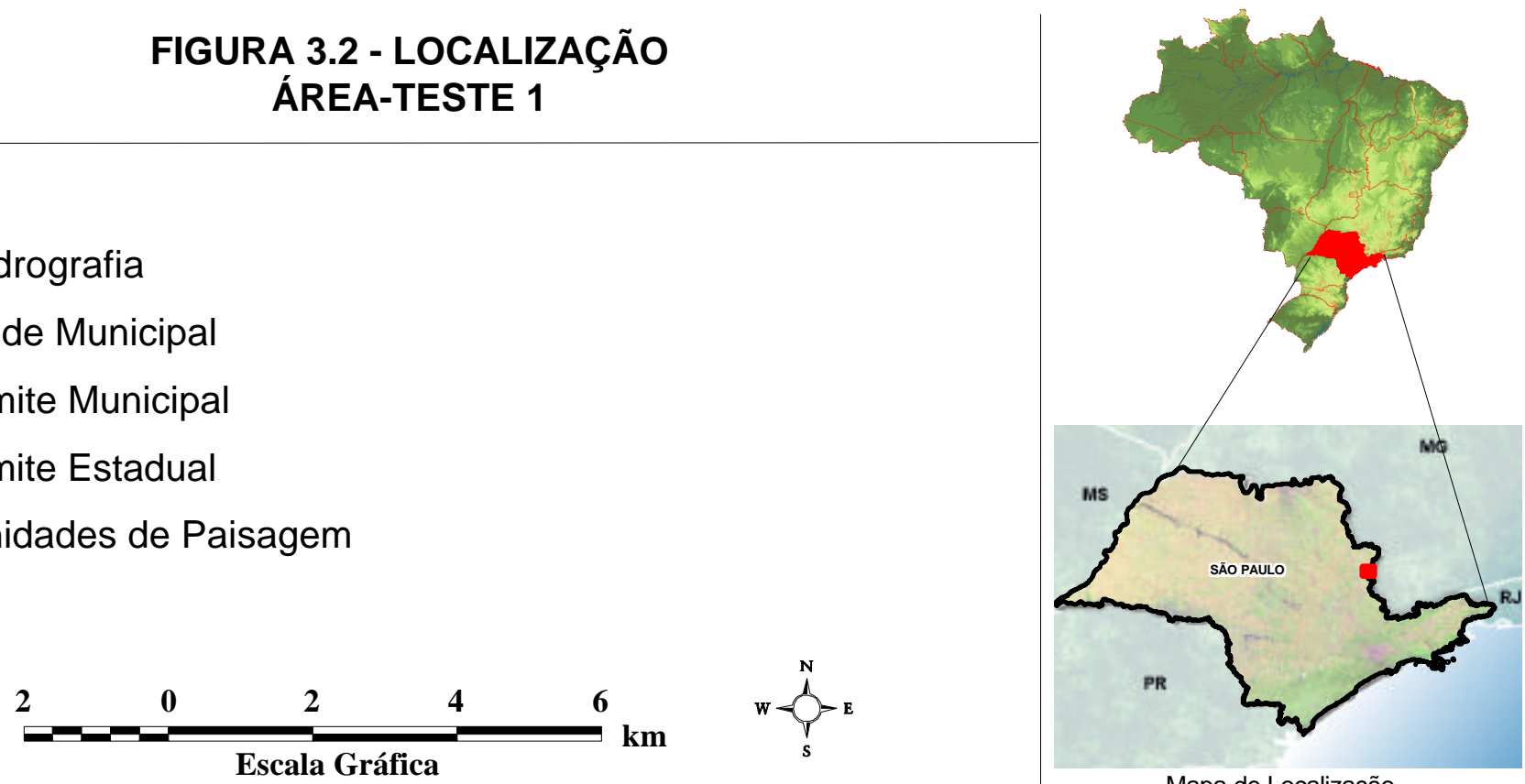

Mapa de Localização 


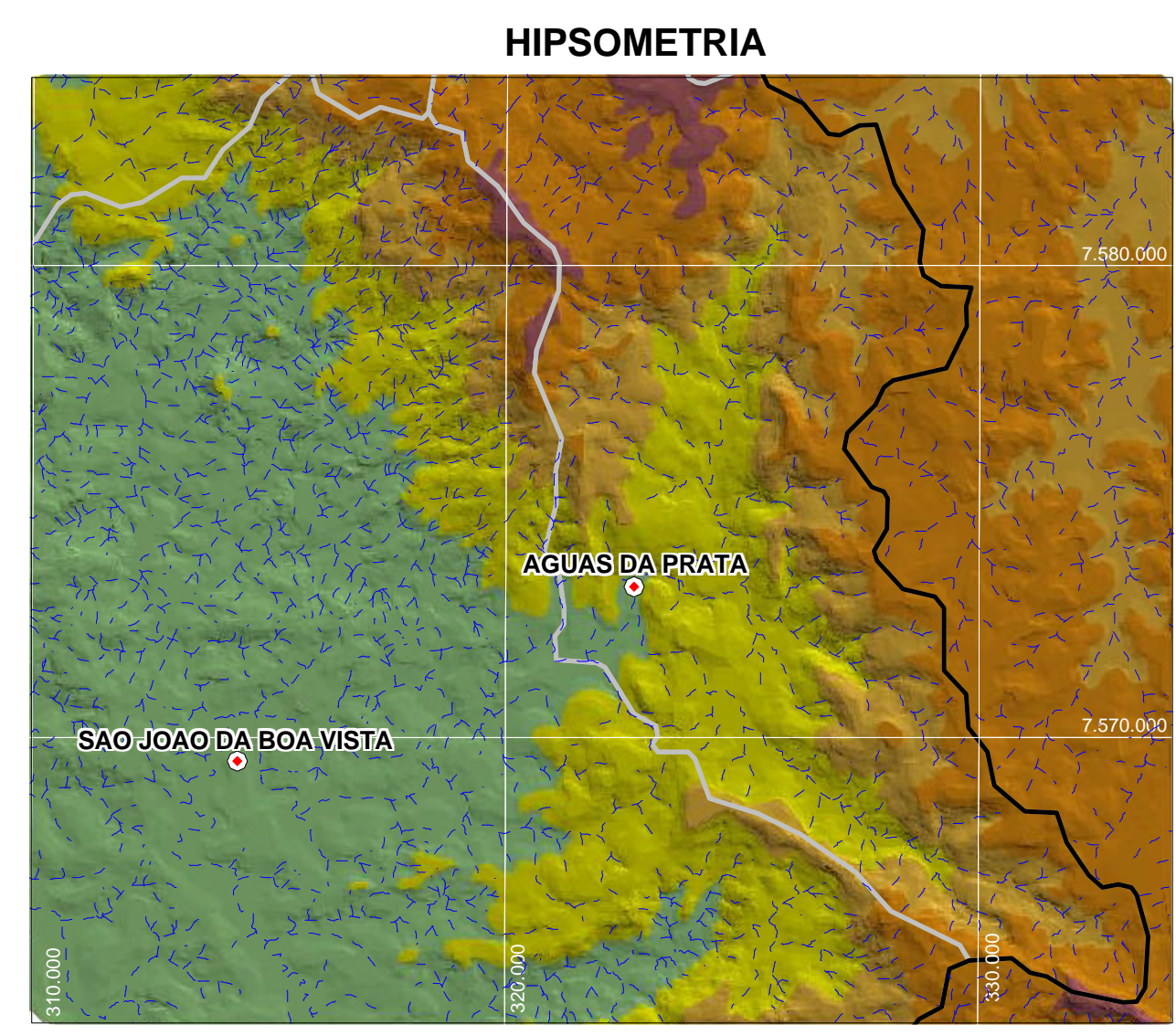

\section{Hipsometria}

< que $550 \mathrm{~m}$ De 550 a $650 \mathrm{~m}$ De 650 a $850 \mathrm{~m}$ De 850 a $1100 \mathrm{~m}$ De 1100 a $1300 \mathrm{~m}$ De 1300 a $1500 \mathrm{~m}$ De 1500 a $1700 \mathrm{~m}$ > que $1700 \mathrm{~m}$
- Sede Municipal

_ Limite Municipal

— Limite Estadual

- . Hidrografia

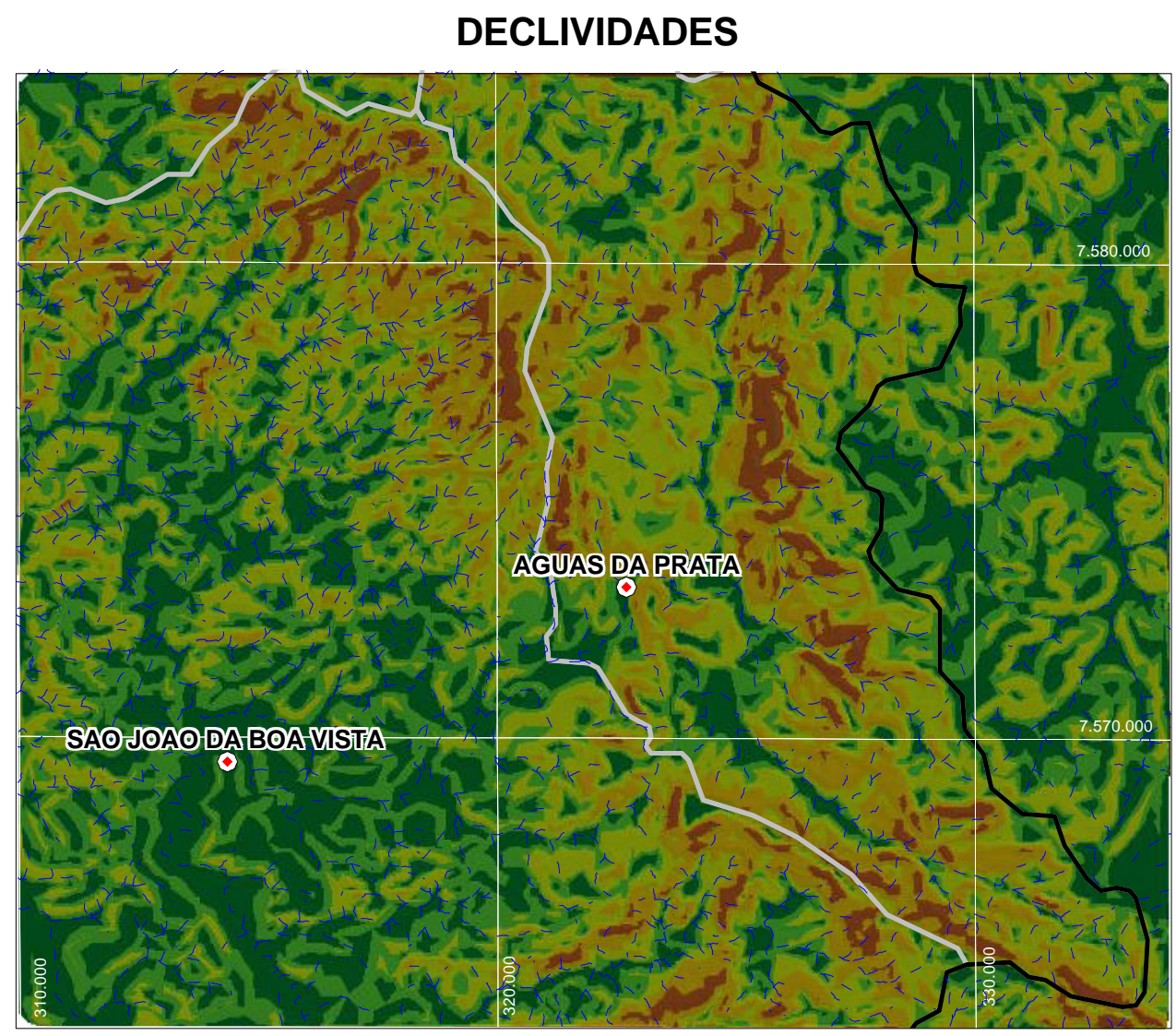

\section{Classes de Declividade}
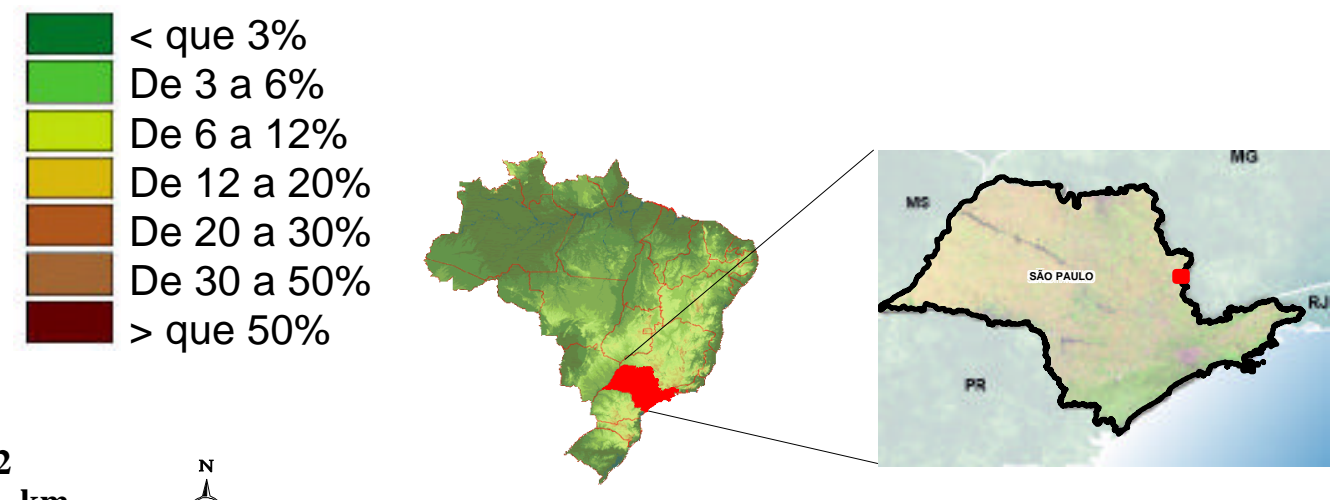

FIGURA 3.3 - HIPSOMETRIA E DECLIVIDADES DA ÁREA-TESTE 1 


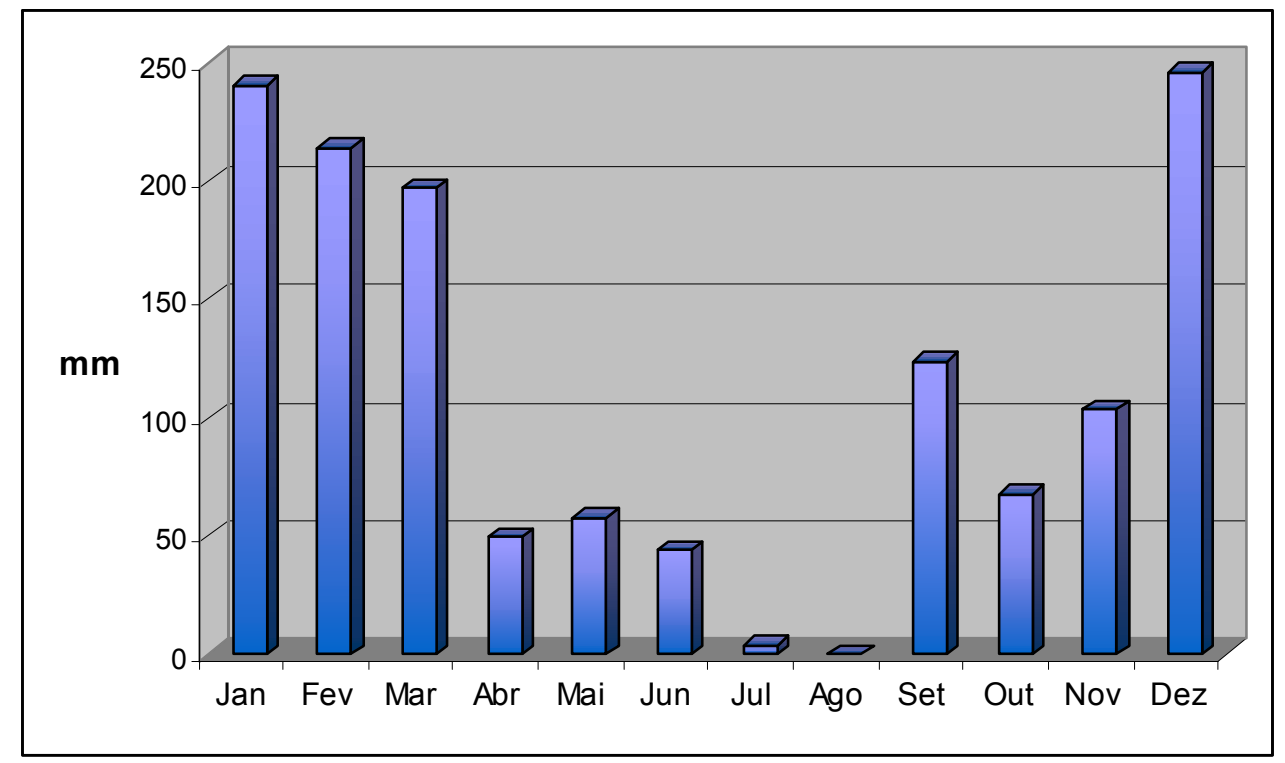

Gráfico 3.1 - Totais pluviométricos do posto C3-034 localizado em Água da Prata, para o ano de 1999 - (Fonte: DAEE)

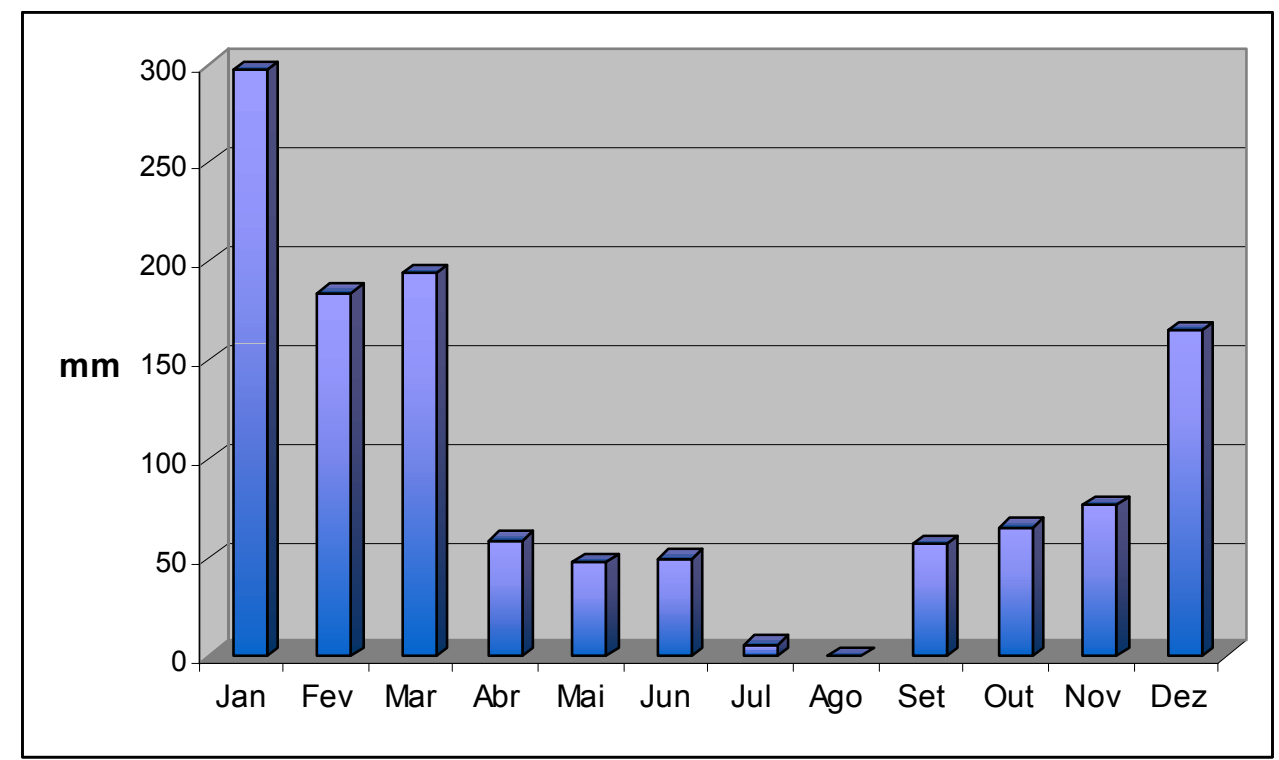

Gráfico 3.2 - Totais pluviométricos do posto C3-031 localizado em São João da Boa Vista, para o ano de 1999 - (Fonte: DAEE)

\subsection{1 - Planalto de São João da Boa Vista - Águas da Prata}

Este compartimento, localizado a leste do Ribeirão dos Porcos até os contrafortes das serras da Fartura e da Cachoeira, apresenta uma altimetria que varia entre 680 e 900 metros, e declividades que variam entre 3 e $30 \%$.

Esta área está constituída pelas rochas do complexo cristalino representadas principalmente por granitos e gnaisses, conforme apresentado na Figura 3.4. 


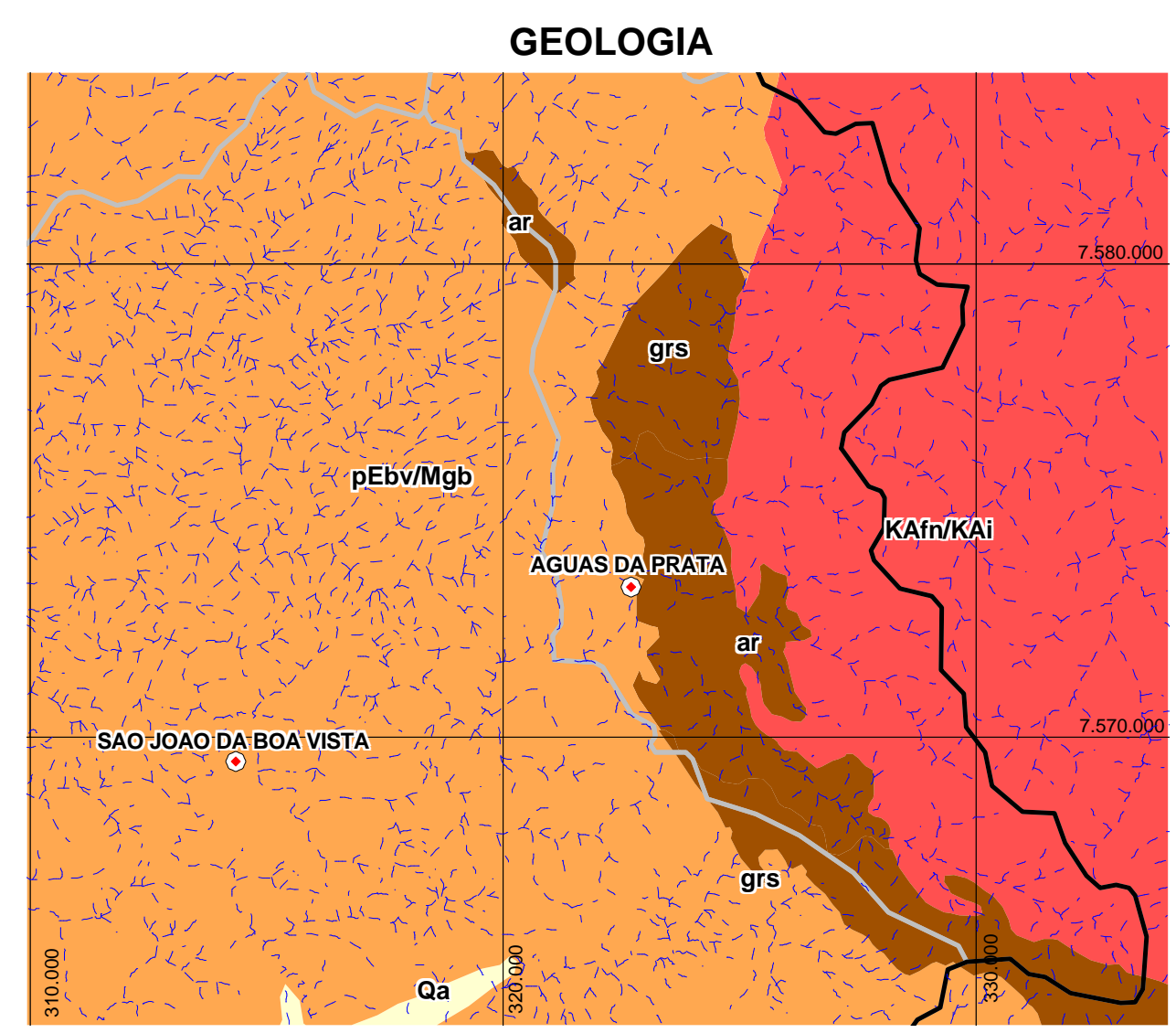

\section{Geologia}

Formação Botucatu

Embasamento Cristalino

Depósitos Aluviais

Maciço Alcalino de Poços de Caldas

- Sede Municipal

Limite Municipal

_ Limite Estadual

- - Hidrografia

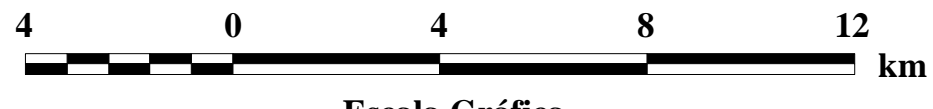

Escala Gráfica

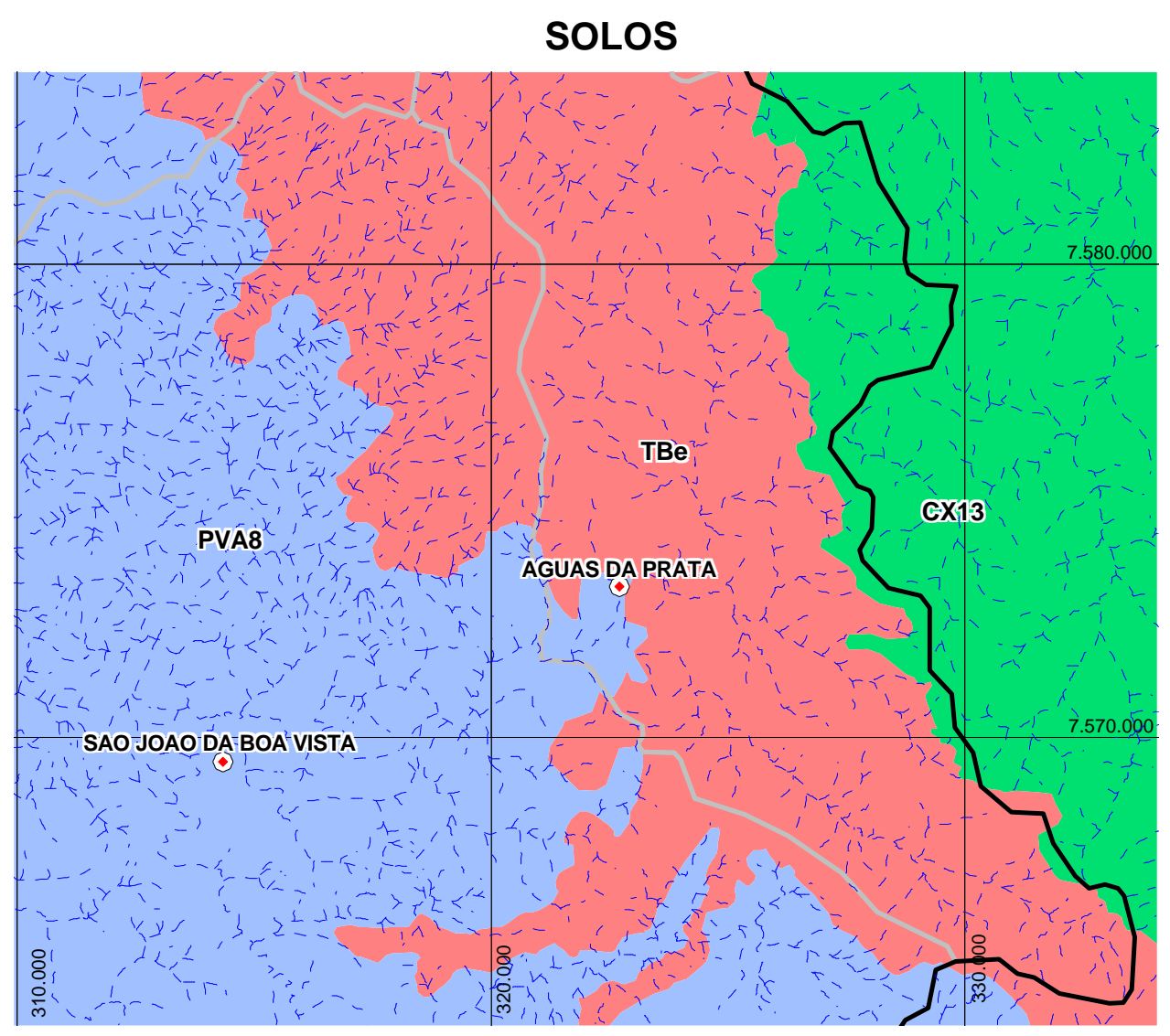

\section{Solos}

Argissolos Vermelho-Amarelos

Cambissolos Háplicos

Nitossolos

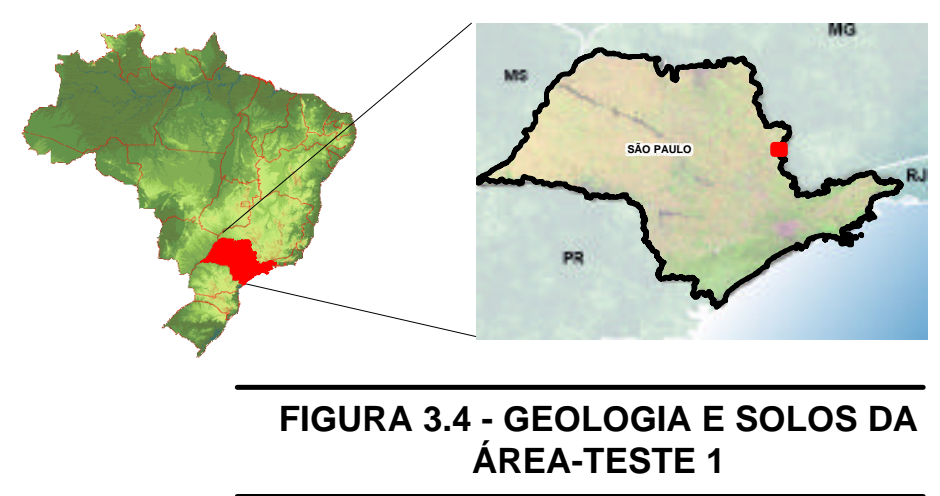


Os solos predominantes são os Argissolos Vermelho-Amarelos, situados em áreas de relevo predominantemente ondulado e montanhoso. São solos minerais com horizonte $B$ textural, não hidromórfico, normalmente com argila de atividade baixa, usualmente profundos, com seqüência de horizontes A, B, e C, sendo bem a moderadamente drenados.

A textura do horizonte A é arenosa ou média, e em alguns casos argilosa, já o horizonte B textural é franco-arenoso ou mais fina, ocorrendo também solos com mudança textural abrupta.

Nesta região, de setores rebaixados dos terrenos cristalinos, as formações florestais já foram praticamente toda destruída, restando alguns vestígios, apenas nas partes altas de morros mais salientes, onde o declive é muito acentuado.

Esta região, assim como na maior parte do Estado de São Paulo, teve sua vegetação original destruída em conseqüência do surto cafeeiro. Atualmente, grande parte destes cafezais foram abandonados ou deram origem a pastos.

Hoje em dia a área tem um uso predominantemente destinado às pastagens, ocorrendo ainda algumas áreas dedicadas ao cultivo de café, e em menor escala, à batata e cebola, conforme apresentado na Figura 3.5 e nas Fotos 3.1 e 3.2.

\subsection{2 - Serras da Borda do Maciço Intrusivo de Poços de Caldas}

As Serras da Borda do Maciço Intrusivo de Poços de Caldas apresentam vertentes bastante inclinadas com declividades, às vezes, superiores a 50\%. As altitudes variam entre 680 e 1620 metros, registrando-se em certos locais desníveis abruptos, que definem verdadeiras escarpas, profundamente dissecadas, como na Serra da Fartura, a NNE de São João da Boa Vista.

Os vales são predominantemente em $\mathrm{V}$ e, cada vez mais fechados à medida que se avança para montante até atingir o divisor d'água mais saliente que é a Serra da Fartura, superando a cota de 1500 metros.

Neste compartimento ocorrem rochas alcalinas e sedimentos identificados como arenitos Botucatu, além das rochas do complexo cristalino representada, principalmente, por granitos e gnaisses.

Os solos predominantes nesta área de relevo muito dissecado são os Nitossolos associados ao Neossolos Litólicos. 


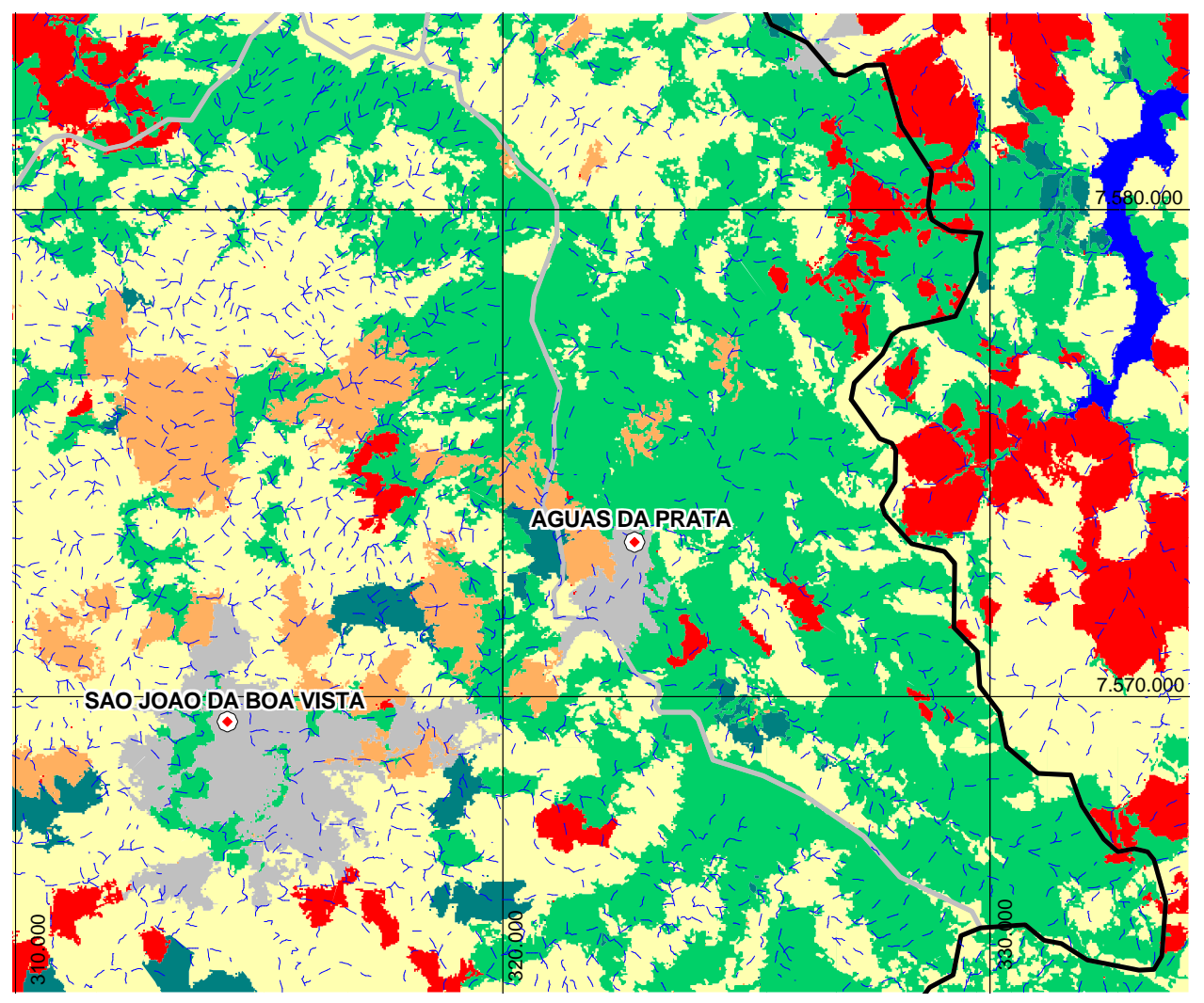

\section{Uso e Ocupação da Terra}

Agricultura Ciclo Curto Área Urbana

Café

Corpos d’água

Mata

Pastagem

Reflorestamento
- Sede Municipal

- Limite Municipal

_ Limite Estadual

- - Hidrografia

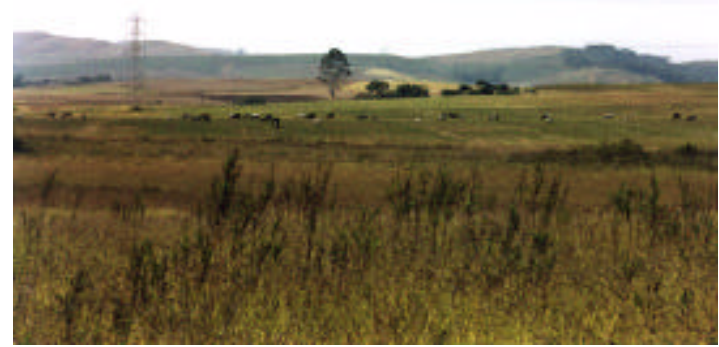

Foto 3.1 - Pastagens no Planalto de São João da Boa Vista-Águas da Prata

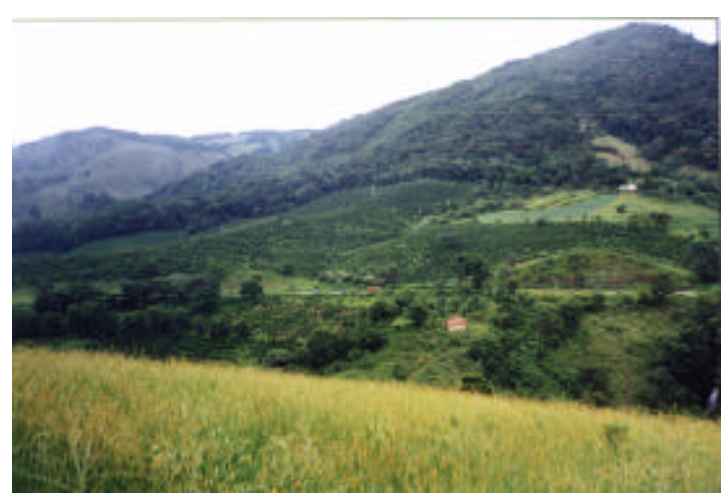

Foto 3.3 - Formações florestais nas escarpas íngremes da região serrana e na média encosta cultivo de café

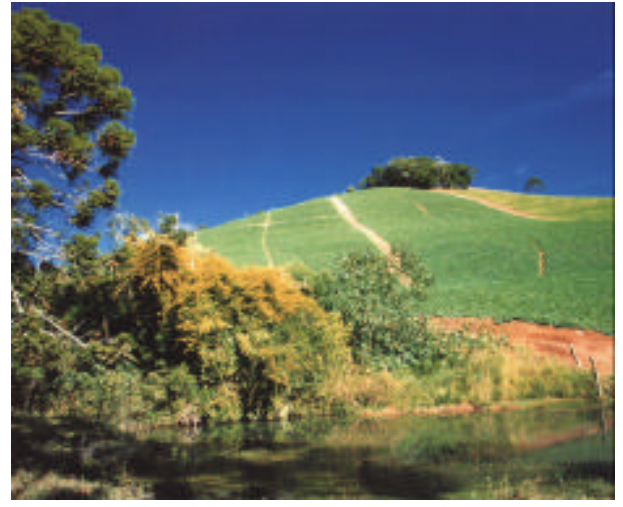

Foto 3.2 - Cultivo de batata em São João da Boa Vista

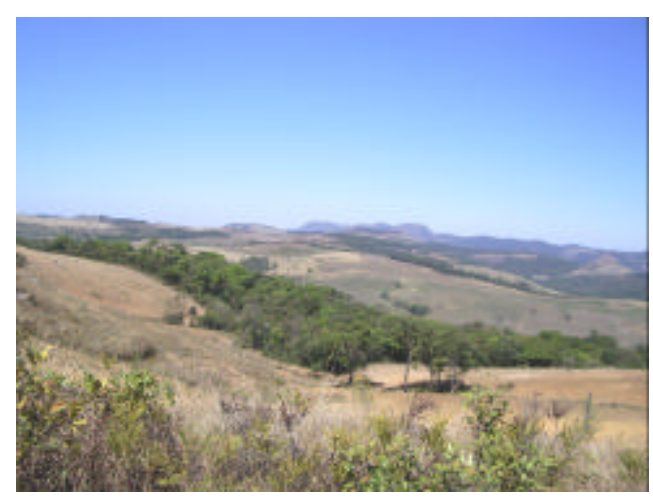

Foto 3.4 - Formações campestres do Planalto de Poços de Caldas
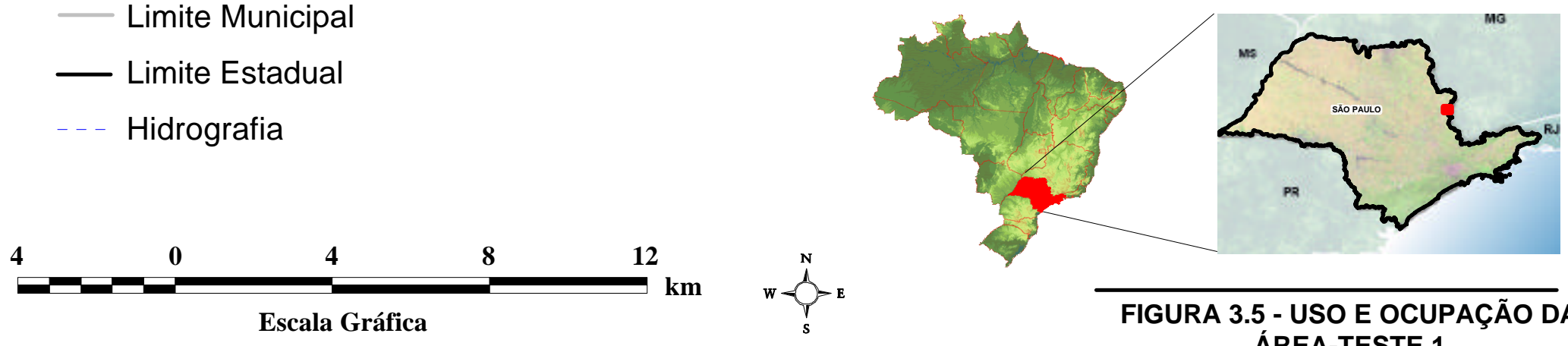

FIGURA 3.5 - USO E OCUPAÇÃO DA ÁREA-TESTE 1 
Os Neossolos Litólicos são originados do produto da decomposição de diferentes tipos de rochas, assim como, quartzito, xistos, argilitos, charnockitos, migmatitos e rochas alcalinas. Compreendem solos minerais, pouco desenvolvidos, com aproximadamente 20 a $40 \mathrm{~cm}$ de profundidade, abrangendo desde solos com horizonte A assentado diretamente sobre camada rochosa até solos com horizonte B relativamente desenvolvido, porém pouco espesso.

Os Nitossolos são dominantemente desenvolvidos de rochas alcalinas, compreendem solos minerais, não hidromórficos, com horizonte B textural e argila de atividade baixa. São solos bem drenados, profundos, de textura muito argilosa.

As características físicas destes solos tornam difícil seu uso. Os Nitossolos por apresentarem pedregosidade na superfície e grande susceptibilidade à erosão, e os Neossolos Litólicos por apresentarem uma baixa fertilidade natural.

As raras e esparsas manchas remanescentes da vegetal original estão concentradas nas escarpas mais íngremes destas regiões serranas, formando um arco em torno do Planalto de Poços de Caldas, na maior parte das vezes, em terrenos de baixa capacidade de utilização agro-pastorial, íngremes, rochosos, ou de baixa fertilidade, conforme apresentado na Figura 3.5 e na Foto 3.3.

Segundo Abreu (1972), as formações florestais recobrem nos terrenos graníticos-gnáissicos desta região, apresentando uma zonação de altitude bastante nítida, diferenciada por uma formação tropical de altitude com araucárias, característica do reverso da Serra da Fartura.

As áreas menos dissecadas têm como fator limitante a utilização agrícola pela sua baixa fertilidade dos solos, sendo portanto, ocupadas principalmente por pastagem natural.

\subsection{3 - Planalto de Poços de Caldas}

Este setor voltado mais a leste da Área-teste 1 é constituído pelo reverso da Serra da Fartura e a porção ocidental do Planalto de Poços de Caldas, delimitados por vertentes abruptas, onde se encontram as Serras da Cachoeira e do Quartel. Transpostas estas escarpas encontram-se trechos menos dissecados, de topografia ondulada, com cotas acima de 1000 metros.

Nesta área está localizado um dos maiores centros ígneos alcalinos, ricos em rochas nefelínicas do mundo, o Complexo Poços de Caldas.

O Complexo Alcalino de Poços de Caldas, de idade mesozóica, é integrado por uma associação variada de rochas alcalinas plutônicas, hipo-abissais, efusivas e piroclásticas. Segundo Radambrasil (1983):

Este Complexo encontra-se encaixado entre granitos e gnaisses de idades pré-cambrianas, os quais nos bordos sudeste e noroeste foram 
afetados por processo de fenitização. Sedimentos argilosos e arenosos, de idade respectivamente permiana e triássica, pertencentes à Bacia do Paraná, acham-se ainda preservados nas bordas oeste e sul do Complexo.

Os solos predominantes desta unidade de paisagem são os Cambissolos Háplico, os quais compreendem solos minerais com horizonte B câmbico ou incipiente, não hidromórficos e com pouca diferenciação de textura do horizonte $A$ para o B. Possuem textura média ou argilosa, com ocorrência de textura muito argilosa, são bem a moderadamente drenados e rasos a profundos. São álicos na grande maioria, com saturação de alumínio maior que $50 \%$, seguido pelos distróficos.

De modo geral, os cambissolos não são utilizados agricolamente por apresentarem como fator limitante ora o relevo acentuado ora o excesso de alumínio. É, portanto, recomendado como uso mais adequado à pecuária extensiva e a silvicultura.

O Planalto de Poços de Caldas apresenta uma paisagem campestre constituída por gramíneas de pequeno porte. Estas formações campestres apresentam-se menos alteradas pela ação antrópica, o que se justifica pela baixa fertilidade dos solos. No entanto, estes campos apresentam hoje aspecto bastante degradado em relação a sua composição e fisionomia originais pela utilização como pastagens, como apresentado na Foto 3.4.

Atualmente está área é dominada pelas pastagens, sendo também de certa expressão as áreas destinadas ao café e à agricultura de ciclo curto, principalmente com cultivo da batata e da cebola.

\section{2 - ÁREA-TESTE 2}

\subsection{1 - Localização}

A Área-Teste 2 situa-se a sudeste do Estado de São Paulo próximo a divisa com Minas Gerais. Está delimitada por um quadrilátero entre as coordenadas geográficas $45^{\circ} 23^{\prime} 23^{\prime \prime} \mathrm{e}$ $45^{\circ} 40^{\prime} 37^{\prime \prime}$ de longitude oeste e $22^{\circ} 44^{\prime} 56^{\prime \prime}$ e $22^{\circ} 58^{\prime} 03^{\prime \prime}$ de latitude sul.

Do ponto de vista da superfície temos aqui um espaço ocupando aproximadamente 445 $\mathrm{Km}^{2}$, abrangendo terras dos municípios de Campos do Jordão, Monteiro Lobato, Santo Antônio do Pinhal, São Bento do Sapucaí, Pindamonhangaba e Tremembé, conforme apresentado na Figura 3.6. 


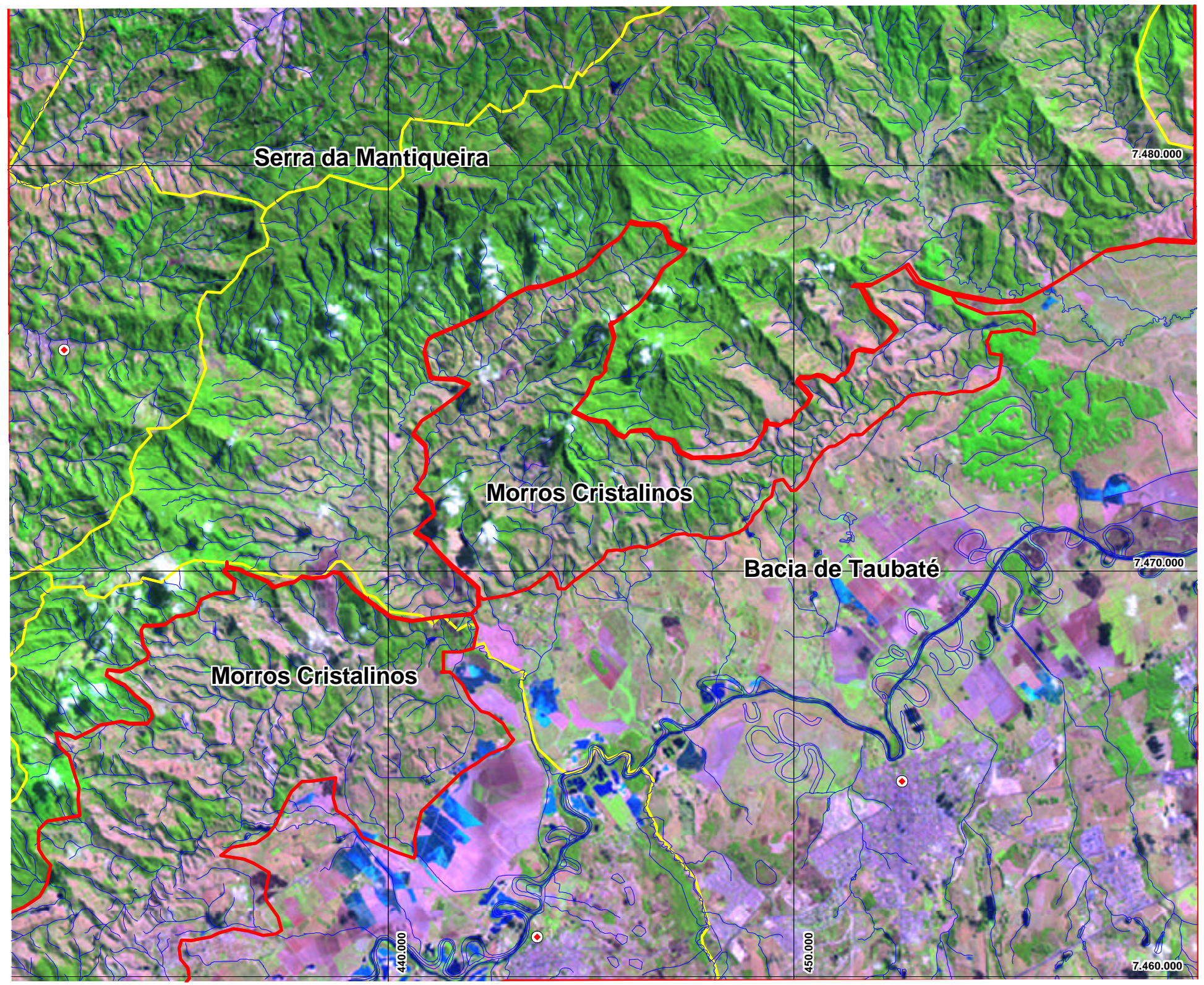

FIGURA 3.6 - LOCALIZAÇÃO ÁREA-TESTE 2

Hidrografia

- Sede Municipal

Limite Municipal

— Unidades de Paisagem

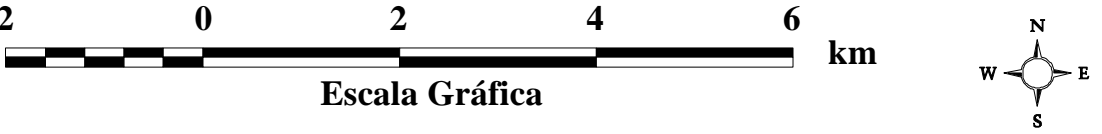

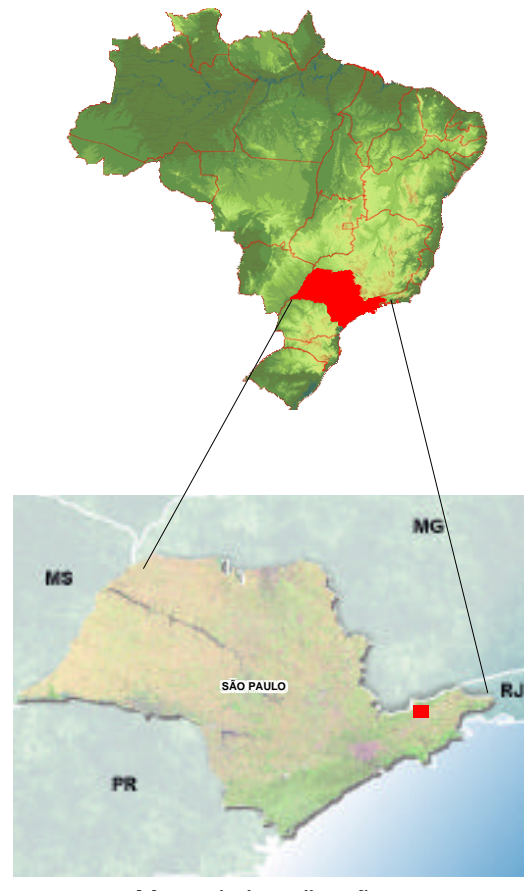

Mapa de Localização 
As altitudes variam de 550 a 1980 metros. Os mapas hipsométrico e clinográfico deixam claras as diversidades morfométricas e declividades observadas de sudeste para noroeste. É nítida a presença de uma topografia pouco dissecada e com baixas declividades no sudeste, que progressivamente, vai alterando suas feições para noroeste da área de estudo, conforme ilustra a Figura 3.7.

Esta região pode ser delimitada em três compartimentos distintos com características próprias de relevo, solo, litologia, vegetação e uso da terra. Estes compartimentos, as unidades de paisagem, podem ser subdivididos em: Bacia de Taubaté, Morros Cristalinos e Serra da Mantiqueira, como apresentado na Figura 3.6.

Pelas influências do relevo o clima desta região, segundo a classificação de Köppen, é dividido em dois subtipos: Cwa e Cwb, caracterizando-se como climas tropicais de altitude com concentração de chuvas no verão (dezembro a março) e períodos secos no inverno (junho a agosto). A precipitação média anual varia de 1100 a 1750 mm diminuindo de leste para oeste. O mês mais seco, geralmente, é julho, sendo que o total das chuvas é inferior a $15 \mathrm{~mm}$. Já o mês mais chuvoso é, em geral, janeiro, quando o total de chuvas atinge mais de dez vezes às do mês de julho. As temperaturas médias oscilam de 18 a $24 \stackrel{\circ}{ } \mathrm{C}$.

O subtipo climático Cwb diferencia-se do Cwa por apresentar maiores valores pluviométricos e menores valores térmicos, ou seja, ele é mais úmido e menos quente que o Cwa. O Cwb ocorre nas escarpas da Serra da Mantiqueira e nas partes mais elevadas das zonas das serras, já o subtipo Cwa, abrange o Vale do Paraíba e as zonas mais rebaixadas das serras, estas diferenciações pluviométricas podem ser observadas nos Gráficos 3.3 e 3.4, respectivamente. 
HIPSOMETRIA

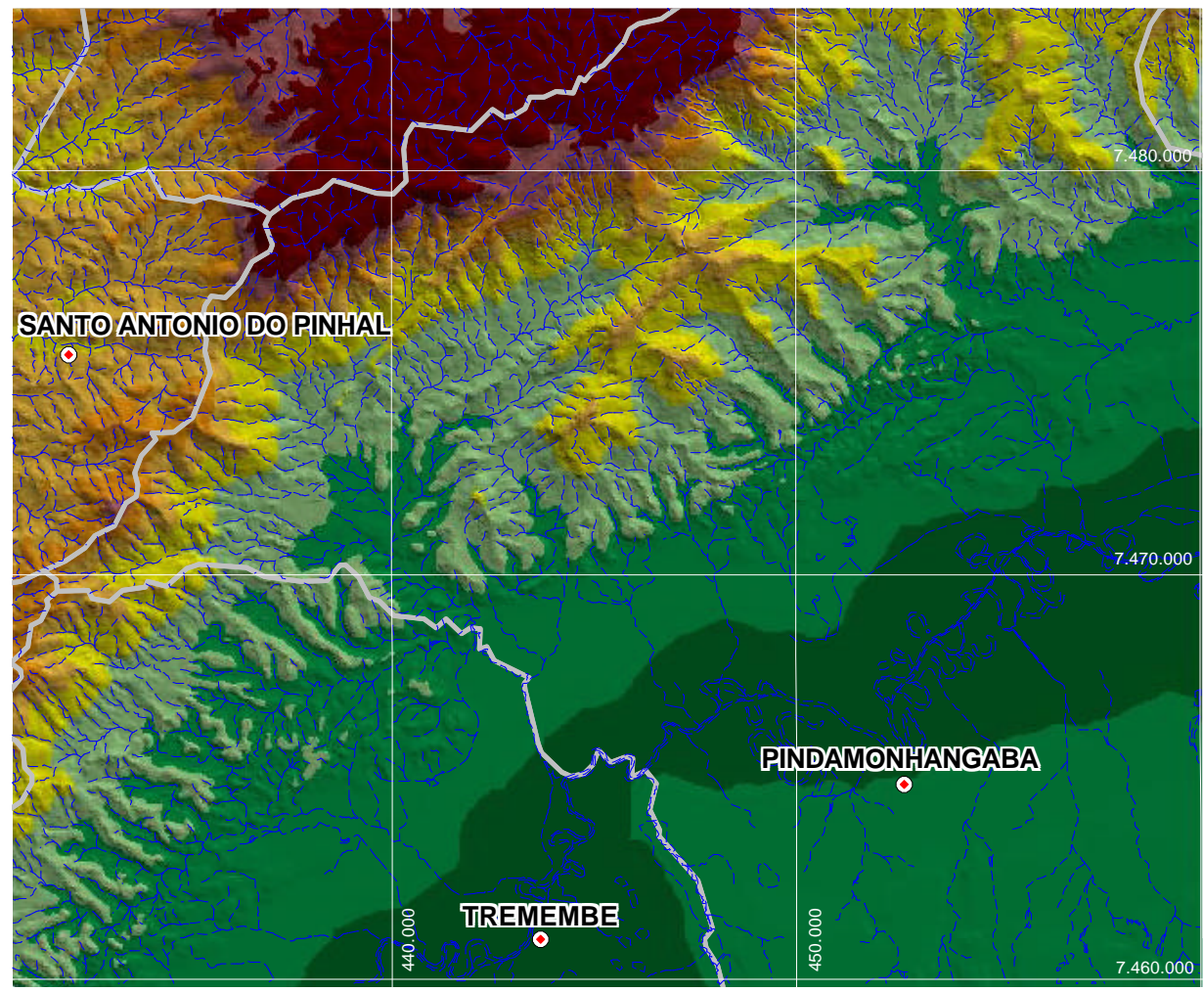

\section{Hipsometria}

< que $550 \mathrm{~m}$ De 550 a $650 \mathrm{~m}$ De 650 a $850 \mathrm{~m}$ De 850 a $1100 \mathrm{~m}$ De 1100 a $1300 \mathrm{~m}$ De 1300 a $1500 \mathrm{~m}$ De 1500 a $1700 \mathrm{~m}$ > que $1700 \mathrm{~m}$
- Sede Municipal

_ Limite Municipal

- - Hidrografia

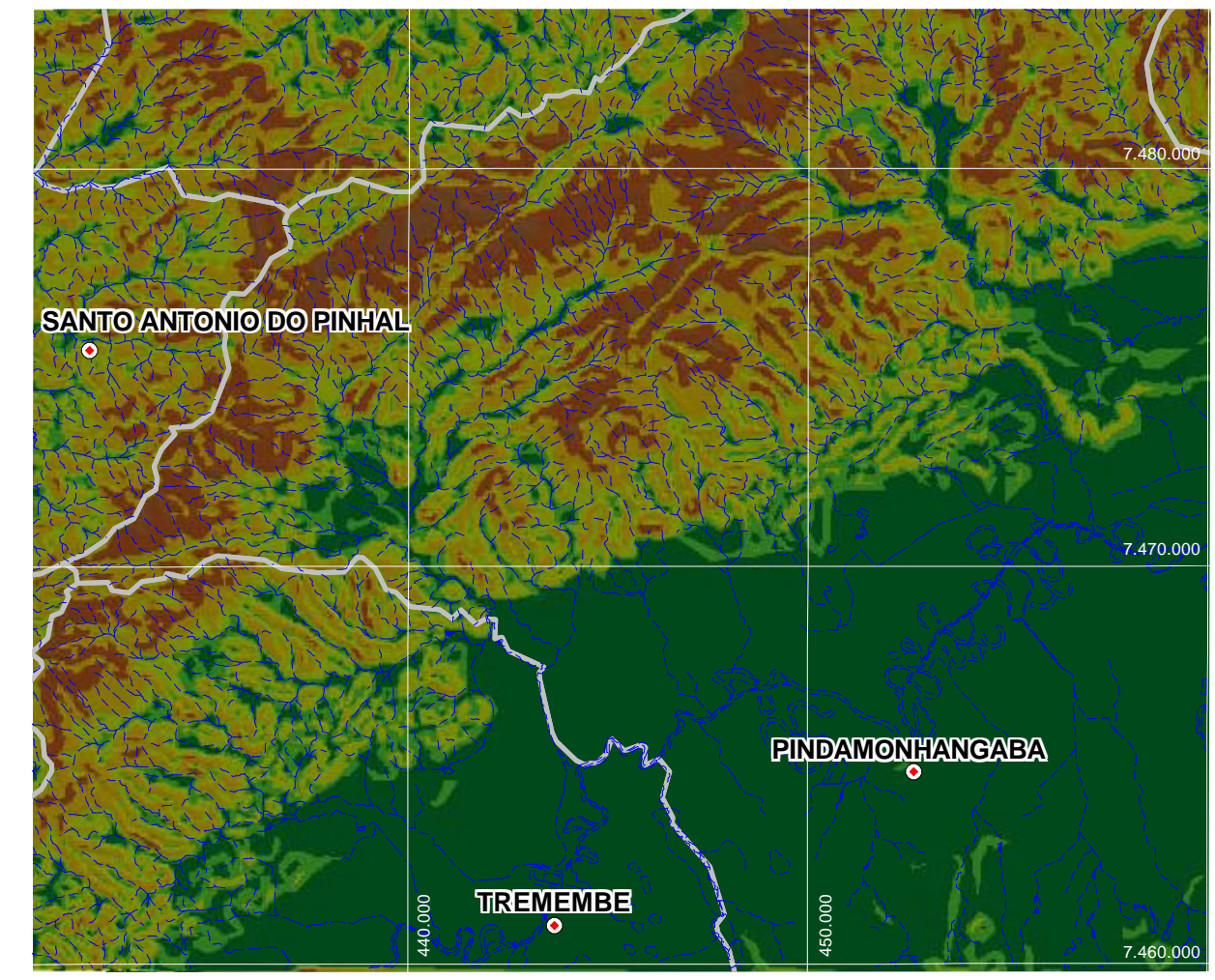

\section{Classes de Declividade}

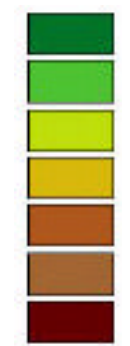
$<$ que $3 \%$
De 3 a $6 \%$
De 6 a $12 \%$
De 12 a $20 \%$
De 20 a $30 \%$
De 30 a $50 \%$
$>$ que $50 \%$

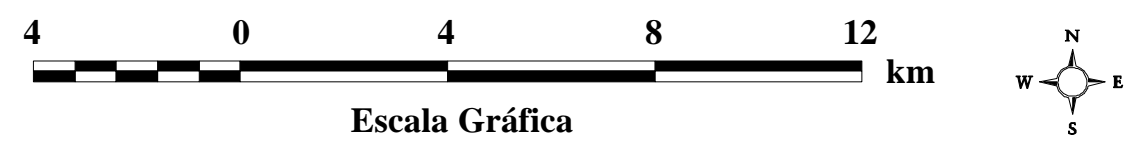

\section{DECLIVIDADES}

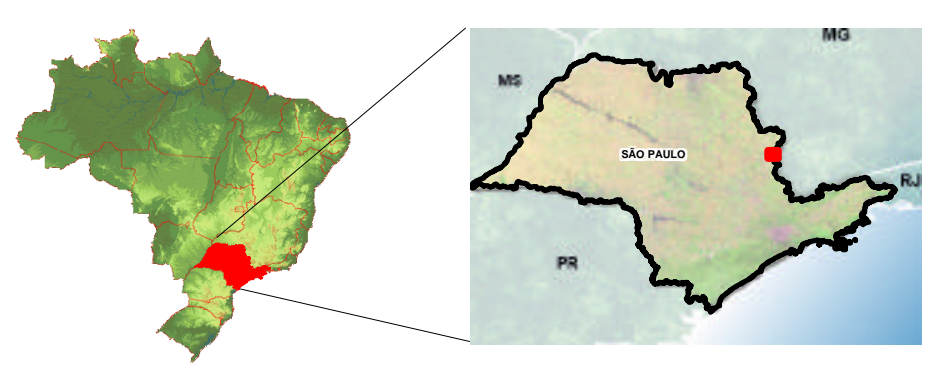

FIGURA 3.7 - HIPSOMETRIA E DECLIVIDADES DA ÁREA-TESTE 2 


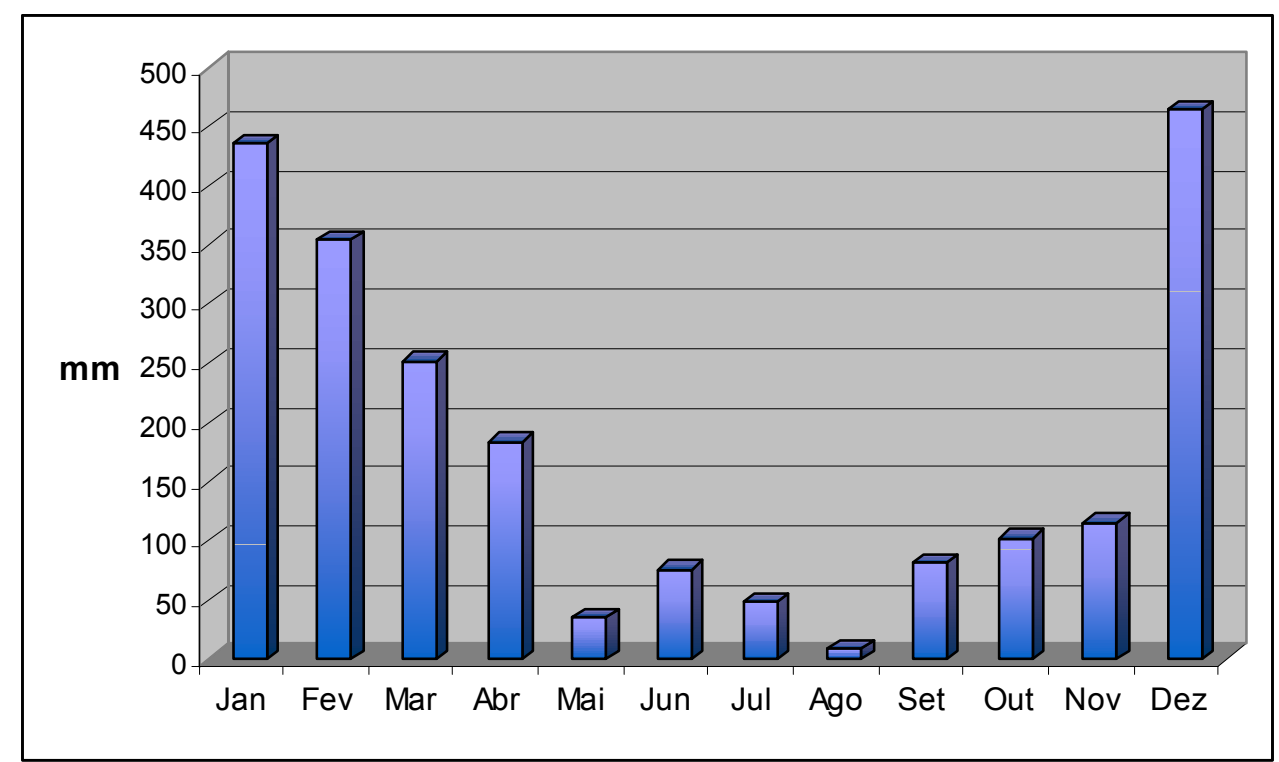

Gráfico 3.3 - Totais pluviométricos do posto D2-068, localizado em Pindamonhangaba, para o ano de 1999 - (Fonte: DAEE)

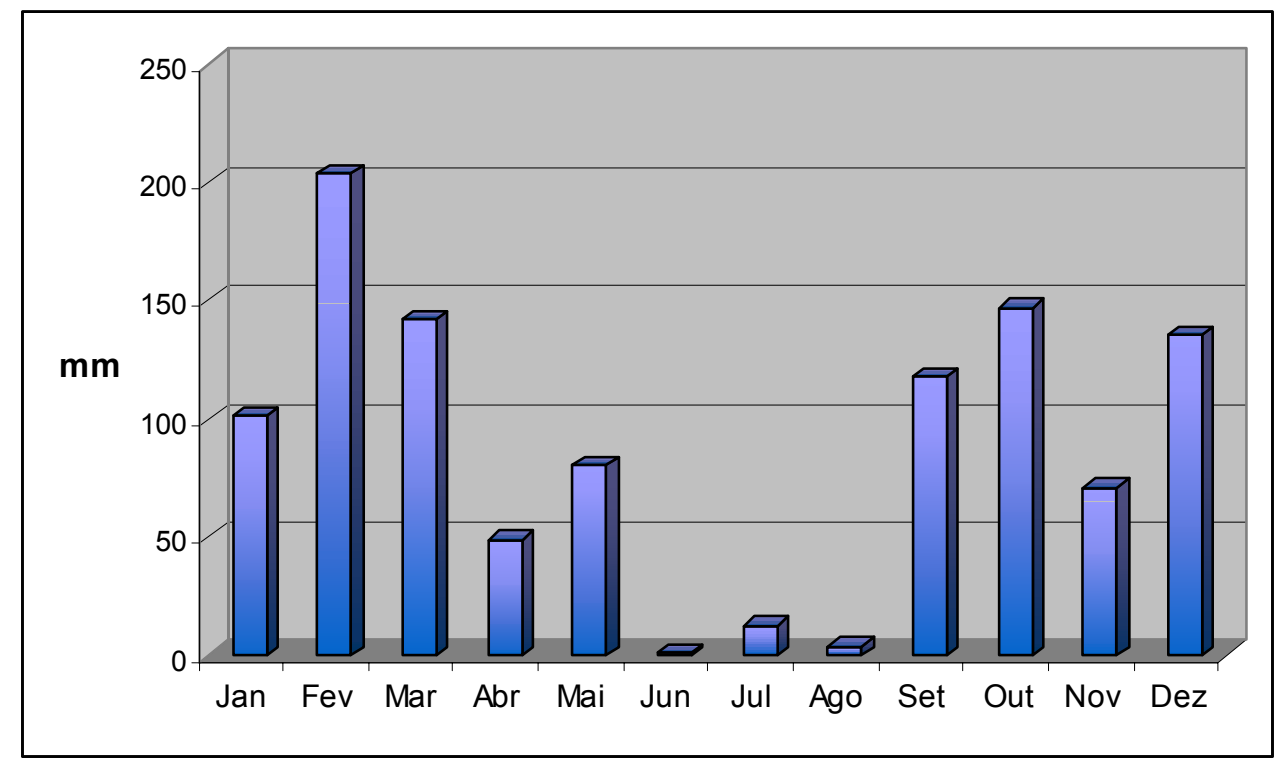

Gráfico 3.4 - Totais pluviométricos do posto D2-070, localizado em Pindamonhangaba, para o ano de 1999 - (Fonte: DAEE)

\subsection{1 - Bacia de Taubaté}

A Bacia de Taubaté abriga o leito do rio Paraíba do Sul, a faixa de meandros e os terraços fluviais que se elevam entre 3 e 8 metros acima do nível de inundação, todos sustentados pelos sedimentos aluvionares do Quaternário. Entre 550 e 600 metros verificam-se os vales abertos, e entre 600 e 650 metros estão as colinas terciárias sustentadas pelo Grupo Taubaté onde predominam formas com topos planos a convexos, declividades baixas e vertentes retilíneas. 
Neste compartimento ocorrem as rochas sedimentares do Grupo Taubaté e, os sedimentos quaternários associados ao Rio Paraíba do Sul, conforme apresentado na Figura 3.8.

O Grupo Taubaté é designado para representar o pacote sedimentar que se instalou no "graben" formado a partir do contato das falhas conjugadas nas bordas NO e SE e que provocou o basculamento de blocos com ampla subsidência da bacia e soerguimento das serras do Mar e da Mantiqueira. Esse grupo acha-se constituído da Formação Tremembé.

Os depósitos aluvionares ocorrem associados ao rio Paraíba do Sul e seus tributários. Esses depósitos são arenosos e silto-argilosos, verificando-se ainda a presença de turfeiras na planície e coluviões.

Os solos predominantes nesta área são os Latossolos Vermelho-Amarelos e os Gleissolos Melânicos associados às planícies fluviais do Rio Paraíba do Sul.

Os Latossolos Vermelho-Amarelos são, em geral, solos com boas propriedades físicas. Apresentam teores de $\mathrm{Fe}_{2} \mathrm{O}_{3}$ iguais ou inferiores a $11 \%$. São profundos ou muito profundos, bem drenados, com textura argilosa, muito argilosa ou média. Suas principais limitações são a acidez elevada e a fertilidade química baixa. Requerem um manejo adequado com correção da acidez, adubação fertilizante e controle de erosão. Estas características impõem algumas dificuldades à utilização intensiva destes solos pela agricultura, destinados portanto, principalmente às pastagens, conforme observado na Figura 3.9.

Os Gleissolos Melânicos são hidromórficos, situados nas planícies aluviais e muito mal drenados. Apresentam sérias limitações impostas pela presença de lençol freático a pouca profundidade. Por estarem situados nas várzeas do Paraíba do Sul, oferecem limitações quanto ao risco de inundações.

A maioria dos Gleissolos é distrófico e bastante ácido, requerendo a aplicação de corretivos e fertilizantes para a obtenção de colheitas satisfatórias. Estas áreas de planícies fluviais do Rio Paraíba do Sul, onde predominam os Gleissolos Melânicos, são amplamente utilizadas para o cultivo de arroz irrigado, também se destacando a extração de areia, conforme apresentado na Foto 3.5. 


\section{SOLOS}

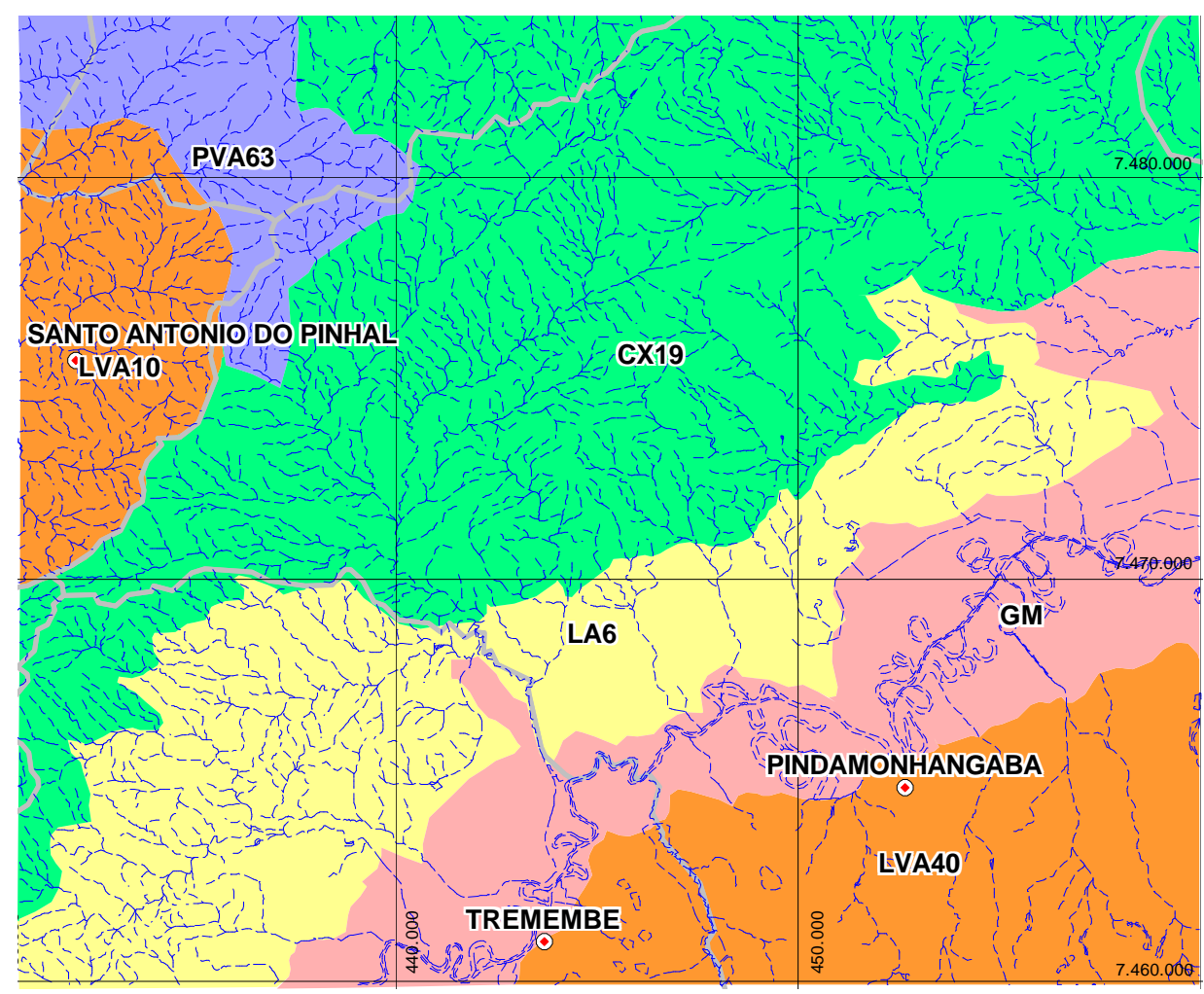

\section{SOLOS}

Argissolos Vermelho-Amarelos

Cambissolos

Gleissolos Melânicos

Latossolos Amarelos

- Latossolos Vermelho-Amarelos

- Sede Municipal

- Limite Municipal

— Limite Estadual

-. Hidrografia

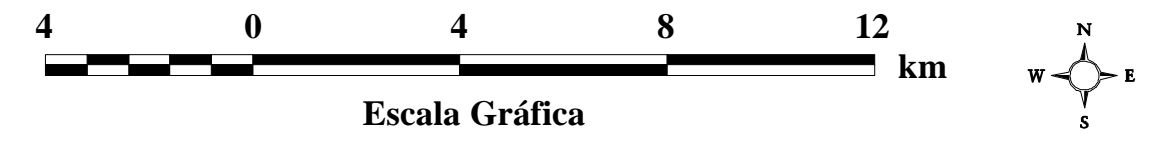

GEOLOGIA

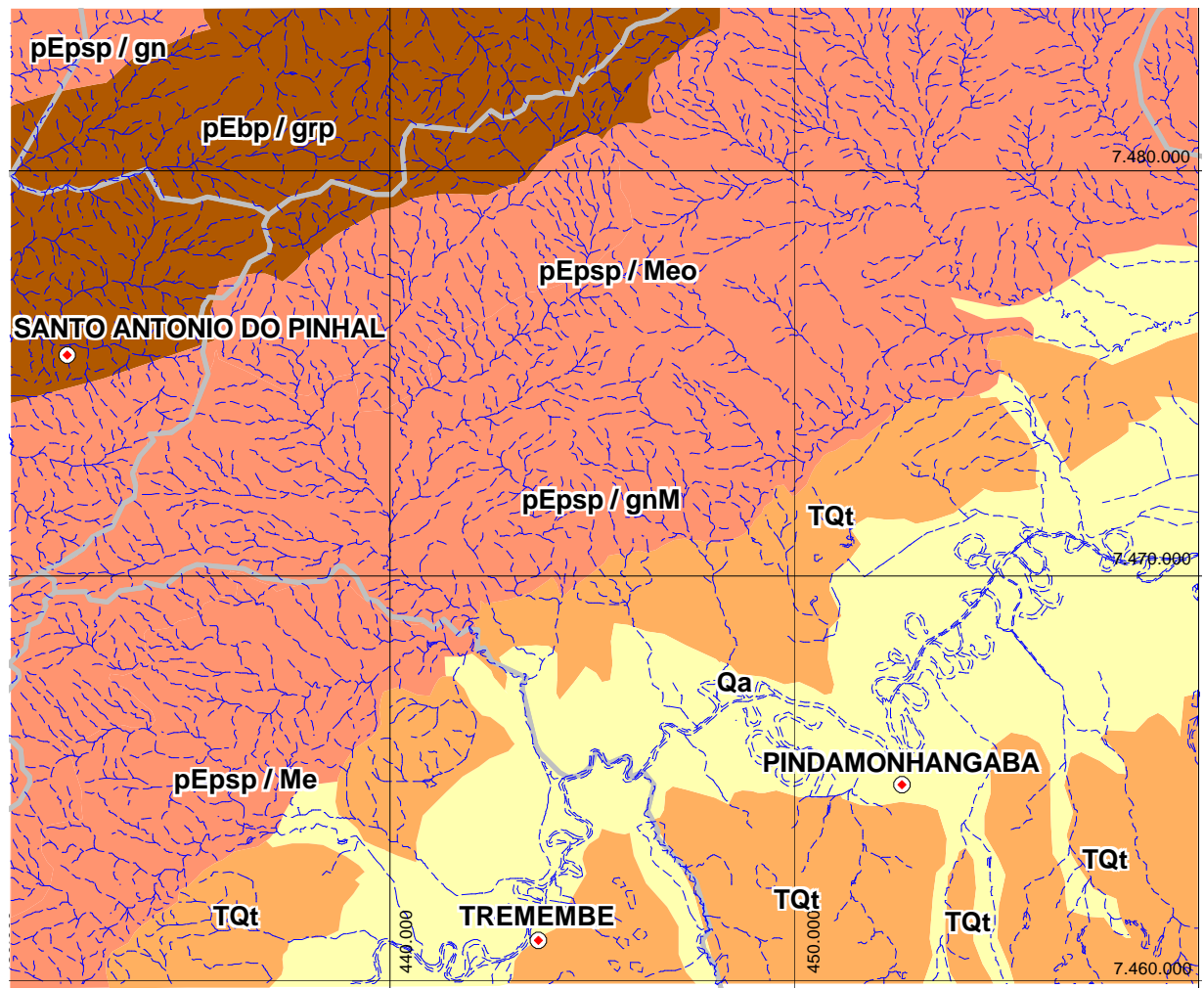

\section{GEOLOGIA}

Complexo Paraisópolis

Complexo Piquet Depósitos Aluviais

Grupo Taubaté

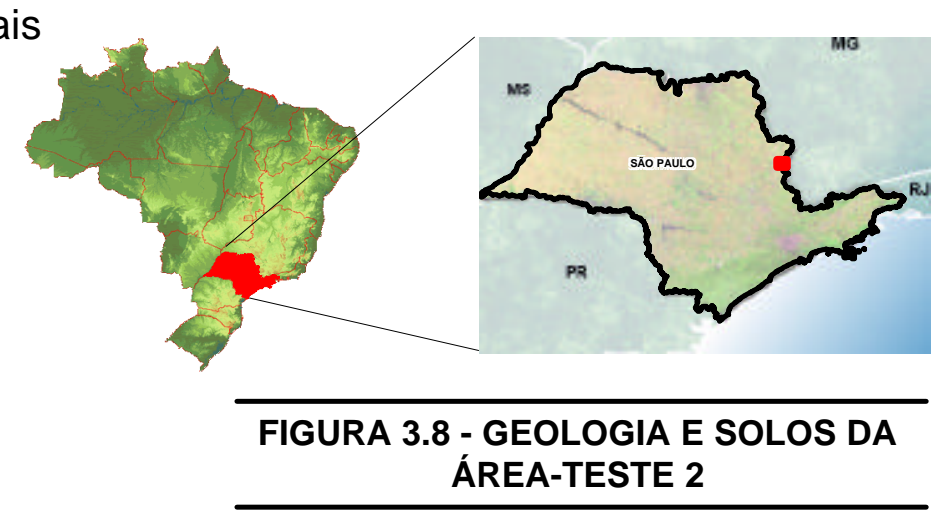




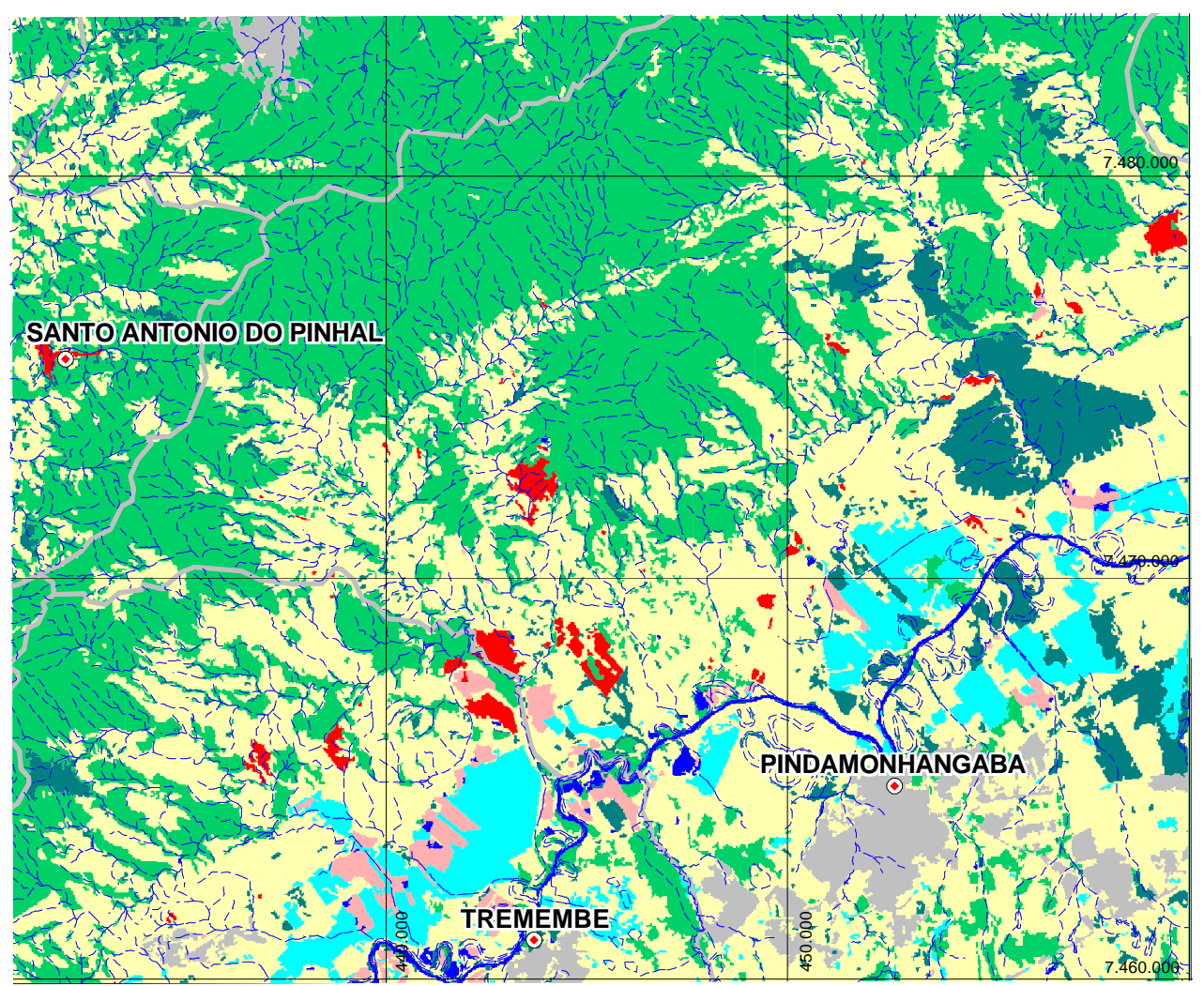

\section{USO E OCUPAÇÃO}

Agricultura Ciclo Curto

Área Urbana

Arroz Irrigado

Corpos d'água

Mata

Pastagem

Porto de Areia

Reflorestamento
_Limite Municipal

_ Limite Estadual

- - Hidrografia

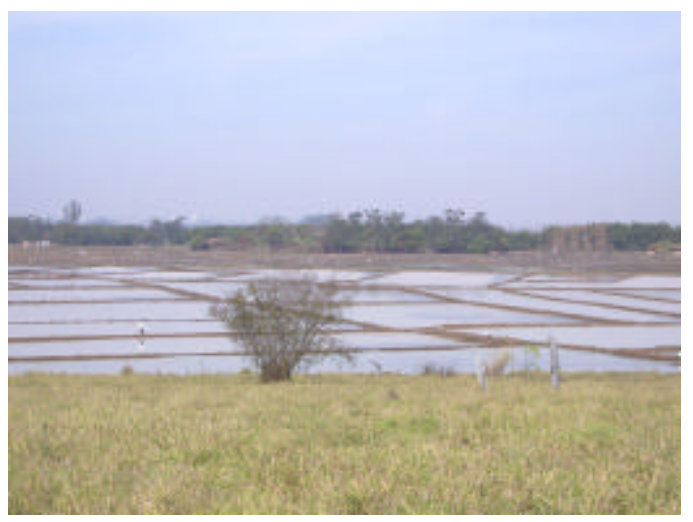

Foto 3.5 - Arroz irrigado nas planícies do Rio Paraíba do Sul

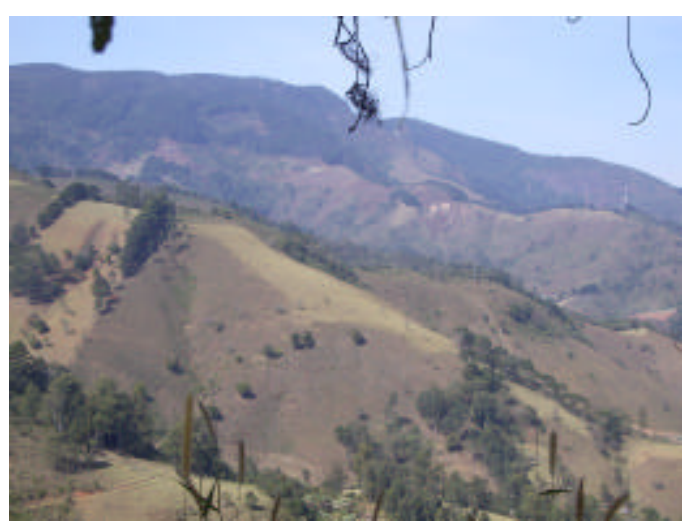

Foto 3.7 - Relevo dissecado da Serra da Mantiqueira

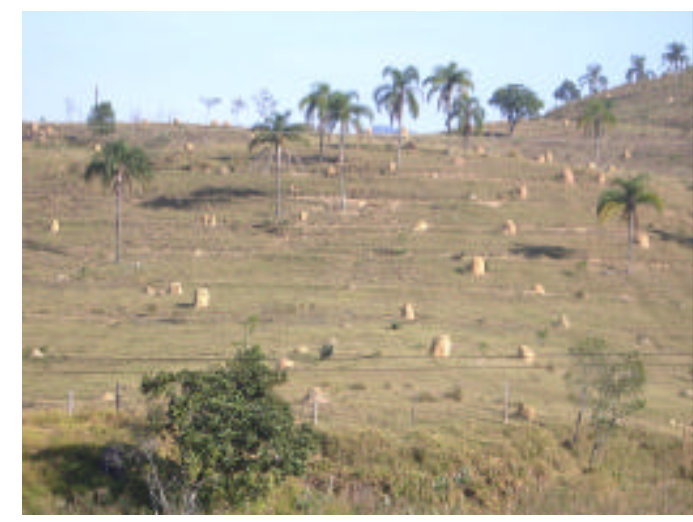

Foto 3.6 - Áreas de Latossolo Amarelo destinadas à pastagem

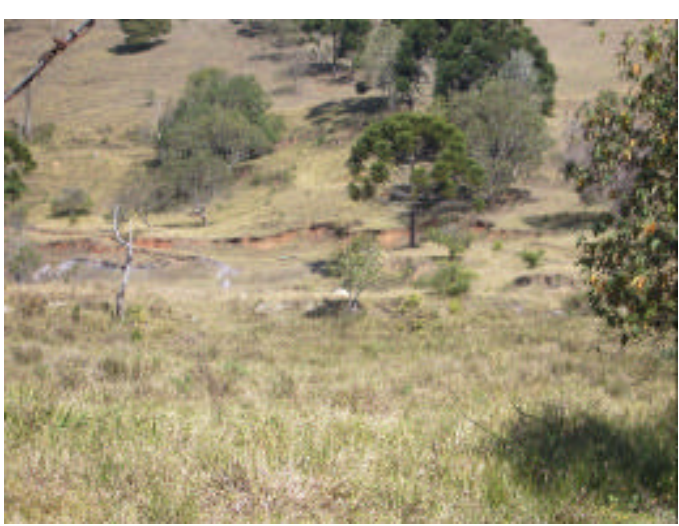

Foto 3.8 - Vegetação de campo de altitude na Serra da Mantiqueira
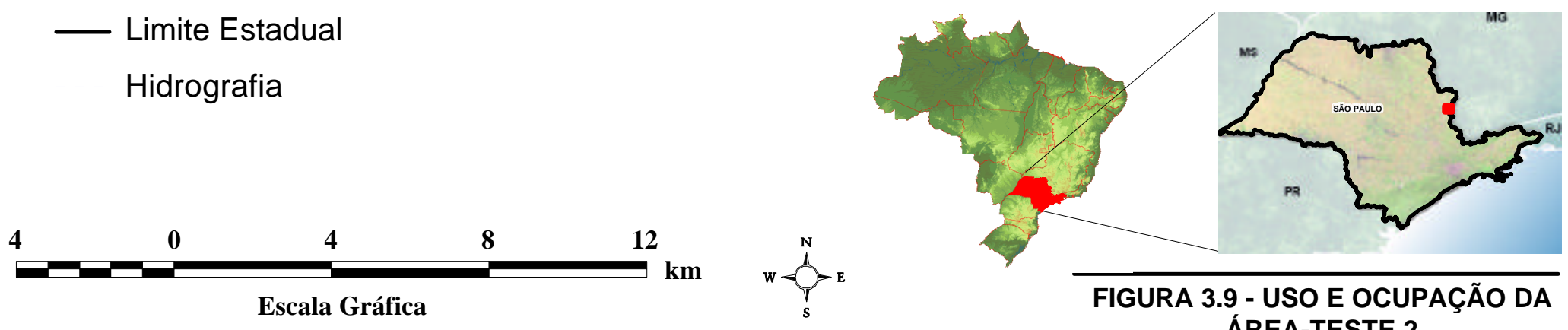

FIGURA 3.9 - USO E OCUPAÇÃO DA ÁREA-TESTE 2 


\subsection{2 - Morros Cristalinos}

A sub-zona dos Morros Cristalinos representa um relevo de transição para o Planalto do Paraitinga ao sul e a Serra da Mantiqueira ao norte. As elevações variam entre 700 e 1000 metros. As formas de relevo aí presentes emolduram a Bacia de Taubaté e são representadas por morros e morrotes com topos angulares a arredondados e vertentes tendendo à convexidade.

Neste compartimento ocorrem as rochas atribuídas a Associação Paraíba do Sul (Complexo Piquete). O Complexo Piquete trata-se de maciços rochosos que apresentam ocorrências regulares ou irregulares de massas quartzo-feldspáticas, dispostas em concordância ou não com a foliação ou xistosidade da rocha predominante, sob as mais variadas formas.

Os solos predominantes desta área são os Latossolos Amarelos que apresentam baixos teores de $\mathrm{Fe}_{2} \mathrm{O}_{3}$, em sua maioria, abaixo de $7 \%$. São solos bem drenados, profundos e muito profundos, com predominância de textura média, baixa relação textural e pouca diferenciação entre os horizontes. Suas principais limitações decorrem da forte acidez, alta saturação com alumínio extraível e baixa fertilidade química natural. São, portanto, solos muito pobres em nutrientes, utilizados principalmente para pastagens, conforme apresentado na Figura 3.9.

\subsection{3 - Serra da Mantiqueira}

A zona geomorfológica da Serra da Mantiqueira ocupa a porção noroeste da área-teste 2, acima da zona de falha do Rio Jaguari. Esse setor caracteriza-se por elevações entre 800 e 1980 metros, escarpas vigorosas, declives acentuados entre 12 e 30\%, conforme apresentado na Foto 3.7.

Nas íngremes vertentes da Mantiqueira aparecem manchas da floresta perenifólia costeira decorrente das condições de relevo, pluviosidade e umidade. Tal floresta é densa, os estratos inferiores vivem em ambientes sombrios e úmidos, numa contínua dependência do superior, é a típica floresta tropical. Os elementos mais altos podem alcançar de 25 a $30 \mathrm{~m}$.

Nas altitudes acima de $1000 \mathrm{~m}$ aparecem campos, caracterizados por uma cobertura herbácea, muitas vezes contínua, em meio à qual podem aparecer arbustos isolados, ou em tufos, conforme apresentado na Foto 3.8. Esta vegetação ocorre em áreas de elevada altitude aliada a topografia suave, solos rasos, drenagem insipiente e clima ameno.

Neste compartimento ocorrem as rochas atribuídas ao Complexo Paraisópolis (PréCambriano), onde se destacam os migmatitos, nebulíticos, granitóides, porfiroblásticos e granulíticos, granulitos, granitos e granodioritos gnáissicos. 
Os solos predominantes desta unidade de paisagem são os Argissolos VermelhoAmarelos, os Cambissolos Háplicos e, em menor proporção os Latossolos VermelhoAmarelos.

Os Argissolos Vermelho-Amarelos estão situados em áreas de relevo predominantemente ondulado e montanhoso, localizados a noroeste desta região.

Os Cambissolos Háplicos ocorrem em regiões serranas em relevo montanhoso e escarpado. De modo geral, não são utilizados agricolamente por apresentarem como fator limitante ora o relevo acentuado ora o excesso de alumínio. É, portanto, recomendado como uso mais adequado à pecuária extensiva e a silvicultura.

Os Latossolos Vermelho-Amarelos são, em geral, solos com boas propriedades físicas. Apresentam teores de $\mathrm{Fe}_{2} \mathrm{O}_{3}$ iguais ou inferiores a $11 \%$. São profundos ou muito profundos, bem drenados, com textura argilosa, muito argilosa ou média. Suas principais limitações são a acidez elevada e a fertilidade química baixa. Requerem um manejo adequado com correção da acidez, adubação fertilizante e controle de erosão. 


\section{4 - PROCEDIMENTOS TÉCNICO-OPERACIONAIS}

Após a definição do tema, da linha de pesquisa e da abordagem metodológica, foi desenvolvida uma seqüência de atividades operacionais para a execução do estudo.

Os passos adotados no desenvolvimento desta pesquisa estão representados graficamente através do fluxograma apresentado a seguir, no qual se buscou proceder à caracterização e análise da paisagem de maneira integrada nas áreas-teste.

Este fluxograma auxilia na condução dos trabalhos, mostrando de forma sistematizada a seqüência das diferentes etapas desenvolvidas nesta pesquisa, imprimindo uma ordem lógica, seguindo o roteiro metodológico proposto por Libault (1971), que subdivide a pesquisa geográfica em quatro níveis, conforme apresentado na Figura 4.1. 


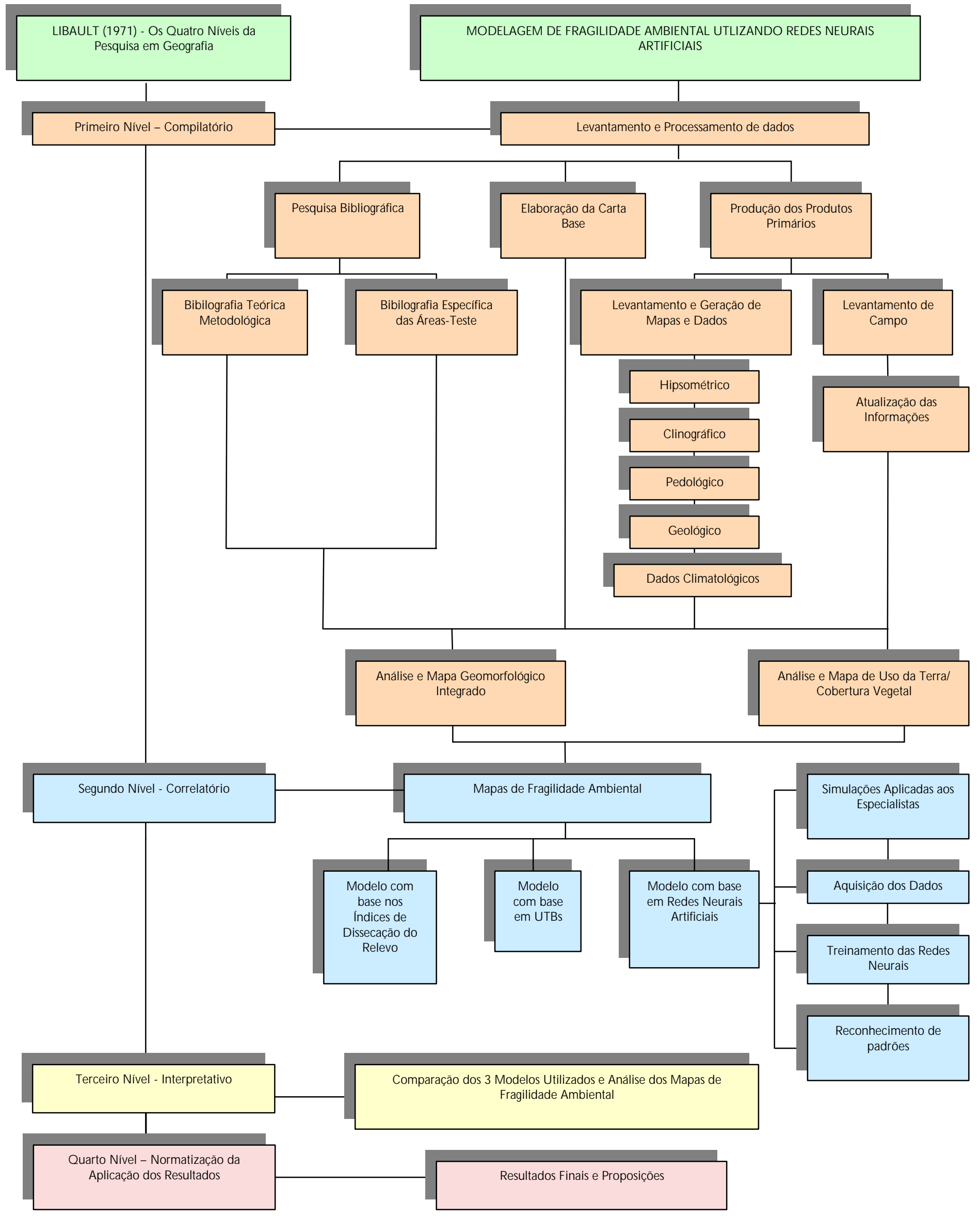

Figura 4.1 - Fluxograma 


\section{1 - Primeiro Nível: Compilatório}

Neste primeiro nível foram realizadas pesquisas bibliográficas, levantamentos de dados e informações sobre a existência de cartas topográficas, geológicas, geomorfológicas, pedológicas e documentos básicos produzidos por sensores remotos (fotografias aéreas e imagens de satélite).

Após o reconhecimento do material disponível foram elaborados vários documentos, assim como, as cartas hipsométrica, clinográfica, geológica, pedológica, uso da terra/cobertura vegetal e compilação de dados climatológicos. Estes documentos gerados encontram-se detalhados no Capítulo 5.

\section{2 - SeGundo Nível: Correlatório}

Nesta fase da pesquisa foram correlacionadas as informações analíticas da fragilidade do meio físico, englobando clima, relevo, litologia, solos, uso da terra/cobertura vegetal. Através da correlação desses mapeamentos intermediários foram elaboradas as cartas sínteses de Fragilidade Ambiental aplicando-se as propostas metodológicas de Ross (1994) e Crepani et al. (2001) nas duas áreas-teste. Estas duas metodologias e os mapeamentos sínteses resultantes encontram-se detalhados no Capítulo 6.

Também é apresentada nesta etapa uma nova proposta metodológica para elaboração de modelos de fragilidade ambiental utilizando redes neurais artificiais. Esta metodologia apresenta-se detalhada no Capítulo 7.

\section{3 - TERCEIRO NÍVEL: SEMÂNTICO (INTERPRETATIVO)}

Nesta fase da pesquisa são interpretadas as informações obtidas buscando-se atingir os objetivos propostos. Este nível de abordagem contempla duas etapas:

- a análise dos resultados das simulações e do treinamento das redes neurais dos especialistas consultados, visando checar o desempenho e a confiabilidade das RNAs no reconhecimento dos padrões de avaliação destes especialistas. Estes resultados estão apresentados no Capítulo 8;

- e a comparação dos modelos existentes Ross (1994), Crepani et al. (2001) e os modelos resultantes das respectivas RNAs destes especialistas, confrontando-se os mapeamentos sínteses resultantes da aplicação destes modelos. Os resultados destes modelos metodológicos são analisados e comparados em dois contextos diferenciados, ou seja, em duas áreas com características físicas e bióticas bastante divergentes, possibilitando a checagem das metodologias em diferentes cenários. Esta análise comparativa entre os modelos apresenta-se detalhada no Capítulo 9.

Este nível da pesquisa contempla a análise e a síntese e permite chegar aos resultados. 


\section{4 - QuARTO Nível: NORMATIVO}

O quarto nível desta pesquisa envolve a normatização da aplicação dos resultados. Para finalizar, no Capítulo 10, são apresentadas então as considerações finais desta pesquisa, formulando uma síntese do trabalho e, onde são apresentados os resultados finais e as proposições. 


\section{5 - MATERIAIS E MÉTODOS}

Neste capítulo são apresentados os materiais utilizados e os produtos gerados para o desenvolvimento desta pesquisa. Após a seleção das áreas-teste procedeu-se a coleta dos dados referentes às cartas topográficas, mapas temáticos e imagens de satélite destas áreas.

\section{1 - Produtos CaRtográficos e ImaGens Utilizados}

Neste trabalho foram utilizados os documentos cartográficos e imagens listados no Quadro 5.1.

Quadro 5.1 - Documentos cartográficos e imagens

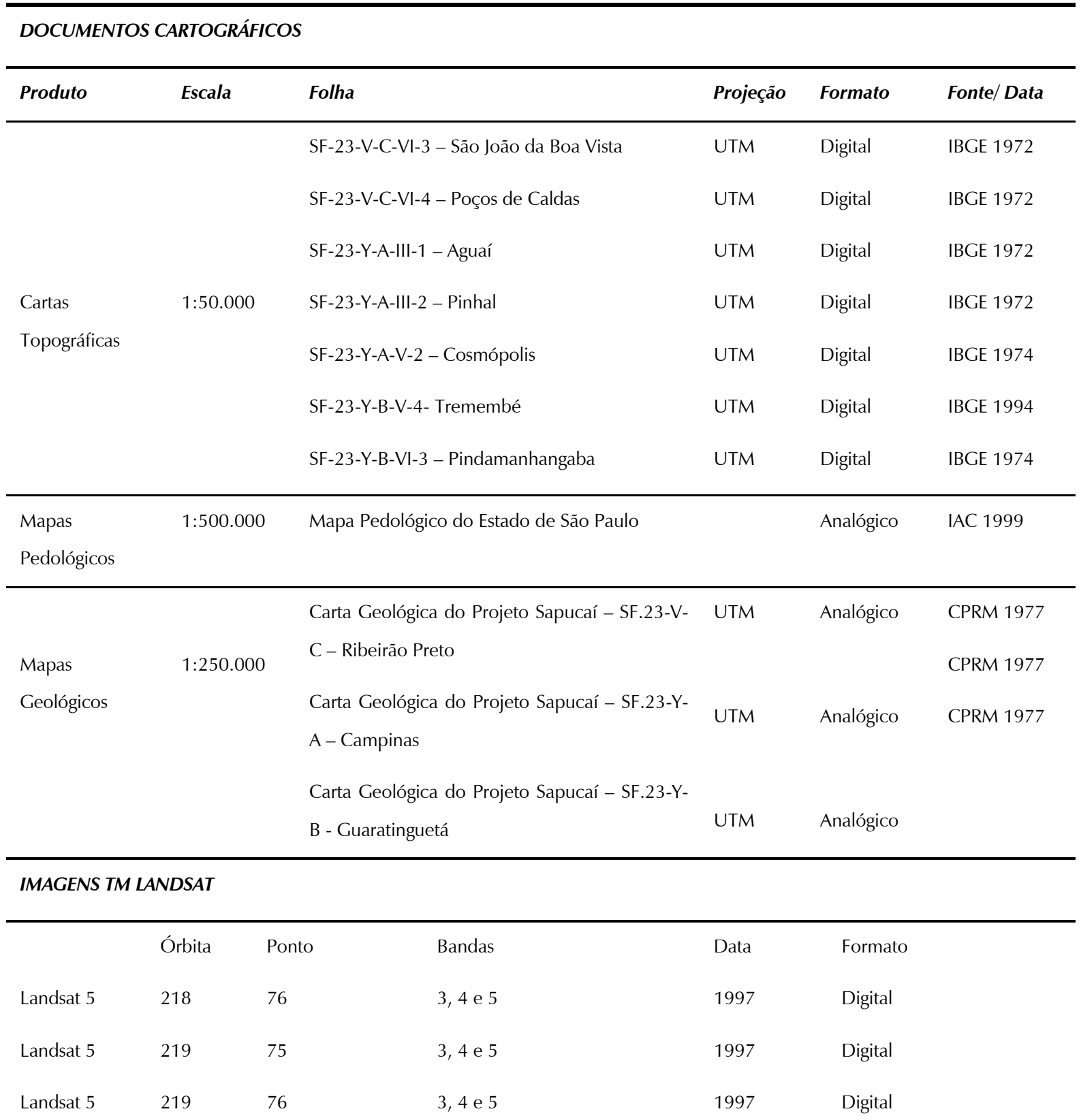




\section{1 - Descrição dos Produtos Gráficos e Cartográficos primários GERADOS}

Após o reconhecimento do material disponível foram elaborados vários documentos primários que subsidiaram os mapeamentos de fragilidade ambiental, tais como, os mapas hipsométrico, clinográfico, geológico, pedológico e dados climatológicos. A seguir são apresentadas as descrições de cada um destes produtos.

\subsection{1 - Carta Hipsométrica}

Para a construção de cartas hipsométricas não há uma convenção internacional para o estabelecimento das curvas a serem agrupadas. Na determinação do intervalo das isoípsas é mais importante uma análise da topografia da área a ser mapeada do que seguir regras gerais existentes.

Sendo assim, levou-se em consideração a topografia das duas áreas-teste avaliadas neste estudo. A amplitude altimétrica dessas áreas é significativa conforme apresentado a seguir:

- Área-Teste 1: de 680 a 1620 metros

- Área-Teste 2: de 540 a 1980 metros

Desta forma, para a hipsometria das áreas-teste foram adotadas as seguintes classes altimétricas:

- < que 550 metros

- De 550 a 650 metros

- De 650 a 850 metros

- De 850 a 1100 metros

- De 1100 a 1300 metros

- De 1300 a 1500 metros

- De 1500 a 1700 metros

- > que 1700 metros

\subsection{2 - Carta Clinográfica}

A elaboração da carta clinográfica tem como objetivo identificar e correlacionar as declividades com as formas de relevo e com o uso da terra. A classificação e o mapeamento da declividade do terreno são indispensáveis nos levantamentos de uso da terra e do relevo, e constituem elementos importantes no levantamento de sua 
potencialidade de utilização. Sendo assim, a declividade deve ser considerada como uma variável reveladora de aptidões e limitações de uso da terra.

Este mapa de declividade foi produzido a partir do modelo numérico do terreno (MNT), o qual foi obtido pela interpolação dos pontos cotados existentes ao longo das curvas de nível do mapa base topográfico, através do modelo TIN (Triangular Irregular Network). O modelo numérico obtido após a triangulação foi reclassificado, de forma a gerar sete classes de declividade, conforme apresentado a seguir:

- $<$ que $3 \%$

- De 3 a $6 \%$

- De 6 a $12 \%$

- De 12 a $20 \%$

- De 20 a $30 \%$

- De 30 a $50 \%$

- $>$ que $50 \%$

Estas classes seguiram os intervalos descritos por Ross (1994), as quais são usadas internacionalmente nos mapeamentos dos tipos de solos, normatizados e aplicados no Brasil pela EMBRAPA, IBGE, RADAMBRASIL e outros. Estas classes foram adotadas por serem compatíveis para análise dinâmica do relevo e, também, por possibilitarem a identificação das áreas de maior ou menor risco de erosão, de acordo com a característica de fragilidade potencial que são inerentes a cada classe de declividade.

\subsection{3 - Mapa Geológico}

A geologia contribui para a análise e definição da categoria morfodinâmica da paisagem compreendendo as informações relativas ao grau de coesão dos minerais que compõem as rochas e as informações relativas à evolução do seu ambiente geológico.

Devido à carência de mapas detalhados de geologia para as áreas-teste foram consideradas para a caracterização desse item informações provenientes das Cartas Geológicas do Projeto Sapucaí, na escala 1:250.000, produzidas pelo Departamento Nacional da Produção Mineral - DNPM, 1979.

Com o objetivo de aumentar a consistência entre os mapas utilizados e ajustar a escala de origem para a escala de trabalho foi efetuada a reinterpretação destas cartas geológicas usando como "âncora" as imagens de satélite TM/Landsat.

Estas informações serviram de base para a confecção dos mapas geológicos apresentando os principais tipos de rocha existentes nas áreas-teste, os quais estão apresentados no Quadro 5.2. 
Quadro 5.2 - Rochas ocorrentes nas áreas-teste

\begin{tabular}{|c|c|c|}
\hline $\begin{array}{l}\text { Área- } \\
\text { Teste }\end{array}$ & Estratigrafia & Litologia \\
\hline 1 & $\begin{array}{l}\text { Maciço Alcalino de Poços de Caldas (Kfn) } \\
\text { Complexo Socorro (grs e ar) } \\
\text { Complexo Varginha (PEbv/Mgr) } \\
\text { Depósitos Aluviais (Qa) }\end{array}$ & $\begin{array}{l}\text { fonolitos, foiaítos e tinguaítos } \\
\text { arenitos indiferenciados } \\
\text { migmatitos granitóides } \\
\text { depósitos sedimentares aluviais }\end{array}$ \\
\hline 2 & $\begin{array}{l}\text { Grupo Taubaté (TQt) } \\
\text { Complexo Piquete (pEsp/gn e gnM) } \\
\text { Complexo Piquete (pEpsp/Me e Meo) } \\
\text { Complexo Paraisópolis (pEpsp/gnM) } \\
\text { Depósitos Aluviais (Qa) }\end{array}$ & $\begin{array}{l}\text { folhelhos pirobetuminosos } \\
\text { biotita-gnaisses } \\
\text { migmatitos estromáticos } \\
\text { granitos e granitóides porfiroblásticos } \\
\text { depósitos sedimentares aluviais }\end{array}$ \\
\hline
\end{tabular}

\subsection{4 - Mapa Pedológico}

A resistência dos solos aos processos erosivos é conseqüência do tipo de solo, e também, das suas características físicas, tais como, textura, estrutura, porosidade, permeabilidade, profundidade e pedregosidade. As características do solo é que definem sua maior ou menor susceptibilidade aos processos erosivos, daí a importância desta variável para estabelecer a fragilidade do ambiente.

Devido à falta de mapas detalhados de solos das áreas-teste foram considerados para a caracterização desse item dados provenientes do Mapa Pedológico do Estado de São Paulo, na escala 1:500.000, realizado pelo Instituto Agronômico de Campinas - IAC, 1999.

Com o objetivo de aumentar a consistência entre os mapas utilizados e ajustar a escala de origem para a escala de trabalho, foi efetuada a reinterpretação dos mapas preexistentes usando como "âncora" as imagens de satélite TM/Landsat.

Os limites de cada unidade foram traçados com auxílio de imagens TM/Landsat e com informações obtidas através do Mapa Pedológico do Estado de São Paulo (IAC, 1999), levando-se em consideração principalmente a intensidade de dissecação do relevo e o padrão de drenagem. As unidades pedológicas normalmente seguem as formas e a intensidade de dissecação do relevo. Portanto, a partir da delimitação das unidades geomorfológicas, tornou-se possível inferir o limite das unidades de solos.

Estas informações serviram de base para a confecção do mapa contendo os principais tipos de solos presentes nas áreas-teste. Os solos ocorrentes nas áreas-teste estão apresentados no Quadro 5.3. 
Quadro 5.3 - Solos ocorrentes nas áreas-teste

\begin{tabular}{clc}
\hline $\begin{array}{c}\text { Área- } \\
\text { Teste }\end{array}$ & Tipo de Solo & Sigla \\
\hline \multirow{3}{*}{1} & Cambissolos Háplicos & CX13 \\
& Neossolos Litólicos & $\mathrm{R}$ \\
& Nitossolos & TBe \\
& Argissolos Vermelho-Amarelos & PVA8 \\
\hline & Cambissolos Háplicos & CX19 \\
& Gleissolos Melânicos & GM \\
& Latossolos Amarelos & LA6 \\
& Latossolos Vermelho-Amarelos & LVA10, LVA40 \\
& Argissolos Vermelho Amarelos & PVA63 \\
\hline
\end{tabular}

\subsection{5 - Dados Climáticos}

As informações climatológicas, principalmente as chuvas, são de fundamental importância para a análise da fragilidade em função da sua ação direta na dinâmica do sistema ambiental. A ação das chuvas, principalmente quando concentradas em pequenos períodos, é um importante elemento modificador por regular e ativar todos os processos morfodinâmicos contribuindo diretamente para acelerar os processos erosivos.

As principais características físicas, da chuva, envolvidas nos processos erosivos são: a pluviosidade total, a intensidade pluviométrica e a distribuição sazonal. Dentre as três características a mais importante é a intensidade pluviométrica, pois representa uma relação entre as outras duas características (quanto chove/quando chove), resultando na quantidade de energia potencial disponível para transformar-se em energia cinética. Isto quer dizer que quanto maiores os valores da intensidade pluviométrica maior será a erosividade da chuva.

O valor da intensidade pluviométrica pode ser obtido dividindo-se o valor da pluviosidade média anual (em mm) pela duração do período chuvoso (em meses).

A distribuição e a intensidade das chuvas ao longo do ano são fatores decisivos no processo de intemperismo de rochas e solos, ou seja, são fundamentais para a análise da fragilidade ambiental.

Desta forma, estes dados climáticos subsidiam os conhecimentos sobre os solos, a dinâmica do relevo, assim como, dão suporte ao entendimento da distribuição da cobertura vegetal e, ao comportamento do regime hídrico dos rios.

Para subsidiar esta análise sobre as características das chuvas foram avaliados os postos pluviométricos distribuídos pelas duas áreas-teste, os quais dispunham de dados no período entre 1975 e 1995. Estes dados de precipitação, obtidos junto ao DAEE, foram transformados em intensidade pluviométrica. O Quadro 5.4 apresenta as características e informações destes postos e a Figuras 5.1 a distribuição espacial dos mesmos: 
Quadro 5.4 - Dados dos postos pluviométricos

\begin{tabular}{|c|c|c|c|c|c|}
\hline $\begin{array}{l}\text { Área- } \\
\text { Teste }\end{array}$ & $\begin{array}{c}\text { Postos } \\
\text { Pluviométricos }\end{array}$ & $\begin{array}{l}\text { Altitude } \\
\text { (m) }\end{array}$ & $\begin{array}{l}\text { Pluviosidade } \\
\text { Média }(\mathrm{mm}) \\
\text { (1975-1995) }\end{array}$ & $\begin{array}{c}\text { Duração do } \\
\text { Período Chuvoso } \\
\text { (meses) }\end{array}$ & $\begin{array}{c}\text { Intensidade } \\
\text { Pluviométrica } \\
\text { (mm/mês) }\end{array}$ \\
\hline 1 & $\begin{array}{l}\text { D3-031 } \\
\text { D3-034 } \\
\text { D3-043 }\end{array}$ & $\begin{array}{c}740 \\
940 \\
1310\end{array}$ & $\begin{array}{l}1461,2 \\
1680,1 \\
1892,8\end{array}$ & $\begin{array}{l}8 \\
8 \\
8\end{array}$ & $\begin{array}{l}182,65 \\
210,01 \\
236,60\end{array}$ \\
\hline 2 & $\begin{array}{l}\text { D2-004 } \\
\text { D2-014 } \\
\text { D2-041 } \\
\text { D2-067 } \\
\text { D2-068 } \\
\text { D2-070 } \\
\text { D2-071 } \\
\text { D2-075 }\end{array}$ & $\begin{array}{c}1220 \\
528 \\
540 \\
640 \\
1840 \\
530 \\
610 \\
700\end{array}$ & $\begin{array}{l}1715,3 \\
1344,8 \\
1317,1 \\
1441,8 \\
1731,8 \\
1263,5 \\
1191,4 \\
1518,5\end{array}$ & $\begin{array}{l}8 \\
8 \\
8 \\
8 \\
8 \\
8 \\
7 \\
7 \\
8\end{array}$ & $\begin{array}{l}214,41 \\
168,10 \\
164,64 \\
180,23 \\
216,48 \\
180,50 \\
170,20 \\
189,81\end{array}$ \\
\hline
\end{tabular}

Fonte: DAEE - Banco de Dados Pluviométricos do Estado de São Paulo

Organização: Christiane Spörl 


\section{ÁREA-TESTE 1}

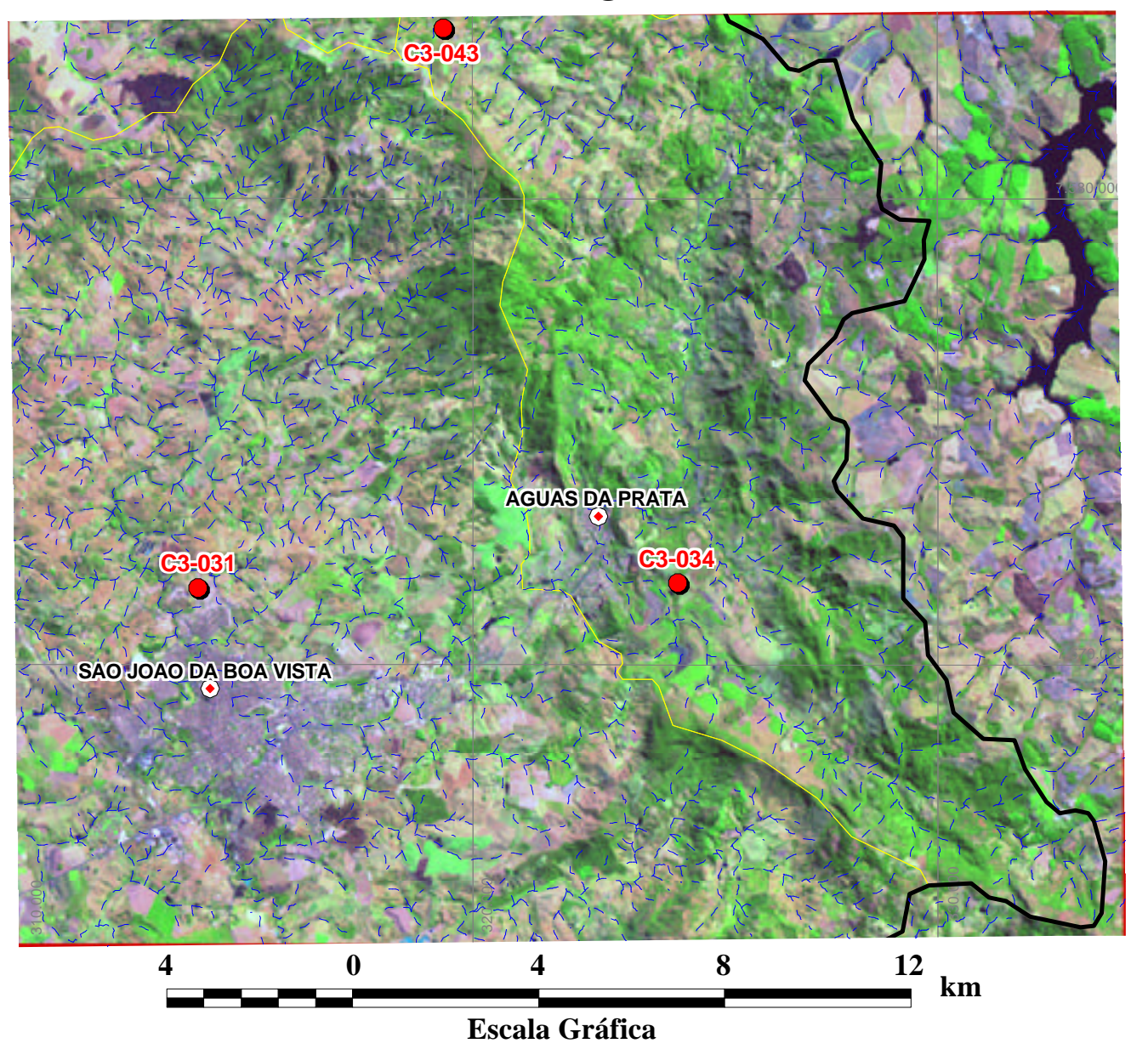

\section{LEGENDA}

- Sede Municipal Limite Municipal

— Limite Estadual

-. Hidrografia

- Postos Pluviométricos

\section{ÁREA-TESTE 2}
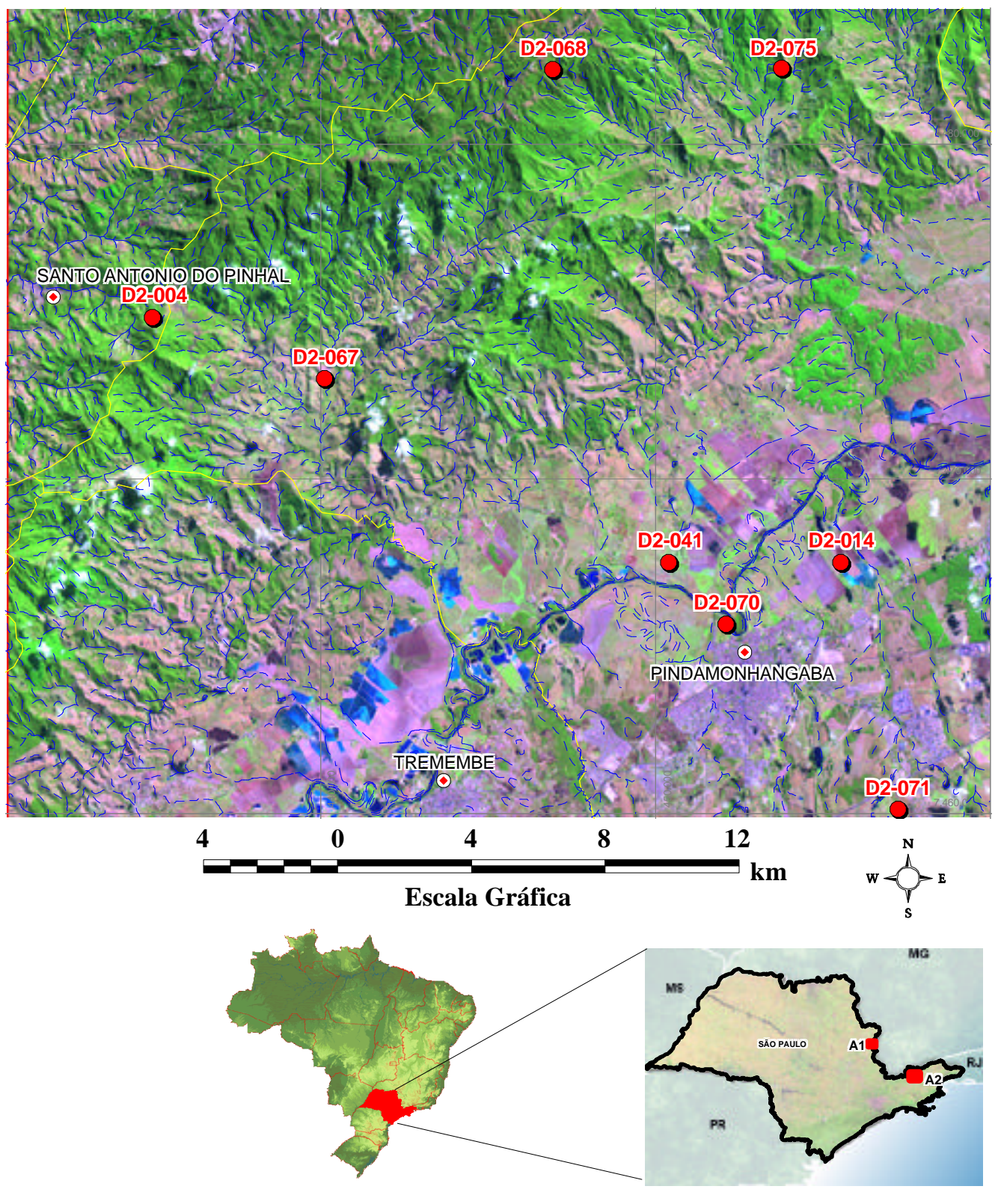

FIGURA 5.1 - LOCALIZAÇÃO DOS POSTOS PLUVIOMÉTRICOS DAS ẢREAS-TESTE 1 E 2 


\section{3 - DesCriçÃo dos PRODUtos CaRTOGRÁficos INTERMEDIÁRIOS GeRADOS}

Além dos mapas básicos gerados foram também confeccionados os mapas intermediários, geomorfológico e uso da terra/cobertura vegetal, os quais fornecem importantes subsídios ao mapeamento síntese da fragilidade ambiental. A seguir são apresentadas as descrições de cada um destes produtos.

\subsection{1 - Mapa Geomorfológico}

A Carta Geomorfológica constitui-se num dos produtos intermediários para a construção da carta de fragilidade. Esta carta é resultante da análise das cartas clinográfica, dos elementos do relevo, de drenagem, das informações geológica e topográfica, dos resultados da interpretação das imagens de satélite, e ainda, das informações obtidas em campo. Tem como objetivo mapear os compartimentos morfoestruturais e morfoesculturais, e suas respectivas formas de relevo.

A metodologia e a técnica de trabalho para a confecção desta carta tiveram como apoio às propostas de Abreu (1982) e Ross (1987, 1992). Foram utilizados como base de informação os padrões de formas com a rugosidade topográfica.

Inicialmente foi realizada a identificação visual dos diversos padrões de formas semelhantes, que se definem pelo aspecto fisionômico da rugosidade topográfica ou das diferentes intensidades dos padrões de dissecação do relevo. Desta forma, a cartografação baseou-se na identificação de "manchas" de padrões de formas de relevo semelhantes entre si.

Em primeiro plano foram cartografadas estas formas de diferentes tamanhos e em planos secundário foram representadas a morfometria, a morfogênese e a morfocronologia que tem vínculo direto com a tipologia das formas.

A cartografação e análise geomorfológica seguiram os pressupostos da metodologia proposta por Ross (1990, 1992), obedecendo a níveis taxonômicos.

O primeiro taxon corresponde às Unidades Morfoestruturais que representam a maior extensão em área e foram identificadas através da imagem de satélite. Na representação cartográfica cada Unidade Morfoestrutural é identificada por uma família de cor.

O segundo taxon refere-se às Unidades Morfoesculturais, as quais estão contidas em cada Unidade Morfoestrutural. Foram também identificadas na imagem de satélite e controladas com investigação de campo. Estas Unidades Morfoesculturais foram representadas pelos tons da família de cor preestabelecidas pelas Unidades Morfoestruturais.

O terceiro taxon representa as Unidades Morfológicas ou Padrões de Formas Semelhantes, as quais estão contidas nas Unidades Morfoesculturais. Estas unidades são definidas por conjuntos de tipologias de formas que guardam entre si elevado grau de 
semelhança quanto ao tamanho de cada forma e ao aspecto fisionômico. Estes padrões são caracterizados por diferentes intensidades de dissecação do relevo, influenciados pelos canais de drenagem, tanto temporários quanto perenes.

Esses Padrões de Formas Semelhantes foram identificados por conjuntos de letras símbolos acompanhados de um conjunto de algarismos arábicos, por exemplo, Dc23. O conjunto de letras identifica a natureza genética dos Padrões de Formas Semelhantes, que podem ser "A" formas de Acumulação, representadas por planícies de diferentes gêneses (marinha, fluvial...) e "D" formas de Denudação, ou seja, esculpidas pelo desgaste erosivo, como morros, serras, etc. Conforme pode ser visto com melhor detalhe no Quadro 5.5.

\section{Quadro 5.5 - Padrões de formas do relevo}

\begin{tabular}{ll}
\hline FORMAS DE DENUDAÇÃO & FORMAS DE ACUMULAÇÃO \\
\hline D - Denudação (erosão) & A - Acumulação (deposição) \\
Da - Formas com topos aguçados & Apf- Formas de planície fluvial \\
Dc - Formas com topos convexos & Apm - Formas de planície marinha \\
Dt - Formas com topos tabulares & Apl - Formas de planície lacustre \\
Dp - Formas de superfícies planas & Api - Formas de planície intertidal (mangue) \\
De - Formas de escarpas & Ad - Formas de campos de dunas \\
Dv - Formas de vertentes & Atf - Formas de terraços fluviais \\
& Atm - Formas de terraços marinhos \\
\hline
\end{tabular}

Fonte: Modificado a partir do tema Geomorfologia do Projeto RADAMBRASIL - MME/DNPM - 1982

A estes conjuntos de letras foram acrescidos algarismos arábicos extraídos da matriz dos índices de dissecação do relevo. Estes números foram obtidos através de medições da dimensão interfluvial média e do entalhamento médio dos vales, conforme apresentado no Quadro 5.6.

Os índices de dissecação do relevo utilizados neste estudo foram adaptados a partir da tabela proposta por Ross (1994), ajustando-se os intervalos de cada classe. Tanto as classes de Entalhamento Médio dos Vales quanto às de Dimensão Interfluvial Média tiveram os valores de seus intervalos recalculados em função da variabilidade das características das áreas-teste. 
Quadro 5.6 - Matriz dos índices de dissecação do relevo

\begin{tabular}{|c|c|c|c|c|c|}
\hline \multirow[b]{2}{*}{$\begin{array}{l}\text { Entalhamento Médio } \\
\text { dos Vales (classes) }\end{array}$} & \multicolumn{5}{|c|}{ Dimensão Interfluvial Média (classes) } \\
\hline & $\begin{array}{c}\text { MUITO } \\
\text { BAIXA } \\
(1) \\
>1250 m\end{array}$ & $\begin{array}{c}B A I X A \\
(2) \\
700 \mathrm{a} \\
1250 \mathrm{~m}\end{array}$ & $\begin{array}{c}\text { MÉDIA } \\
(3) \\
550 \mathrm{a} \\
700 \mathrm{~m}\end{array}$ & $\begin{array}{c}\text { ALTA } \\
(4) \\
400 \mathrm{a} \\
550 \mathrm{~m}\end{array}$ & $\begin{array}{c}\text { MUITO } \\
\text { ALTA } \\
(5) \\
<400 m\end{array}$ \\
\hline $\begin{array}{l}\text { Muito Fraco }(1) \\
(<\text { de } 40 \mathrm{~m})\end{array}$ & 11 & 12 & 13 & 14 & 15 \\
\hline $\begin{array}{l}\text { Fraco }(2) \\
(40 \text { a } 80 \mathrm{~m})\end{array}$ & 21 & 22 & 23 & 24 & 25 \\
\hline $\begin{array}{l}\text { Médio (3) } \\
\text { (80 a 160m) }\end{array}$ & 31 & 32 & 33 & 34 & 35 \\
\hline $\begin{array}{l}\text { Forte (4) } \\
(160 \text { a 300m) }\end{array}$ & 41 & 42 & 43 & 44 & 45 \\
\hline $\begin{array}{l}\text { Muito Forte (5) } \\
(>\text { de } 300 \mathrm{~m})\end{array}$ & 51 & 52 & 53 & 54 & 55 \\
\hline
\end{tabular}

Fonte: Modificado a partir do tema Geomorfologia do Projeto Radambrasil - 1982

Organização: Christiane Spörl

O Quadro 5.6 é uma matriz a qual representa os Índices de Dissecação do Relevo, demonstrando que quanto maior for o valor numérico expresso pelo conjunto dos dois algarismos arábicos, maior é a dissecação e vice-versa. Por exemplo, o conjunto de algarismo 34 representa um menor índice de dissecação do relevo que o conjunto dos algarismos 44 .

A geomorfologia das Áreas-Teste 1 e 2 está apresentada nas Figuras 5.2 e 5.3, respectivamente. 


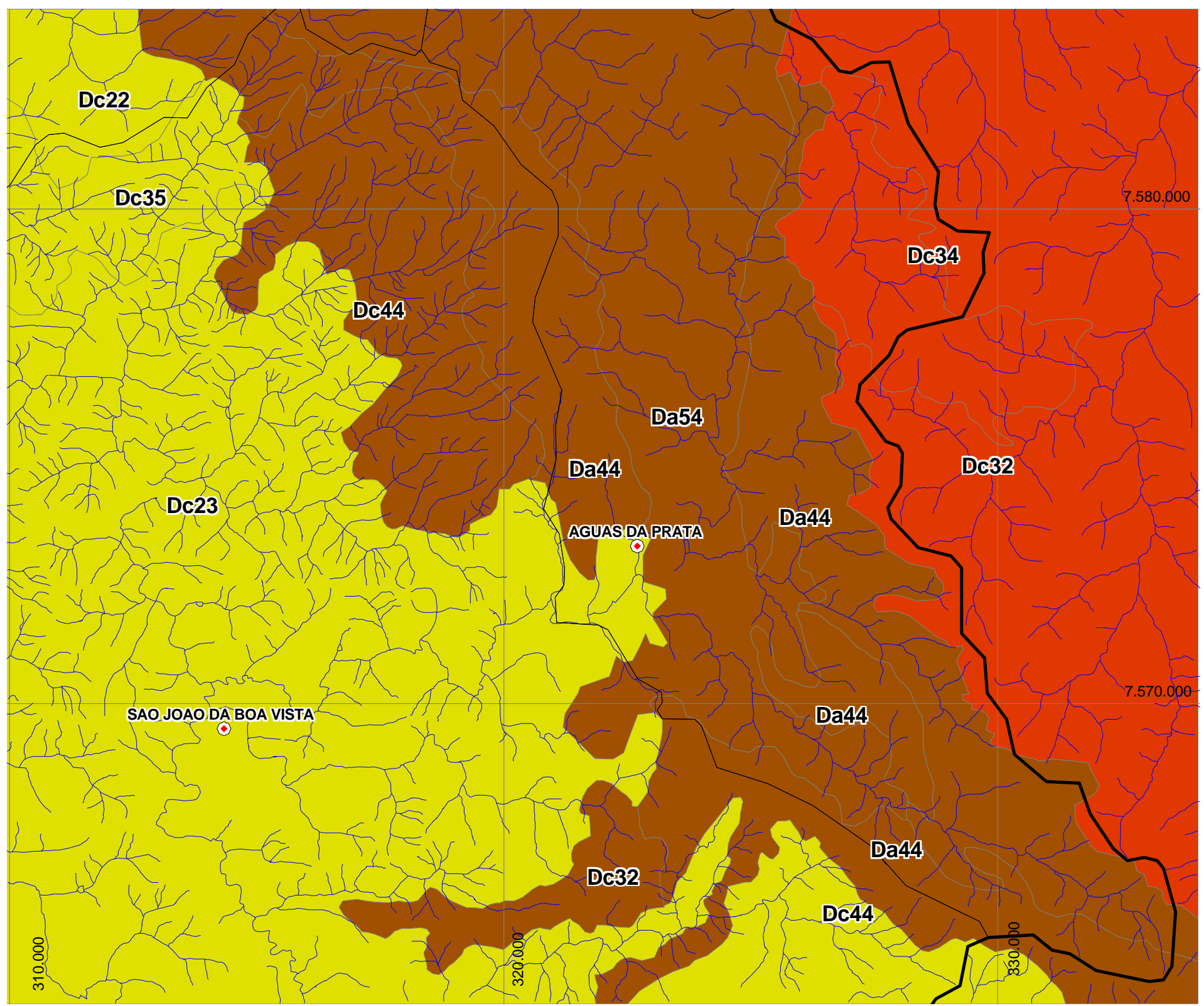

\section{FIGURA 5.2 - GEOMORFOLOGIA ÁREA-TESTE 1}

\section{Morfoesculturas}

Planalto de Poços de Caldas

Planalto de São João da Boa Vista - Águas da Prata

Serras da Borda do Maciço Intrusivo de Poços de Caldas

\section{Formas de Relevo}

- Sede Municipal Limite Municipal Limite Estadual Hidrografia
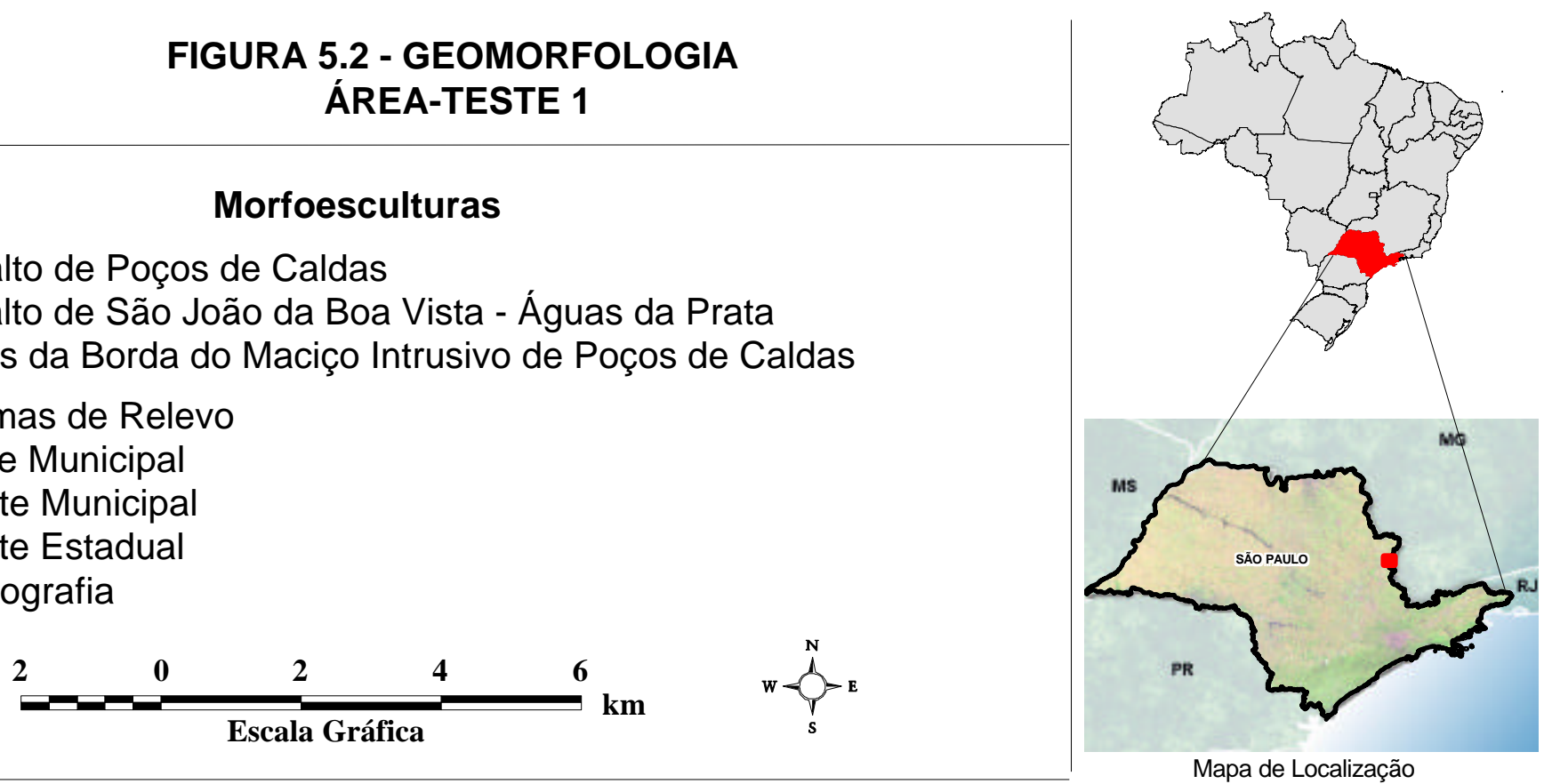


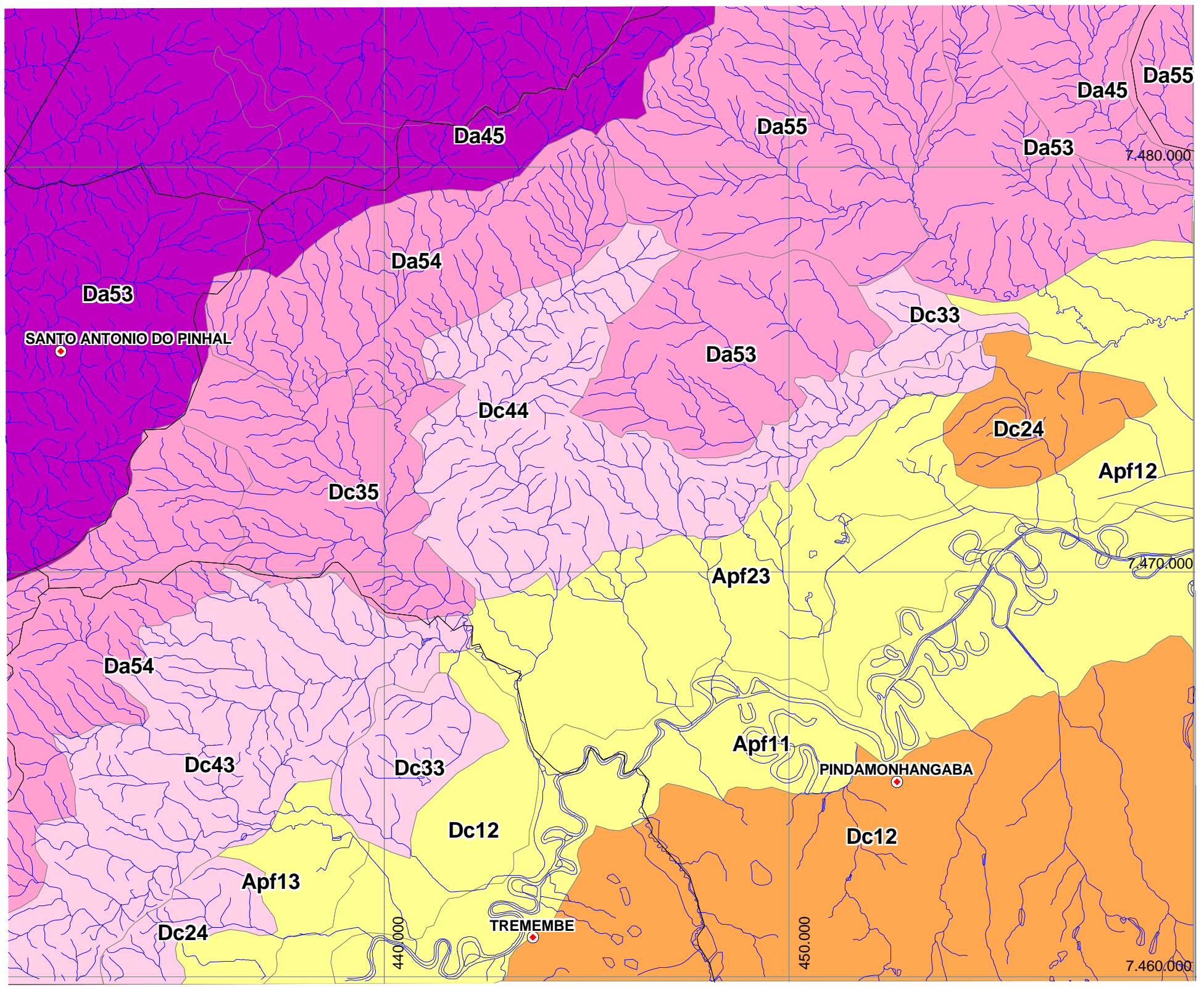

\section{FIGURA 5.3 - GEOMORFOLOGIA ÁREA-TESTE 2}

\section{Morfoesculturas}

Depressão do Médio Paraíba

Pequenas Planícies Fluviais

Planalto do Médio Vale do Paraíba

Planalto e Serra da Mantiqueira

Planalto Paulistano

Formas de Relevo

2 0

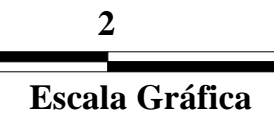

4

$\mathrm{km}$

- Sede Municipal Limite Municipal Hidrografia

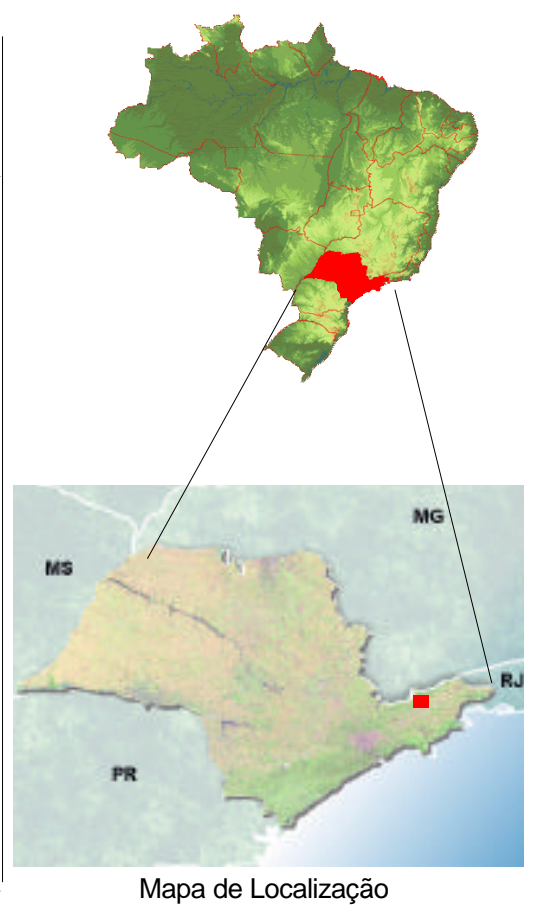




\subsection{2 - Mapa de Uso da Terra/Cobertura Vegetal}

O levantamento do uso da terra é de grande importância, na medida em que os efeitos do uso desordenado causam deterioração no ambiente (ROSS, 1994). Os processos de erosão intensos, as inundações, os assoreamentos de reservatórios e cursos d'água são causas do inadequado uso da terra. Assim, a capacidade de uso da terra pode ser caracterizada como a sua adaptabilidade à intervenção do homem para fins diversos, sem que sofra esgotamento.

Informações atualizadas sobre o uso da terra e sua distribuição são essenciais para o manejo eficiente dos recursos agrícolas, florestais e hídricos. A caracterização do uso da terra contribui para o entendimento da distribuição das principais atividades econômicoprodutivas da região e uma compreensão das inter-relações entre as formas de ocupação e a intensidade dos processos responsáveis pela degradação do meio físico.

O levantamento do uso da terra torna-se, então, um aspecto de interesse fundamental para a compreensão dos padrões de organização do espaço.

Tendo como objetivo produzir um mapa temático de uso e ocupação da terra foram utilizadas as seguintes imagens Landsat 5-TM de 1997: órbita 218/ponto 76, órbita 219/ponto 75, órbita 219/ponto 76. Estas imagens orbitais TM foram tratadas digitalmente, melhorando-se a qualidade visual para a extração de informações. Dessa forma, as imagens foram preparadas para análise e classificação digital.

Estas imagens foram georreferenciadas utilizando como base as folhas topográficas do IBGE na escala 1:50.000. Os dados foram processsados no software SPRING 4.1.

O processo de interpretação digital da imagem Landsat TM-5 foi iniciado com a análise das melhores combinações de bandas para o estudo do uso da terra. Destas composições foi selecionada a composição colorida em RGB com as bandas 5, 4 e 3 do TM, respectivamente (banda 5 no canal vermelho-R, banda 4, no verde-G e banda 3 no azulB). Esta composição apresenta um colorido equivalente às cores percebidas pelo olho humano servindo como ponto de partida para uma primeira análise visual das diversas formas de ocupação do solo.

Depois do tratamento digital da imagem iniciou-se o processo de classificação multiespectral para obtenção do mapa de uso e ocupação da terra.

Na etapa de classificação temática de uso da terra foi aplicada a classificação digital supervisionada, desenvolvida em função do conhecimento prévio de áreas amostrais obtidas no trabalho de campo, o que permitiu a seleção de áreas de treinamento confiáveis, as quais foram utilizadas para treinar o algoritmo classificador de máxima verossimilhança.

Primeiramente para a coleta das amostras de treinamento identificou-se na imagem Landsat (composição colorida) áreas representativas de cada classe. Desta forma, foram 
delimitadas áreas homogêneas (amostras) para o reconhecimento dos padrões das classes de uso. O programa, por métodos estatísticos, classificou todos os pixels que tinham o mesmo padrão da amostra. Em seguida foram criadas as assinaturas espectrais das categorias, resultando no mapa de uso e ocupação da terra.

Os padrões mapeados foram os mais representativos dentro das possibilidades da escala de interpretação adotada, levando-se em consideração as diferentes capacidades de proteção fornecidas ao solo por cada tipo de uso: agricultura ciclo curto, arroz irrigado, café, mata, pastagem, porto de areia e reflorestamento.

Sobre as imagens classificadas foi feita uma pós-classificação, que consiste na uniformização de temas, ou seja, eliminar pontos isolados, classificados diferentemente de sua vizinhança. Conseqüentemente, gerou-se uma imagem classificada com aparência menos "ruidosa". O resultado desta classificação foram os mapas de uso e ocupação da terra das áreas-teste 1 e 2, já apresentados no Capítulo 3 nas Figuras 3.5 e 3.9. 